Historic, Archive Document

Do not assume content reflects current scientific knowledge, policies, or practices. 




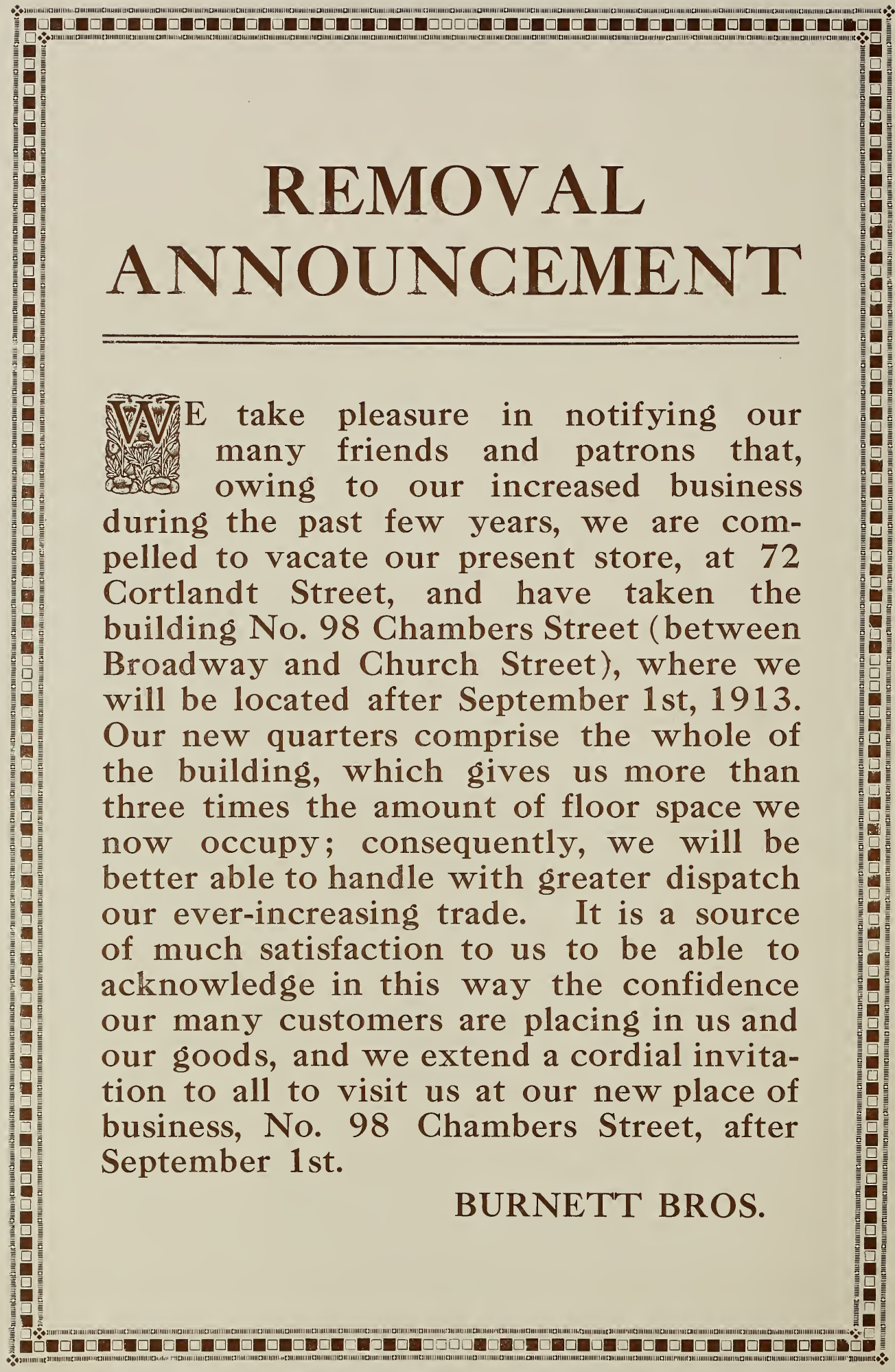




\section{LILY OF THE VALLEY}

Ready for delivery in November

Lily of the Valley is extensively grown for cut flowers for Winter use. They are forced in large quantities and being perfectly hardy can also be grown in shaded locations in borders or under trees, where they will bloom early in the Spring. The flowers, which are bellshaped and of the purest white color, are highly prized for cutting purposes.

NOTE. We make a specialty of Valley and import absolutely the rery finest pips grown, all extra large, firm and robust, with long, fibrous roots which when forced are certain to give satisfaction.

\section{VALLEY PIPS}

Burnett's Selected

Doz.

100

1000

$\begin{array}{lll}\text { Dresden Brand } \$ 0.40 & \$ 2.75 & \$ 20.00\end{array}$

Extra Choice Ber-

lin

Strong Hamburg.

Giant Late Flower-

ing
$.30 \quad 2.00$

.30

$.35 \quad 2.50$

$2.25 \quad 15.00$

\section{VALLEY CLUMPS}

Excellent for naturalizing or outdoor planting in shaded positions. The clumps we offer are extra large, with an abundance of flowering pips which will produce a mass of bloom.

Extra Large Selected Clumps: Each, 35c.; doz., $\$ 3.50 ; 100, \$ 25.00$.

\section{LILY OF THE VALLEY (COLD STORAGE)}

The demand for COLD STORAGE VALLEY PIPS becoming greater every year, we are now prepared at all times to supply our customers promptly with our SELECTED DRESDEN BRAND at the following prices:

Price per case of $250, \$ 7.00 ; 500, \$ 13.00 ; 1,000, \$ 25.00 ; 2,000, \$ 45.00$.

\section{IMPORTANT NOTICE}

To Those Requiring the Services of a Superintendent, Head Gardener or Assistant

We have at all times on our register the names of competent men who are open for such positions, and will be careful to recommend only such as would be most suitable and with first-class references.

\section{TO GARDENERS WISHING POSITIONS}

We constantly have calls for first-class gardeners, and to supply such openings we cheerfully ask those who are in want of a position to apply to us, and we will endeavor to find a suitable place for them. We positively make no charge for this service, either to employer or employee.

BURNETT BROS. give no warranty, express or implied, as to description, quality, productiveness, or any other matter of any seeds, bulbs or plants they send out, and they will not be in any way responsible for the crop. If the purchaser does not accept the goods on these terms, they are at once to be returned.-B. BROS.

\section{BURNETT BROTHERS SEEDSMEN}




\section{BURNETT BROS.'}

\section{RELIABLE BULBS AND ROOTS}

FOR FORCING AND OUTDOOR PLANTING

All bulbs sent out by us are true to name, of the largest size, and selected only from those sorts which are the cream of the Holland market.

Therefore, they should not be confounded with the small-sized, low-priced mixtures usually sold.

\section{HYACINTHS}

\section{Early French Roman Hyacinths}

White Roman Hyacinths are extensively grown for forcing purposes. The flowers are pure white, delightfully fragrant, and each bulb will throw up from three to four spikes. For forcing, three or four bulbs are generally planted in a pot, in good soil. The pots should be kept in a cool dark place until they fill with roots. They are very easily grown and by making successive plantings may be had in flower all through the Winter.

\begin{tabular}{|c|c|c|c|}
\hline & Doz. & 100 & 1000 \\
\hline $\begin{array}{l}\text { Pure White } \\
\text { ster Bulbs }\end{array}$ & $\$ 1.00$ & $\$ 6.00$ & $\$ 55.00$ \\
\hline Mammoth Bui & .75 & 5.50 & 50.00 \\
\hline $\begin{array}{l}\text { Selected Bulbs, } 13-15 \mathrm{ctm} . \\
\text { Selected Bulbs, } 12-15 \mathrm{ctm} .\end{array}$ & $\begin{array}{l}.60 \\
.50\end{array}$ & $\begin{array}{l}4.50 \\
4.00\end{array}$ & $\begin{array}{l}40.00 \\
35.00\end{array}$ \\
\hline
\end{tabular}

\section{Italian Hyacinths}

Largely grown for cutting purposes. The flowers are single, very graceful and fragrant. They are hardier than the Romans, and may be planted , outsing outside in the Fall for early Spring cutting.

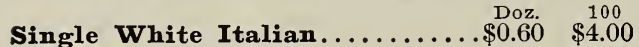

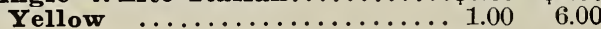

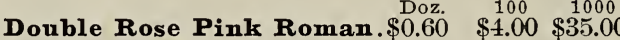

Double Dark Rose Roman $.60 \quad 4.00 \quad 35.00$

Single Blue Roman...... . .50 3.75

Single Yellow Roman.... $.75 \quad 5.00$

\section{Miniature Hyacinths}

Also known as Dutch Roman, or Pan Hyacinths. Suitable for growing in groups, pots or earthen pans. Perfectly hardy.

Pure White, Cream White, Dark

Red, Rosy Red, Light Blue and

Dark Blue, separate colors......\$0.50 $\$ 3.00$

Mixed, All Colors............. .40 2.50

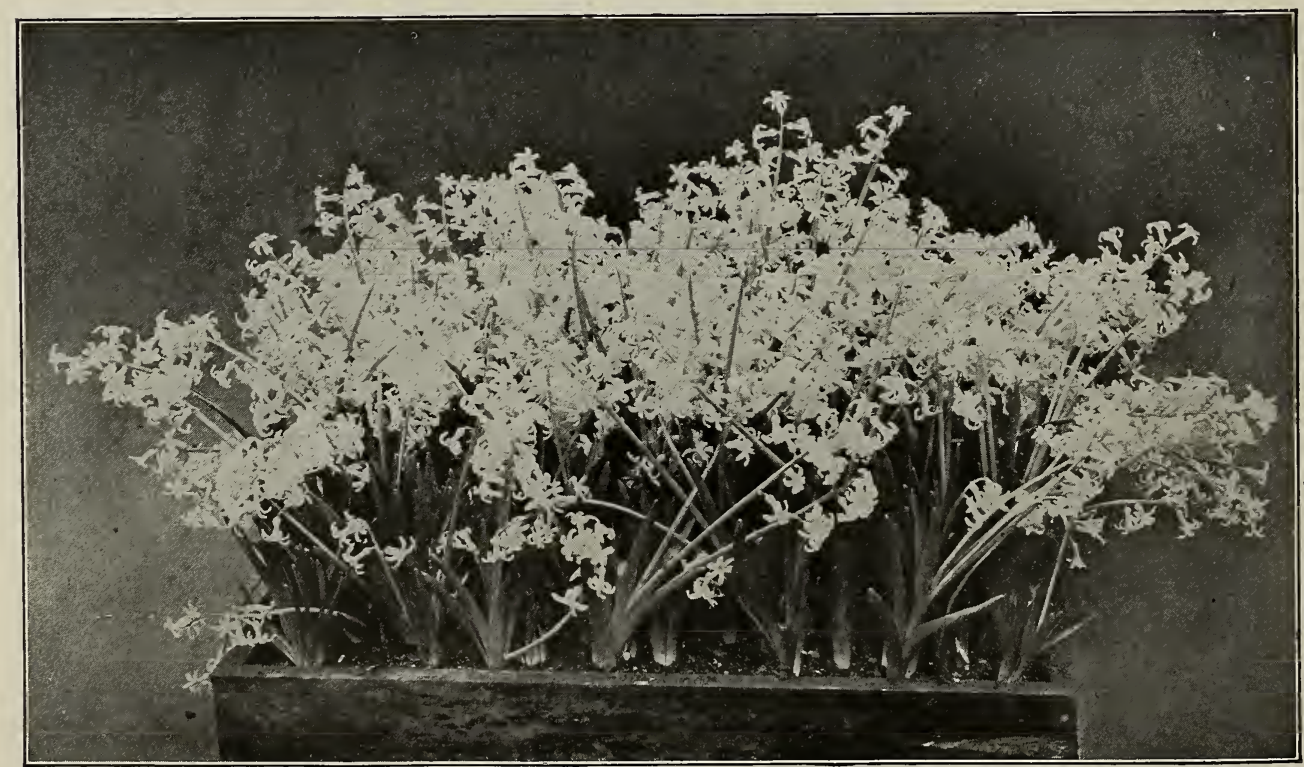

Early French Roman Hyacinths 


\section{Named Dutch Hyacinths}

Cultural Directions for Growing in Pots. Select heavy bulbs and plant as early as possible, using a six-inch pot for a single bulb. Fill the pots with light, rich potting soil, leaving the top of the bulb just above the surface; give a good watering and set away in a cool place, covering them with about five inches of sand or ashes. In about six weeks they may be taken to the room in which they are to flower. By bringing in a few pots about two weeks apart a succession of bloom may be had during Winter.

Cultural Directions for Planting in the Open Ground. October and November is the proper time, but they can be set out any time as long as the ground remains open. The beds should be well dug to a depth of about 14 inches, and raised from two to four inches above the level of the walks. The bulbs should be planted evenly about six inches deep, and from five to six inches apart. Care must be taken to press the earth firmly around the bulbs, setting each bulb in a handful of sand, to insure drainage.

Cultural Directions for Growing in Glasses. Single Hyacinths do best in glasses, as they produce a much larger spike. Place the bulb in a glass, which should be filled with water so it touches the bottom of the bulb; then put away in a cool place, or on a shelf in the dark part of the cellar, for from six to eight weeks, changing the water every two weeks; then remove them to the light, and place in a cool room with even temperature and they will produce very fine spikes and remain in bloom a long time. A small piece of charcoal in the water is beneficial.

\section{Single Varieties for Forcing in Pots and Glasses}

\section{PURE WHITE AND BLUSH}

Alba Superbissima. Clear white. Baroness von Thuyll. Snow white.

Blanchard. Pure white, large spike.

Grandeur a Merveille. Blush white.

La Franchise. Creamy white, fine spike.

La Grandesse. Pure white, large spike, the best white. Each 20c., doz. $\$ 2.00$.

Madam Van der Hoop. Large, pure white. I'Innocence. Pure white.

Voltaire. Blush white, large bells.

\section{RED, CRIMSON AND PINK}

Amy. Bright, dark red.

General Pelissier. Deep crimson, early.

Gertrude. Rosy pink, large truss.

Gigantea. Delicate rose, large spike.

Lord Macaulay. Bright red.

Moreno. Bright pink, large truss.

Norma. Delicate pink; fine.

Robert Steiger. Deep crimson.

Roi des Belges. Scarlet, fine truss.

Rosalia. Carmine pink; extra.

Von Schiller. Dark red, large spike.

\section{BLUE, LILAC AND MAUVE}

Baron von Thuyll. Violet blue, large spike. Bleu Mourant. Purple blue.

Blondin. Porcelain blue, early.

Charles Dickens. Deep blue, shaded.

Czar Peter. Light blue; fine. Each 20c., đoz. $\$ 2.00$.

Grand Lilas. Porcelain lilac, fine truss.

Grand Maitre. Deep porcelain blue; extra fine. King of the Blues. The best dark blue.

La Peyrouse. Porcelain blue.

Leonidas. Clear porcelain blue.

Marie. Dark blue, fine spike.

Queen of the Blues. Large light blue.

Regulus. Light blue, large spike.

\section{YELLOW AND ORANGE}

Alida Jacoba. Dark, medium early.

Anna Carolina. Pure yellow.

Hermann. Orange, large bells.

King of the Yellows. Fine deep yellow.

La Citronniere. Bright citron, fine.

Ida. Large yellow, early.

Prince of Orange. Orange.

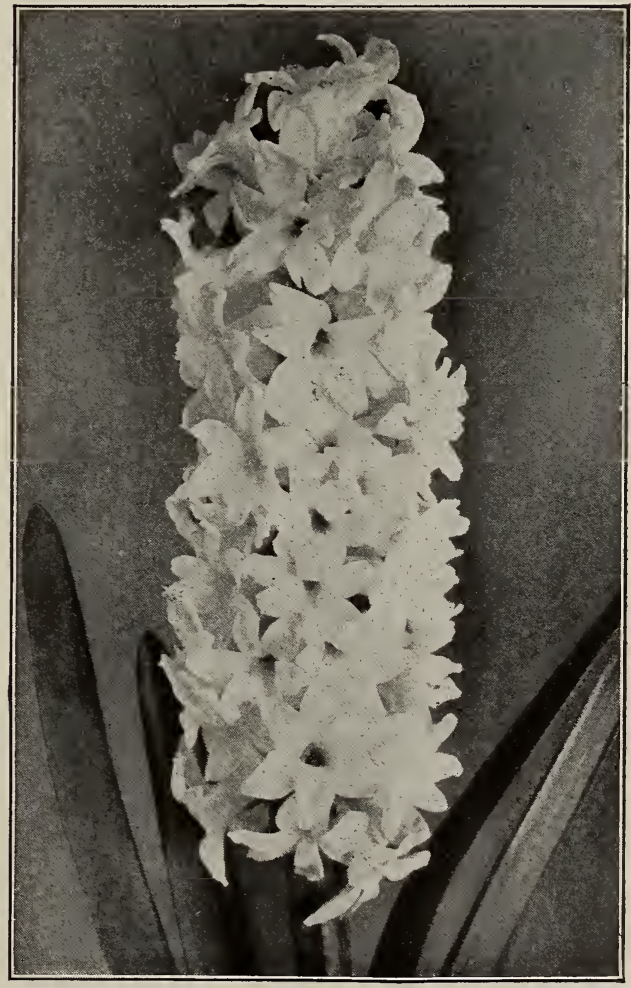

Hyacinth La Grandesse

All the above varieties where not priced: Each 15c., doz. \$1.75, $100 \$ 12.00$. 


\section{Double Named Hyacinths} DOUBLE RED

Bouquet Royal. Rose, dark eye. Bouquet Tendre. Crimson. Czar Nicholas. Delicate rose.

Lord Wellington. Double pink, large. Noble par Merite. Deep rose, fine truss. Princess Alexandra. Deep rose, large bells.

\section{DOUBLE WHITE}

Anna Maria. Blush, purple eye. Bouquet Royal. Pure white.

La Tour d'Auvergne. Snow white; fine. La Virginite. Pale blush, fine spike.

Prince of Waterloo. Pure white, large truss. Princess Alice. Snow white.

\section{DOUBLE BLUE}

Bloksberg. Porcelain blue, large truss. Crown Prince of Sweden. Lavender. Garrick. Deep blue, good truss. General Antinck. Light blue; extra. Lord Raglan. Dark blue, large spike. Prince of Saxe Weimar. Dark blue.

\section{DOUBLE YELLOW}

Bouquet d'Orange. Deep orange; fine. Goethe. Pale yellow; large bells. Jaune Supreme. Canary yellow; fine. Louis d'Or. Yellow, dark center. Ophir d'Or. Yellow, purple center.

All the above varieties: Each 15c., doz. $\$ 1.75,100 \$ 12.00$.

\section{Burnett's Selected Dutch Hyacinths}

\section{For Bedding and Forcing}

These bulbs are all extra large, solid and true to color.

\section{SINGLE VARIETIES}

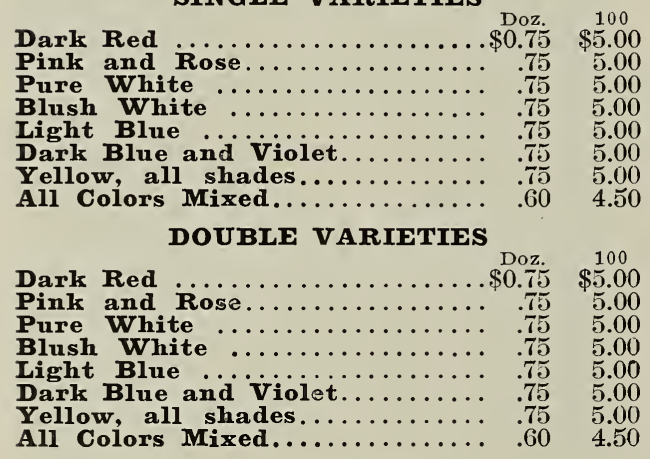

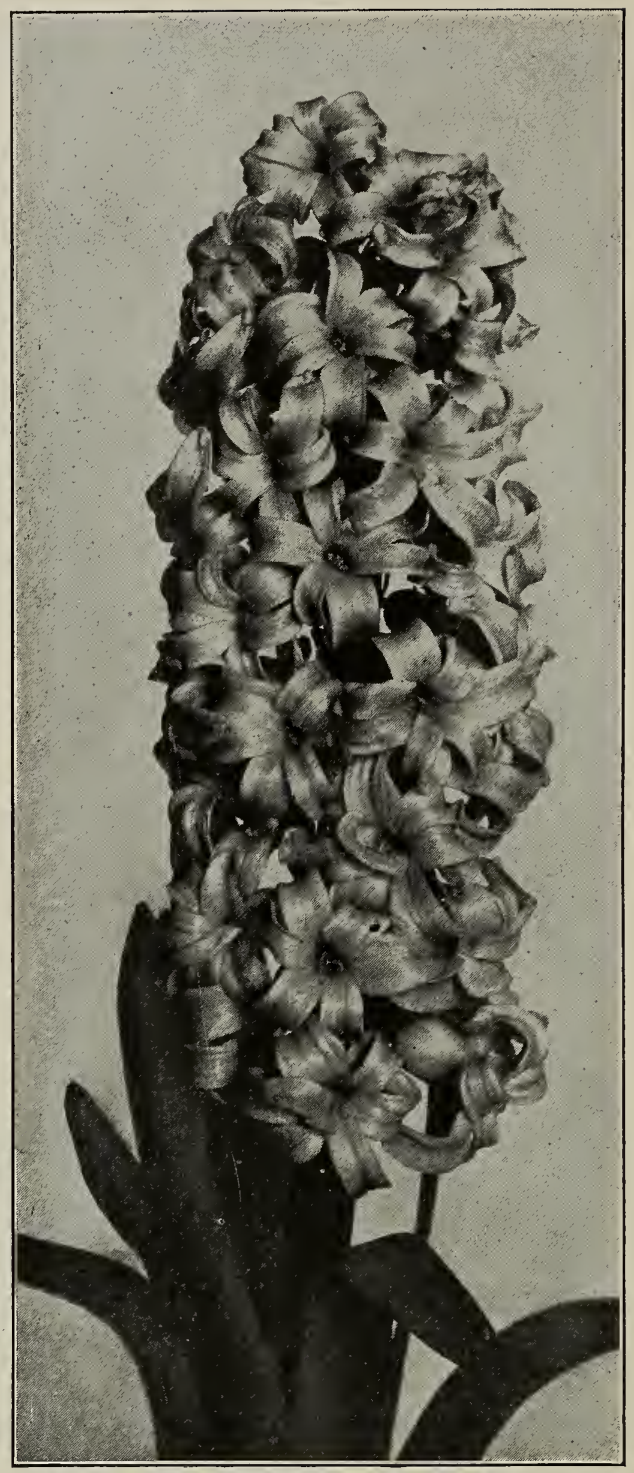

Burnett's Selected Bedding Hyacinth

\section{Burnett's Special Dutch Hyacinths}

These are all good-sized bulbs and will produce large spikes of bloom.

\section{SINGLE VARIETIES}

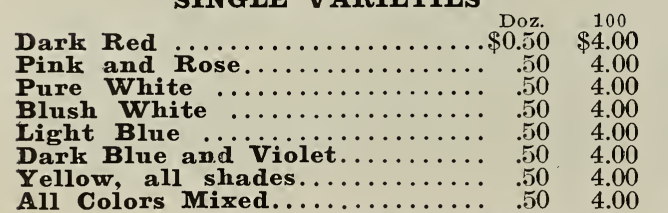

DOUBLE VARIETIES

Dark Red $\ldots \ldots \ldots \ldots \ldots \ldots \ldots \ldots \ldots . \$ \ldots 0.50 \quad \$ 4.00$

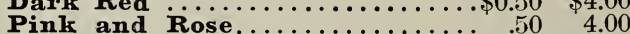

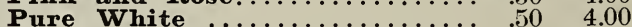

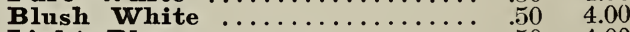

Light Blue ..................... $\quad .50 \quad 4.00$

Dark Blue and Violet......... .50 4.00

Yellow, all shades............ .50 4.00

All Colors Mixed................

MISCELLANEOUS HYACINTHS, see page 11 . 


\section{TULIPS}

The Tulip is the most popular of all Spring-flowering bulbs. Their brilliancy of coior, beauty of form and gorgeous shades render them the most elfective of all bulbous nlants for bedding and planting in groups or borders. For pot culture and forcing for Winter flowers several varieties are invaluable. Plant outside in October or November about four inches deep and four inches apart. 'The soil should be well dug and a liberal supply of well-rotted manure applied.

Varieties prefixed by an asterisk (*) are the best for forcing.

\section{Single Duc Van Thol Tulips}

Duc van Thol Tulips are of dwarf habit, growing only about six inches, and are generally used for forcing and pot culture.

$\begin{array}{rrr}\text { Crimson. Bright crimson, showy... } \$ 0.30 & \$ 2.00\end{array}$

Red and Yellow................ .30 2.00

Rose. Milky white, shading to rose.. $\quad .50 \quad 3.00$

Scarlet. Dazzling reddish scarlet... $.30 \quad 2.00$

Yellow. Citron yellow.......... .50 3.50

White. Clear satiny white....... $.40 \quad 2.50$

\section{Burnett's Special Single Mixed Tulips}

This mixture contains an equal proportion of the leading named sorts blended by ourselres; therefore they can be relied upon to give satisfactory results. Doz. 25 c., $100 \$ 1.50,1000 \$ 10.00$.

\section{Single Named Tulips}

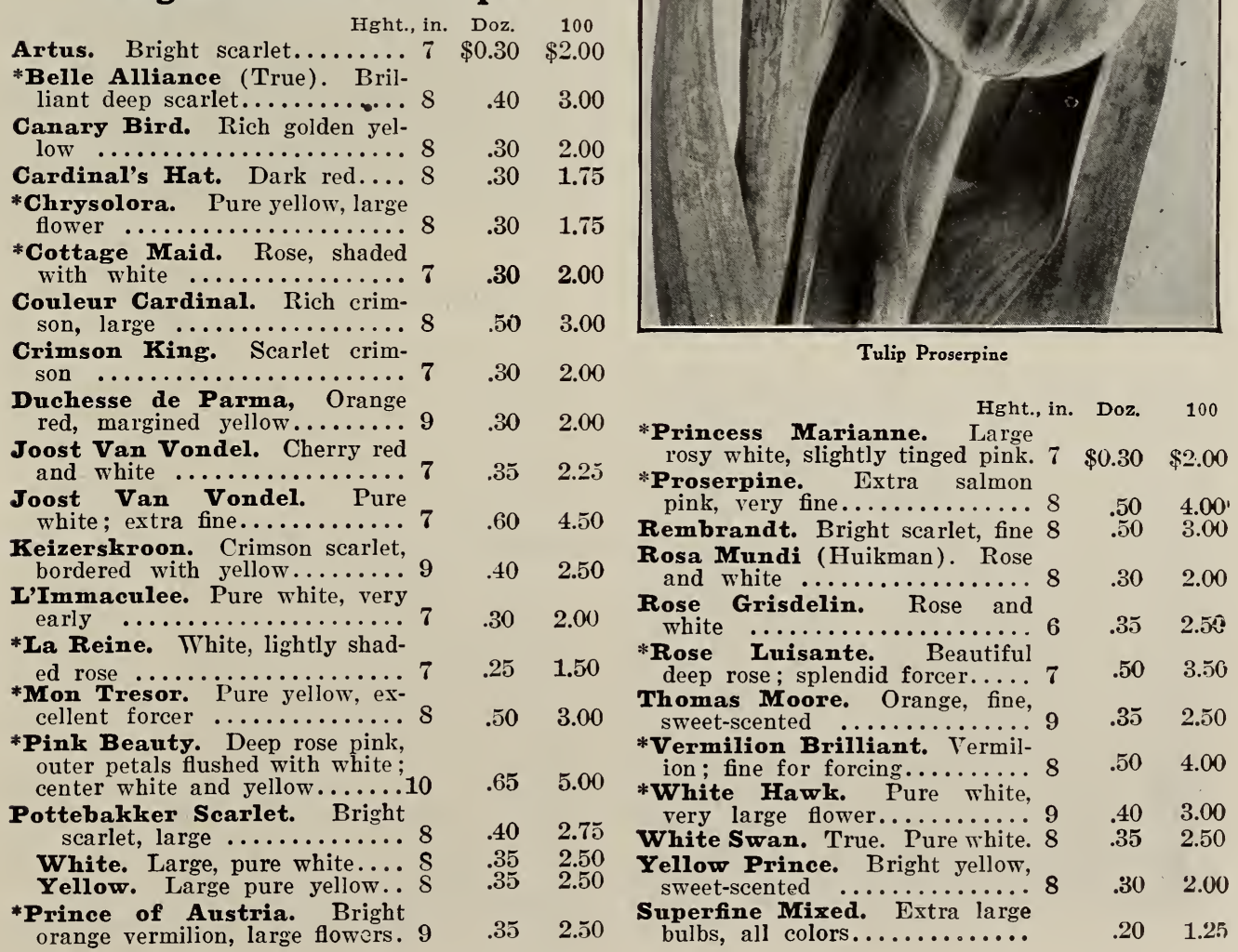




\section{Double Named Tulips}

Double Tulips are largely used for outside planting. While not as early as the single varieties, they will be found very effective for designs, etc., as they remain in bloom much longer than the single sorts.

Hght. in. Doz. 100

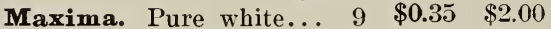

Couronne d'Or. Yellow, orange shaded; excellent forcer. $10 \quad .50$

Duc Van Thol. Red and yellow $\quad \ldots \ldots \ldots \ldots \ldots \ldots \ldots, 6 \ldots \ldots$

$\begin{array}{lllll}\text { Duc Van Thol. Carmine.... } & 6 & .30 & 2.00\end{array}$

Duke of York. Rose, bordered

white ................... $10 \quad .30 \quad 2.00$

$\begin{array}{llll}\text { Helianthus. Yellow and scarlet. } & 9 & .50 & 3.00\end{array}$

Imperator Rubrorum. Bright

scarlet $\ldots \ldots \ldots \ldots \ldots \ldots \ldots \ldots \quad 8 \quad .50 \quad 3.00$

La Candeur. Pure white, excellent for beds............ $5 \quad .30 \quad 2.00$

$\begin{array}{llll}\text { Murillo. Pink blush, shaded.. } & 6 & .50 & 3.00\end{array}$

Rose d'Amour. Pale flesh color extra fine .............. 10

Rex Rubrorum. Bright red, large and showy...........

Rubra Maxima. Deep red...

Salvator Rosa. White flamed deep rose; splendid forcer....

Tournesol. Red and yellow.. 8

Tournesol. Orange yellow.... 8

Yellow Rose. Bright yellow. 6

Burnett's Special Mixed.

Extra large bulbs..........

\section{Parrot or Dragon Tulips}

These belong to the late or May-flowering type, and have immense flowers of singular form and brilliant colors. Petals curiously fringed.

Amiral de Constantinople. Large red flowers, tipped orange.......\$0.50 $\$ 3.00$

Cramoisie Brilliant. Deep crimson, with black star-shaped center.. $\quad .50$

Markgraaf van Baden. Yellow, striped with scarlet and green.... .50

Lutea Major. Large, bright yellow. .50

Perfecta. Yellow, striped red...... $.50 \quad 3.00$

Choice Mixed, All Colors....... . .35 2.50

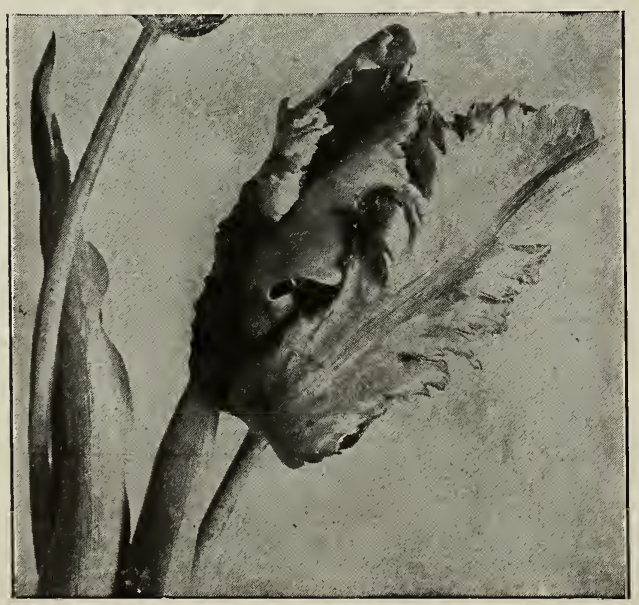

Parrot Tulips

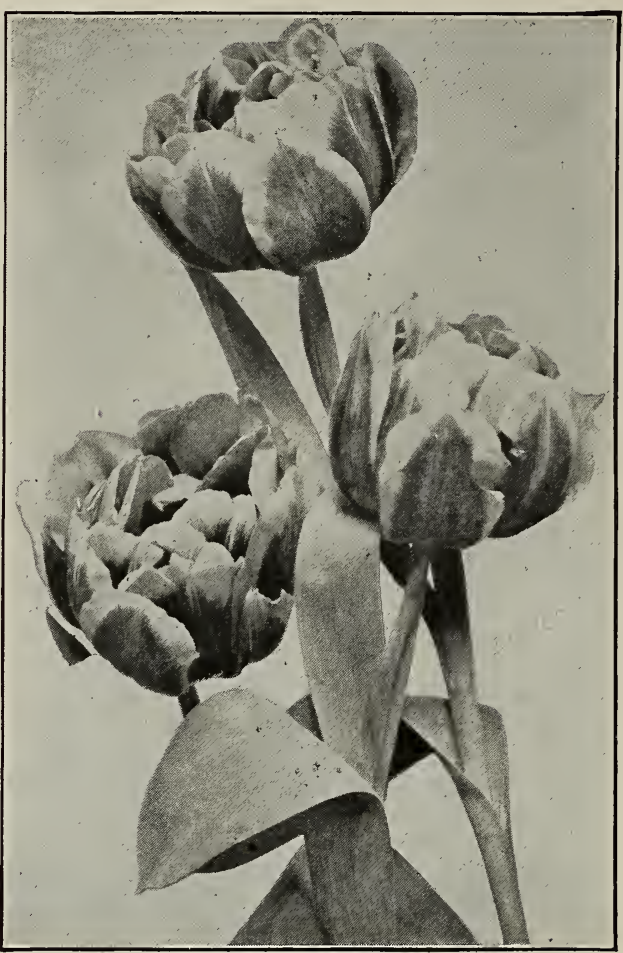

Double Tulip Tournesol

\section{Miscellaneous Tulips Late or May Flowering}

These Tulips are very showy, and generally grown for exhibition purposes, the color and markings being very beautiful.

Bizarres. Yellow ground witk red

or white markings.............. \$0.30 $\$ 2.00$

Bouton d'Or. Pure yellow......... $40 \quad 2.50$

Breeders' Choice Mixed. These Tulips contain a beautiful collection of colors and markings not found in other varieties................

Byblømens. White ground, lilac or black markings ................

Gesneriana Lutea. Pure yellow..

Gesneriana (true). Scarlet, blue

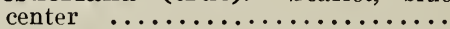

Golden Crown. Yellow, red bordered..$\ldots \ldots \ldots \ldots \ldots \ldots \ldots$.

Isabella (Shandon Bells). Salmon

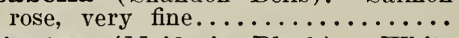

Picotee (Maiden's Blush). White rose, shaded ................... Sulphur Crown. White, rose bor-

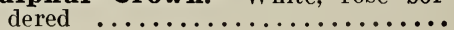

$.40,2.00$

$.35 \quad 2.00$

$.30 \quad 3.00$

$.35 \quad 2.25$

$.30 \quad 1.50$

$.40 \quad 2.25$

$.30 \quad 2.00$

$.40 \quad 2.50$ 


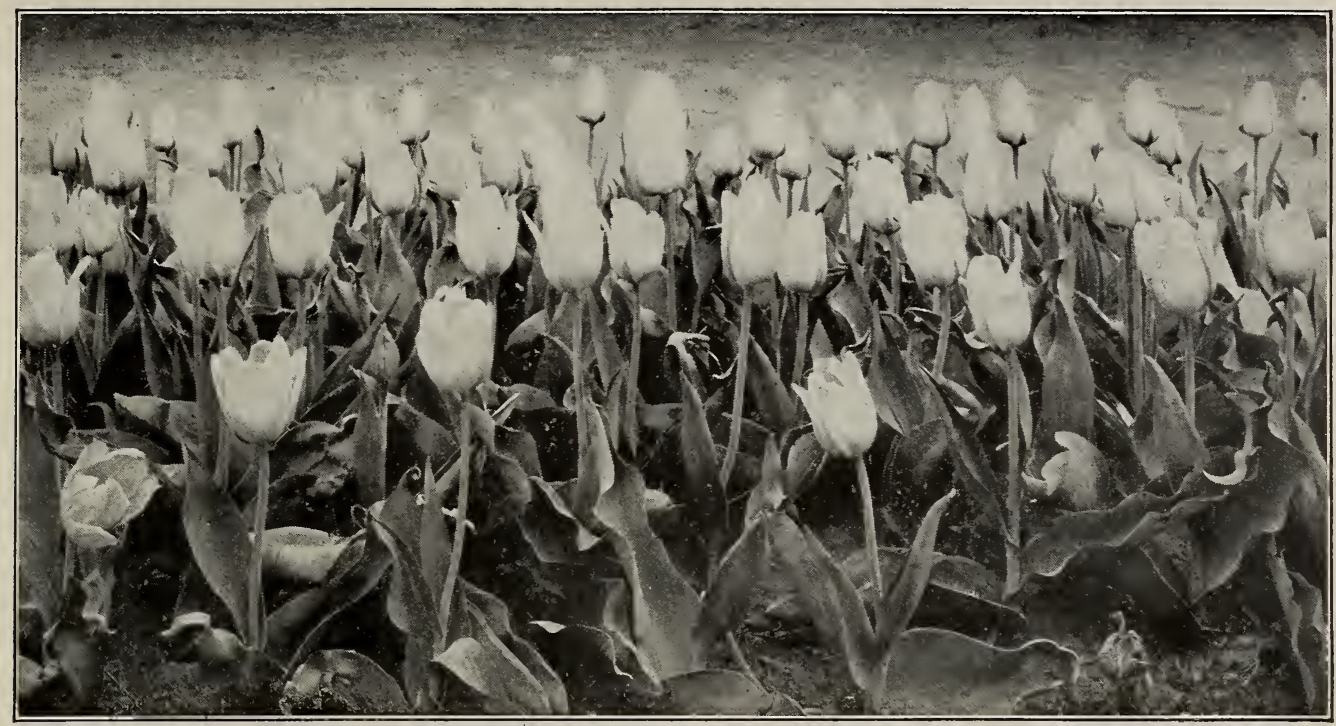

\section{DARWIN TULIPS}

\section{Single Late or May Flowering. The grandest Tulips in existence}

This magnificent class is considered to be the finest of the Tulip race, and is becoming more popular every year.

Having many advantages over the older and better known varieties, blooming about four weeks later with massive leaves and long, strong stems from two to three feet in length, supporting the most handsome globe-shaped flowers it is possible to imagine, in every variety of color and shade from the most delicate blue and blush pink, to rose, scarlet, crimson, violet, brown and black, etc.

They are excellent for late forcing, and wherever early Spring cut flowers are desired they are unsurpassed, being especially effective in vases. They also make a brilliant display when planted in masses in the shrubbery border or in herbaceous beds.

In fact, every lover of the beautiful should not fail to include at least some of these Tulips for Fall planting. The following list we consider to be the best varieties offered and will undoubtedly give satisfaction.

Baron de la Tonnaye. Lively rose, Doz. 100 tinged blue ............... $\$ 0.50 \$ 4.00$

Bartigon. Brilliant red; very fine.. $.65 \quad 5.00$

Clara Butt. Soft, delicate, salmon rose ; beautiful .................

Early Dawn. Rose, self-colored.... .60

Europe. Bright carmine scarlet..... .75

Faust. Dark intense violet....... 1.25

Farncombe Sanders. Dark brilliant crimson ....................... 1.00

Flora's Feast. Violet rose ; fine.... . .60

Gretchen. Blush pink.......... 40

Glow. Brilliant dark red; bold flower .60

Harry Veitch. Dark brownish red.. .60

Inglescombe Scarlet. Brilliant

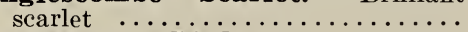

Inglescombe Pink. Beautiful salmon rose ................... .40

Inglescombe Yellow. Pure yellow. 1.00

Kate Greenaway. White, lilac shaded; very late ...............

La Candeur. (Snowdown). Pure white $\ldots \ldots \ldots \ldots \ldots \ldots \ldots \ldots$

Loveliness. Soft rosy carmine.....

Mahony. Brownish red..............

Maiden Blush. Rose, extra.......

May Queen. Bright soft rose, center Cambridge blue with white

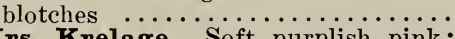

Mrs. Krelage. Soft purplish pink; extra $\ldots \ldots \ldots \ldots \ldots \ldots \ldots \ldots \ldots . .50$
Mrs. Potter Palmer. Dark violet; Doz. 100 handsome flower .............. \$0.50 \$4.00

Nora Ware. Lilac, shaded white.. $.60 \quad 4.00$

Painted Lady. Creamy white; large

flower .................... .50 4.00

Pride of Haarlem. Deep salmon rose, shaded scarlet . . .......... $60 \quad 400$

Psyche. Delicate light pink.......... $1.00 \quad 7.50$

Queen of Roses. Lilac red; charm-

ing .................... $50 \quad 4.00$

Rev. Ewbank. Heliotrope, light blue edge; magnificent ............ .85 6.50

Salmon King. Bright carmine red; extra ..................... $50 \quad 4.00$

The Sultan. Superb glossy black... $\quad .50 \quad 3.50$ White Queen. Soft white, slightly tinged with blush; fine.......... .75 5.50

7.50 Zulu. Deep violet; large flower.... $1.25 \quad 10.00$ Darwin. Superfine Mixed.......... $.40 \quad 2.50$

Double Late Flowering Tulips

4.00 Pæony Gold. Red, gold striped.... $\$ 0.40 \$ 3.00$ Pæony Red. Deep red; bold flower. $.40 \quad 3.00$ Rose Pompon. Pink and white; fine $\quad .50 \quad 3.50$ $\begin{array}{lllll}5.00 & \text { Blue Flag. Violet blue; extra.... } .40 \quad 3.00\end{array}$ 4.00 Mariage de ma Fille. White, 


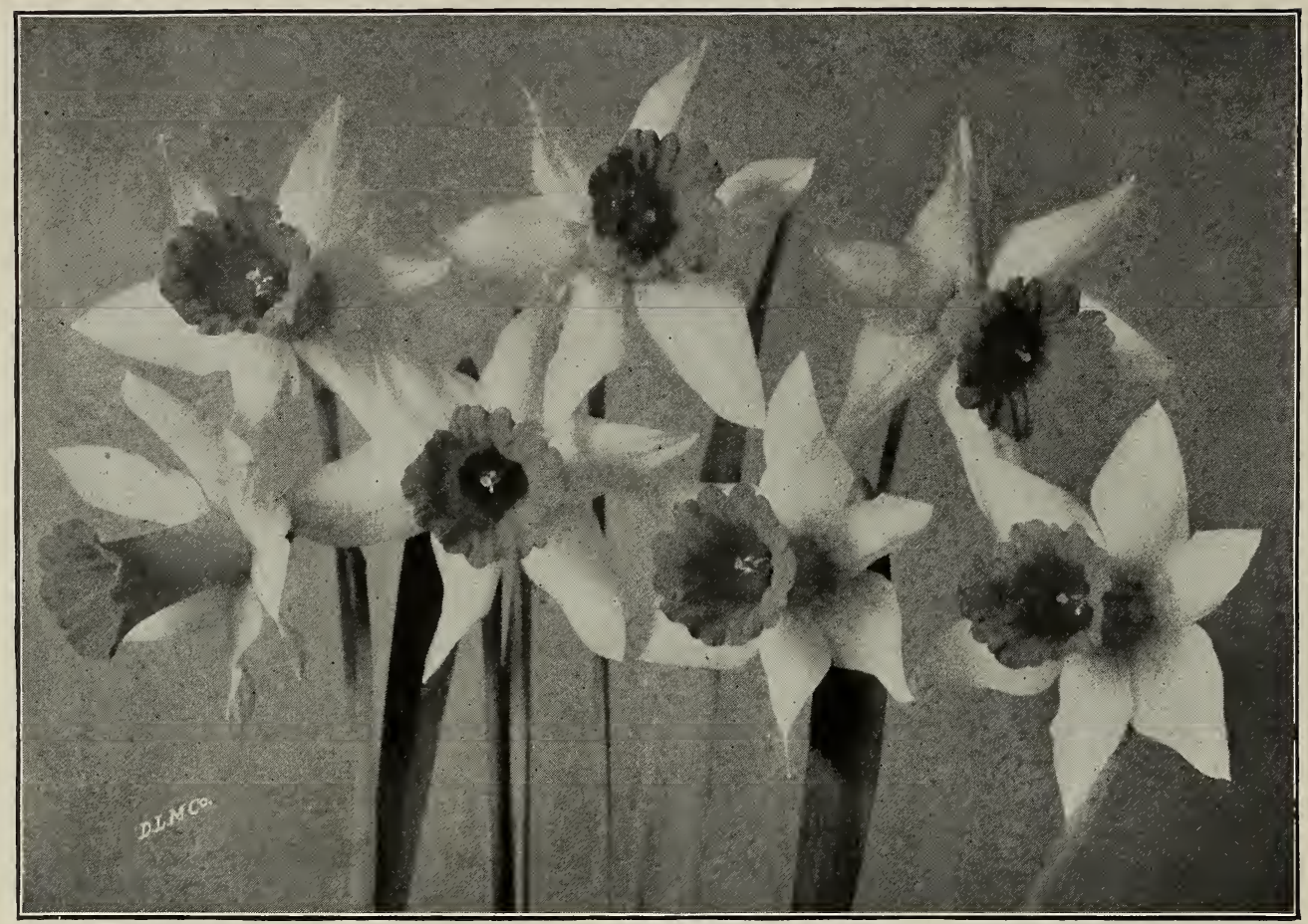

Empress Narcissus

\section{NARCISSUS, or DAFFODILS}

Every year the demand for these charming Spring-flowering bulbs is increasing. They are of easy culture, thriving in almost any soil, and are largely used for naturalizing. The following list contains all the most beautiful varieties, several of which are sweet-scented and excellent for cutting purposes.

Outdoor Culture. Plant four to five inches deep and four to six inches apart, according to size of bulbs. Being perfectlv hardv, they make an excellent effect among shrubbery in borders, etc.

Pot Culture. Use same composition as for Hyacinths. For effect plant six bulbs of one variety in bulb-pan or large pot. Keep in a cool dark place for a few weeks until well rooted.

\section{Single Narcissus, or Daffodils LARGE TRUMPET VARIETIES}

Albicans (Spanish Daffodils). Sul- Doz. 100

phur white trumpet............\$0.50 \$3.50

Ard Righ (Irish King). Large;

deep yellow trumpet; early........

EMPEROR. Immense flower, clear golden yellow trumpet, deep prim-

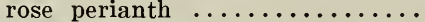

Mammoth Bulbs ............. EMPRESS (Bicolor). ' Rich yellow trumpet with pure, white perianth. An excellent forcer. Flowers

large and beautiful.............

Mammoth Bulbs .............

GOLDEN SPUR. (Mammoth Bulbs).

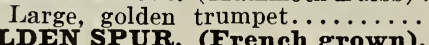

GOLDEN SPUR. (French grown).

Fine for forcing................

Grandee Maximus. Large yellow

Henry Irving. Very early ; dejep golden yellow trumpet, white perianth; very handsome............
Horsfieldi (King of Daffodils). A grand flower, large golden yellow trumpet, pure white perianth; a

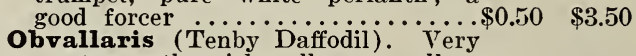
erect growth ; rich yellow ; excellent

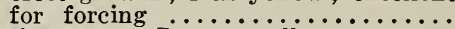

Princeps. Large yellow trumpet with sulphur perianth; excellent

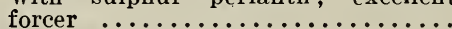

Scoticus. White petals, yellow trumpet; prettily fringed...... $\cdots$ (The Old-Fashioned Single Daffodil). Trumpet and perianth deep golden yellow ; extensively used for bed-

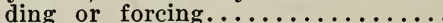

Trumpet Major (French). Same as the above but much earlier; largely used for forcing..........

VICTORIA (Bicolor). Large, clear yellow cup, beautiful, frilled, perianth creamy white.............

Finest Mixed. Large Trumpet varieties $\ldots \ldots \ldots \ldots \ldots \ldots \ldots \ldots \ldots . .30$ 
NARCISSUS-Continued

\section{MEDIUM TRUMPET VARIETIES}

Barrii Conspicuus. Large, boardspreading perianth primrose yellow; crown yellow conspicuously edged with orange scarlet; excellent for cutting............... $\$ 0.30$

Incomparabilis Cynosure. Large flower, primrose white perianth with orange scarlet crown; good for forcing ..................

Incomparabilis Figaro. Cup orange yellow, perianth yellow......

Incomparabilis Stella. White perianth, with orange yellow cup....

Incomparabilis, $S$ ir $W$ atkin (Giant Welsh Daffodil). Immense flower, primrose perianth often 5 inches across, cup rich golden yel-

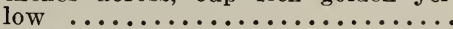

Leedsii. White; fragrant; excellent

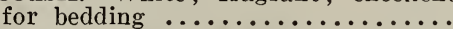

Leedsii, Queen of England. Large, pure white perianth, lemon cup....

Leedsii, Duchesse de Brabant. Pure white; small, canary yellow

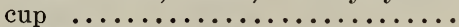

Leedsii, Mrs. Langtry. Broad white petals, white crown edged with yellow; distinct and beautiful.....

Finest Mixed. Medium Trumpet varieties $\quad \ldots \ldots \ldots \ldots \ldots \ldots \ldots$.

\section{NARCISSUS POETICUS VARIETIES}

Poeticus (The true Pheasant's Eye, Doz. 100 or Poet's Narcissus). Pure white, with red crown; very fragrant; excellent for cutting; the most popular variety for naturalizing....... $\$ 0.20$

Poeticus Ornatus. Larger than above; broad white perianth with

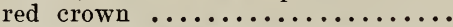

Poeticus, King Edward VII. The largest of this type. An exquisite flower $\quad . . \ldots \ldots \ldots \ldots \ldots \ldots$.

Poeticus Burbidgei. Petals pure white, cup yellow edged scarlet....

\section{HOOP PETTICOAT VARIETIES}

Bulbocodium (Yellow Hoop PettiDoz. 100 coat). Dwarf variety, with golden yellow flowers. Perfectly hardy... \$0.50

Bulbocodium Monophyllus. Same as above in white............. .75

\section{Narcissus, or Jonquils}

These flowers are highly prized for their rich perfume. They are excellent for pot culture, and being perfectly hardy, may be planted in open borders.

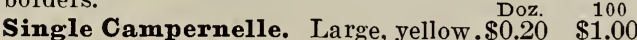

Odorus Rugulosus. Deep golden yellow, very fragrant; the best for

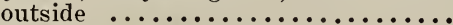

Silver Jonquil (or Tenuior Nar.

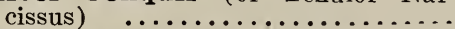

Single, Sweet-Scented. Rich yel-

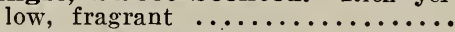

Double, Sweet-Scented. Golden yellow; extra fine flowers.........

.25

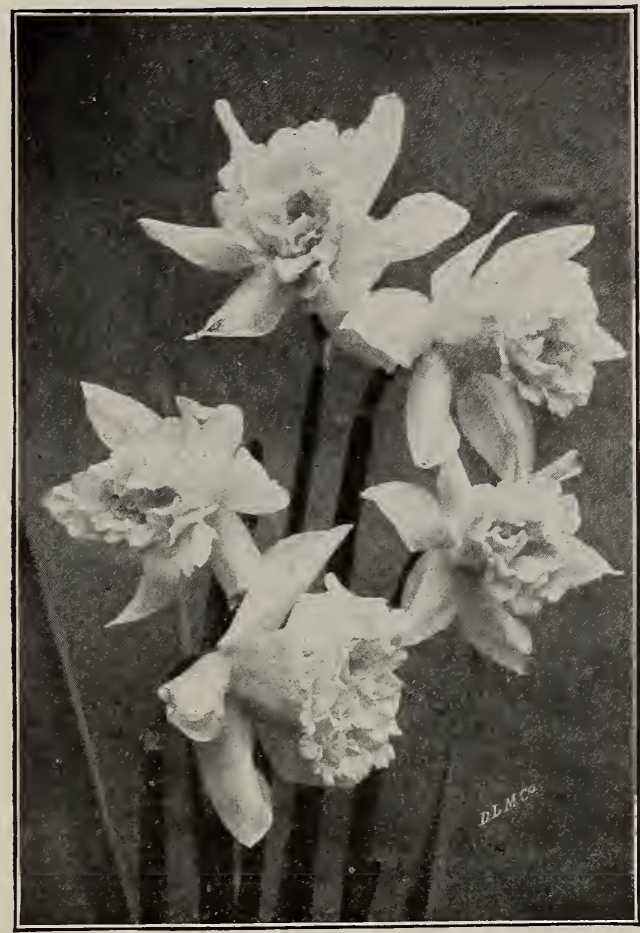

Narcissus Double Von Sion

\section{Double Narcissus}

Among the double varieties of Narcissus will be found some of the most popular sorts for forcing and outdoor planting. Their graceful habit and beautiful appearance make them admired by all lovers of flowers. They are perfectly hardy and no garden is complete without them.

Alba Plena Odorata (Double Doz. 100

Poet's Narcissus). Double; pure

white; very fragrant...........\$0.25 $\$ 1.50$

Incomparabilis Plenus (Büter and Eggs). Large; yellow with

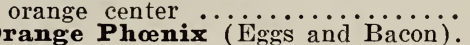

Orange Phonix (Eggs and Bacon). center; very effective............

sulphur, or silver Phœnix (Codlins and Cream). Pure white flowers $\ldots \ldots \ldots \ldots \ldots \ldots \ldots \ldots \ldots \ldots . .40 \quad 2.50$

\section{Von Sion}

(The Old-Fashioned Double Daffodil)

Flowers rich golden yellow; very decorative; excellent for cutting; extensively used for forcing purposes.

Single-Nosed Mammoth Bulbs.

$1000 \$ 20.00 \$ 0.40 \quad \$ 2.75$

Double-Nosed, Extra Selected

"Mother Bulbs" ....1000 $\$ 30.00 \quad .50 \quad 3.50$

Double Mixed, all colors 1000 $\$ 17.50 \quad 30 \quad 2.00$

$$
1000 \$ 17.50 \quad .30 \quad 2.00
$$

\section{Chinese Sacred Lily}

"Oriental Narcissus, or Fairy Flower." Flowers white with yellow cups, produced in bunches of five to six on each stem. They are generally grown in a dish or bowl half filled with pebbles and water, although they do well when grown in pots. Each 10c., doz. $\$ 1.00$. 


\section{POLYANTHUS NARCISSUS}

This variety of Narcissus is very early and invaluable for Christmas forcing. Flowers borne in clusters and very fragrant. Protect outdoors over Winter by light covering of litter.

PAPER WHITE GRANDIFTORA. This is

the largest and most popular of all the varie-

ties, and is extensively used for forcing for

cut flowers. Blooms much larger and earlier than in the old Paper White.

Bulbs $\ldots \ldots \ldots \ldots \ldots . .50 \quad 3.00$

Bazelman Major. White flowers

with yellow cup; very fragrant.... $1.50 \quad 8.00$

DOUBLE ROMAN. White, deep yellow cup; large truss..........

Gloriosa. White, deep orange cup..

Grand Monarque. White with primrose yellow cup; very fine...

Grand Primo. White yellow cup..

Grand Soleil d'Or. Yellow with deep orange cup..............

Mont Cenis. Pure white with citron cup; one of the finest for forcing...

Queen Victoria. White, with yellow cup; large, handsome flower..

States General. White, orange cup.

White Pearl. Extra fine large clusters satiny white flowers, citroncolored cups; profuse bloomer ....

Finest Mixed, all colors.........

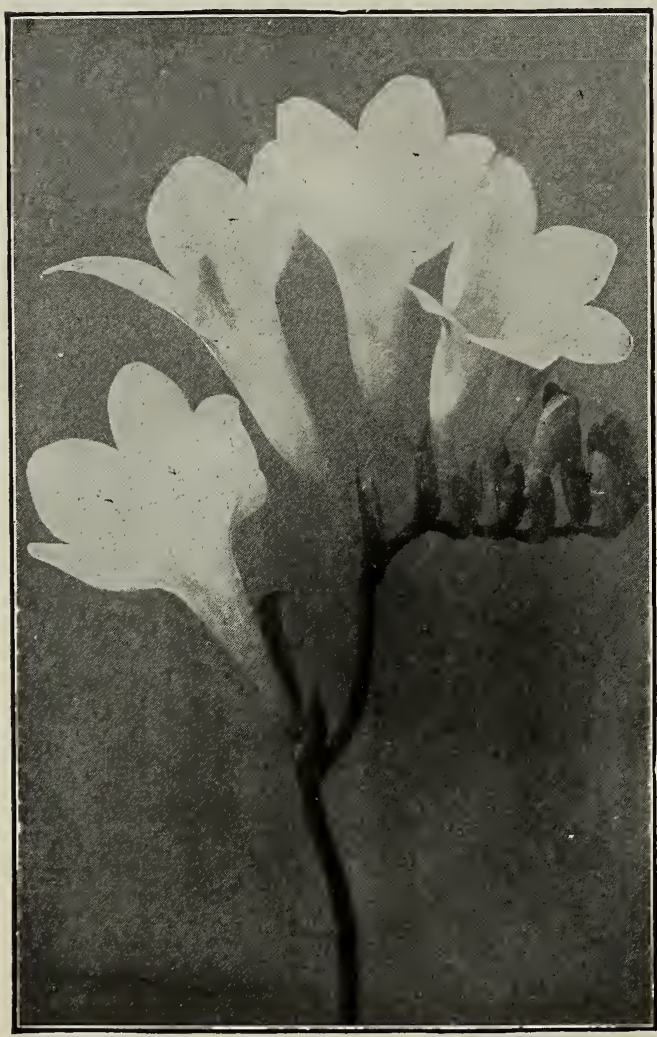

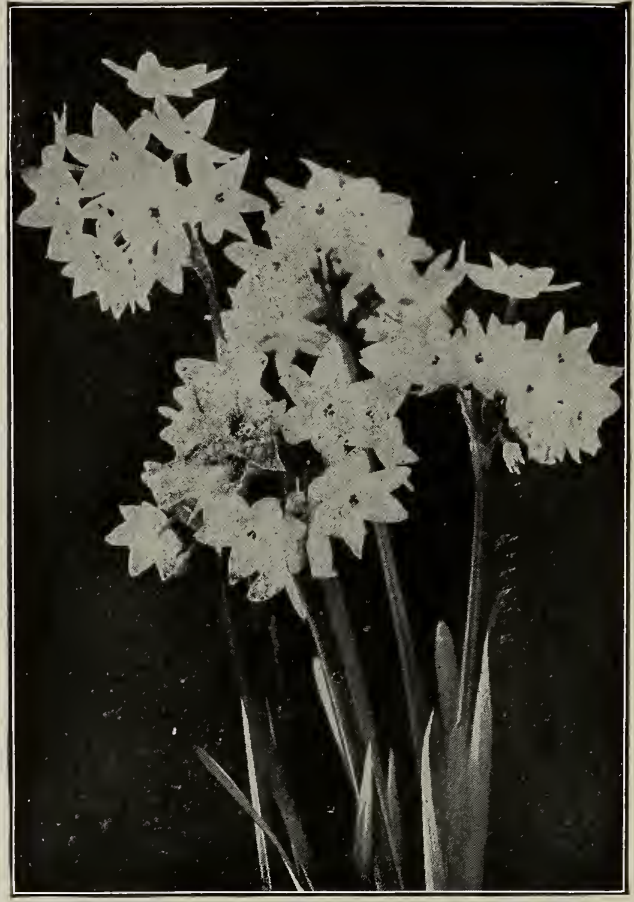

Narcissus Paper White Grandiflora

\section{FREESIAS}

The most popular of all Winter-flowering bulbs, for no other excels it in fragrance, grace of appearance and ease of culture. If planted early it can be had in bloom by Christmas. Ten or twelve bulbs should be used for a 6-inch pot or pan. Freesias do well when planted in benches in a cool house or frame.

\section{Fischer's Grand Freesia Purity}

This magnificent, glistening pure snow white Freesia, is undoubtedly the finest variety grown and is becoming more popular every year. The flowers are extra large and very fragrant. One bulb will throw from three to five flower spikes, each of which will have eight to eleven buds borne on extra long stiff stems, showing well above the foliage. Splendid for decorative purposes.

Mammoth Bulbs. Doz. 75c., $100 \$ 4.50$.

Large Selected Bulbs. Doz. 60c., $100 \$ 4.00$.

Direct from the grower in original bags.

\section{Freesia Refracta Alba}

California Grown Mammoth Bulbs. Doz. 40c., $100 \$ 2.50,1000 \$ 20.00$.

Large Selected Bulbs. Doz. 25c., $100 \$ 1.75$, $1000 \$ 15.00$.

French Grown Mammoth Bulbs. White, blotched yellow. Doz. 25c., $100 \$ 2.00,1000 \$ 20$.

Large Selected Bulbs. Doz. 20c., $100 \$ 1.75$, $1000 \$ 15.00$.

Leichtlini Major. Beautiful golden yellow flowers. Large size bulbs. Doz. 30c., $100 \$ 2.00$. 


\section{CALLA, or LILY OF THE NILE}

Callas are easily grown in pots or benches, requiring only rich soil and plenty of water. We take great care to secure only bulbs which are free from disease, thoroughly ripened and when forced will give satisfactory results.

White Calla (Richardia Ethio- Each Doz. pica)

Extra Large Dry Bulbs.... . . \$0.25 $\$ 2.75$

1st Size Dry Bulbs......... .15 1.50
Spotted Leaf Calla (Richardis alba maculata) ............. \$0.15 $\$ 1.50$

Dwarf Calla "Little Gem" (Richardia nana) ................. 101.00

Yellow Calla (Elliottiana). Flowers deep golden yellow.......... .50 5.00

Black Calla (Arum sanctum) ..... .20 2.00

\section{CROCUS}

Crocus make a gorgeous display when planted in masses or in a border. They can also be planted on the lawn among the grass, where they look very pretty in the early Spring. They are perfectly hardy and can be left in the ground for several years.

\section{Hybrid Named Crocus}

\section{Mammoth Flowering Sorts}

The bulbs of Hybrid named Crocus are from three to four times larger than the ordinary common sorts and will produce much finer flowers.

\begin{tabular}{|c|c|c|c|}
\hline 50 & & $\begin{array}{l}100 \\
\$ 1.00\end{array}$ & $\begin{array}{l}1000 \\
\$ 8.00\end{array}$ \\
\hline $\begin{array}{c}\text { Baron von Brunow. Dark } \\
\text { blue } \ldots \ldots \ldots \ldots \ldots \ldots \ldots \ldots \ldots\end{array}$ & .15 & 1.00 & 8.00 \\
\hline avid Rizzio. Deep purple.. & .1 & & 00 \\
\hline $\begin{array}{l}\text { Mammoth Yellow. Large } \\
\text { golden yellow flowers....... }\end{array}$ & .1 & 1.00 & 8.00 \\
\hline $\begin{array}{l}\text { Mont Blanc. Pure white... } \\
\text { Non Plus Ultra. Blue, white }\end{array}$ & .1 & 0 & 00 \\
\hline 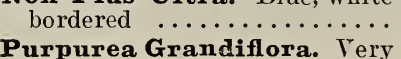 & 1 & $1 .($ & 8.00 \\
\hline & .1 & 1.00 & 8.00 \\
\hline Queen Victoria. I'ure white & .1 & 1.00 & 8.00 \\
\hline $\begin{array}{l}\text { La Majesteuse. White, vio- } \\
\text { let-striped } \ldots \ldots \ldots \ldots \ldots \ldots \ldots\end{array}$ & .1 & 1.00 & 8.0 \\
\hline $\begin{array}{c}\text { Sir Walter Scott. White, } \\
\text { blue-striped } \\
\ldots \ldots \ldots \ldots \ldots \ldots\end{array}$ & .1 & 1.00 & 8.00 \\
\hline $\begin{array}{l}\text { Cloth of Gold. Yellow and } \\
\text { brown } \ldots \ldots \ldots \ldots \ldots \ldots \ldots\end{array}$ & .1 & 1.00 & 8.0 \\
\hline Cloth of Silver. White and & & 1.00 & 8.0 \\
\hline
\end{tabular}

CROCUS, SEPARATE COLORS

$\begin{array}{lll}\text { Doz. } & 100 & 1000\end{array}$

Purple. Mixed .....\$0.10 $\$ 0.50 \quad \$ 4.50$

Striped and Variegated $.10 \quad .50 \quad 4.50$

White. Mixed ........ $.10 \quad .50 \quad 4.50$

Large Yellow $\ldots \ldots \ldots . .15 \quad .75 \quad 5.00$

Fine Mixed. All colors. $\quad .10 \quad .50 \quad 4.00$

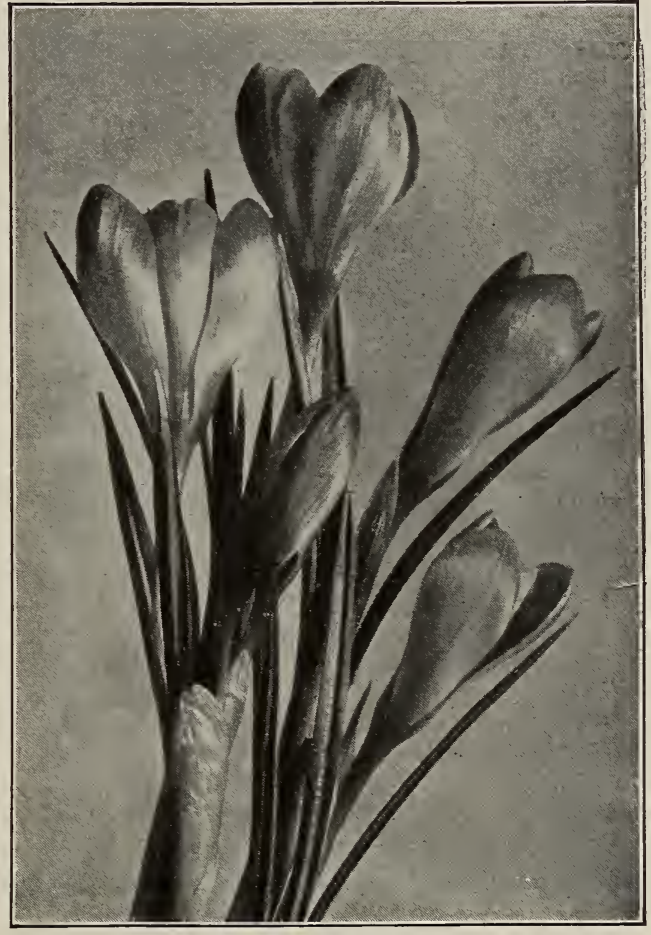

Hybrid Named Crocus

\section{Autumn-Flowering Crocus}

(Colchicum Autumnale)

If planted in the Fall these Crocus will flower in October, the leaves appearing early in the following Spring. Very effective for borders or among shrubbery. Each Doz. 100 Monster Bulbs ..........\$0.08 $\$ 0.75 \$ \$ 5.00$

\section{MISCELLANEOUS HYACINTHS}

These very pretty hardy bulbous plants are specially adapted for mixed borders and naturalizing. They succeed in almost any soil, and require little care.

Muscari botryoides. $\quad$ Doz. 100

Grape Hyacinth. White......\$0.30 $\$ 1.50$

Blue $\ldots \ldots \ldots \quad .20 \quad 1.00$

moschatus. Pale yellow ....... 1.2510 .00

Plumosus (Feathered Hyacinth).

Blue ........................ 1.50
Cape Hyacinths (Hyacinthus Candicans). A beautiful snow white, Summer-flowering hardy plant, with flower stems 3 to 4 feet high, bearing from 20 to 30 large, drooping flowers.

Each 5c., doz. 50c., $100 \$ 3.00$. 


\section{Lilium Harrisii}

\section{(The True Bermuda Easter Lily)}

This grand Winter-flowering plant is at present the general favorite. It can be had in bloom at any desired period, such as Christmas and Easter. At these times it is very largely used for table and church decorations, also other special occasions. The flowers are pure waxy white of great substance, tubular in shape and very fragrant. If cut when partially opened and put in water they will remain in perfect condition for over two weeks. The bulbs we offer are all carefully selected, very solid and should give satisfactory results.

First Size Bulbs. 5 to $7^{\text {Each }}$ Doz. 100 inches in circumference. Bulbs should produce from

4 to 5 flowers............\$0.10 \$1.00 \$7.00

Extra Size Bulbs. 7 to 9

inches in circumference.

Bulbs should produce from

10 to 12 flowers..........

Mammoth Size Bulbs. 9 to 11 inches in circumference. Generally grown for exhibition. Each bulb should produce from 12 to 18 flowers $\ldots \ldots \ldots \ldots \ldots \ldots \ldots \ldots, \quad .50 \quad 4.00 \quad 30.00$

\section{Lilium Candidum}

(Annunciation, or St. Joseph Lily)

The renowned garden favorite; grows 3 to 4 feet high, bearing immense snow-white, fragrant flowers. Being perfectly hardy it should be planted in the open ground in August to insure strong crowns before severe weather sets in, when it will bloom profusely the following June. The bulbs we offer are grown in the north of France, and are far superior to home-grown stock.

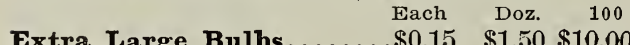
Monster Bulbs ............ $20 \quad 2.00 \quad 15.00$

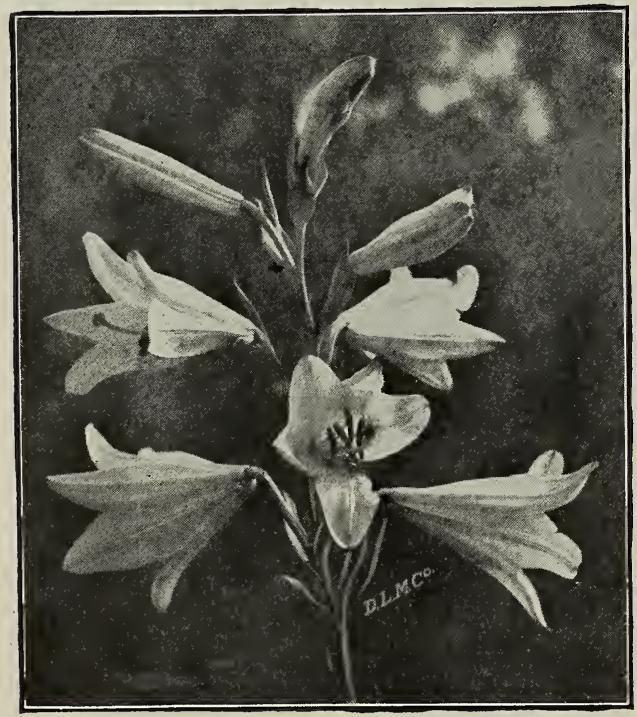

Lilium Candidum

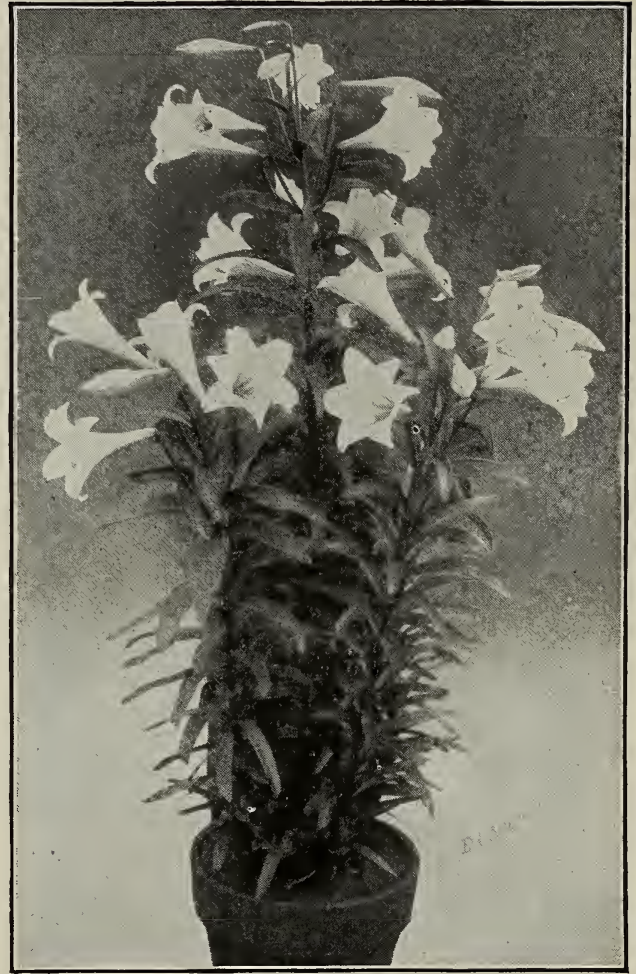

Lilium Harrisii

\section{Lilium Longiflorum}

(The White Trumpet Lily)

Japan Grown. Ready About Sept. 20

This well-known Lily is becoming more popular every year for forcing. It grows 2 to 3 feet high and blooms abundantly, flowers trumpet shaped, pure white, and very sweet-scented; perfectly hardy; also valuable for outdoor planting.

First Size Bulbs. 6 to Each Doz. 100

inches $\ldots \ldots \ldots \ldots \ldots \ldots \ldots \ldots . \$ 0.10 \quad \$ 0.75 \$ 5.00$ Extra Size. 7 to 9 inches... $.15 \quad 1.25 \quad 8.00$ Mammoth Size. 9 to 10 ins. $.25 \quad 2.50 \quad 15.00$

\section{Lilium Longiflorum Multiflorum}

Japan Grown. Ready About Sept. 20

About ten days earlier than the ordinary Lilium Longiflorum, with large pure white flowers.

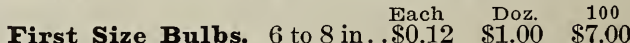

Extra Size. 7 to 9 in....... $\mathbf{. 1 5} \quad \mathbf{1 . 2 5} 10.00$

$\begin{array}{lllll}\text { Mammoth Size. } 9 \text { to } 10 \mathrm{in} \text {. } & .25 & 2.50 & 17.00\end{array}$

\section{Lilium Longiflorum Giganteum}

Flowers about a week later than L. Longiflorum blooms larger and more perfect in form; stems marked black. $\quad$ Each Doz. 100

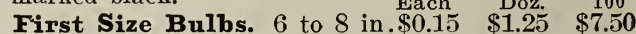
$\begin{array}{lllll}\text { Extra Size. } 7 \text { to } 9 \text { in . . . . } & 20 & 2.00 & 12.00\end{array}$ Mammoth Size. 9 to 10 in.. 


\section{HARDY LILIES For Outdoor Planting}

Owing to the large production in Japan, which has reduced the prices to a much lower point than prevailed in former years, the demand for "Hardy Lilies" is rapidly increasing. Their stately habit. beautr of form and variety of colors, combined with the various species. make them worthy of a place in every collection. They commence flowering in May and maintain a continuous succession of bloom until Autumn. Excellent for backgrounds and shrubbery borders.

Auratum (The Golden Lily of Japan). White, spotted with crimson, having a bright yellow band through the center of each petal; fragrant.

Extra Size Bulbs. 9 to

11 inches $\ldots \ldots \ldots \ldots \ldots . . . . . .250 .25 \quad \$ 2.50 \$ 15.00$

11 to 13 inches.........

Atrosanguineum (Fulgens). Rich deep crimson with dark

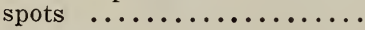

Batemani. Apricot color, tinted flowers ...........

Brownii. Large trumpetshaped flowers, interior pure white, exterior purplish

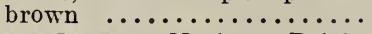

Canadense. Native. Bright yellow flowers with black

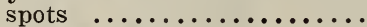

CANDIDUM. See page 12.

Chalcedonicum (S c a rle t Turk's Cap). Brilliant scarlet recurved flowers........

Formosum. An early flowering variety of the Harrisii type. Free from disease ; extra large bulbs............

Krameri. Blush pink; fragrant with beautiful trumpet-shaped flowers ........

$\begin{array}{lll}.40 & 3.500 & 25.00\end{array}$

$.30 \quad 3.00$

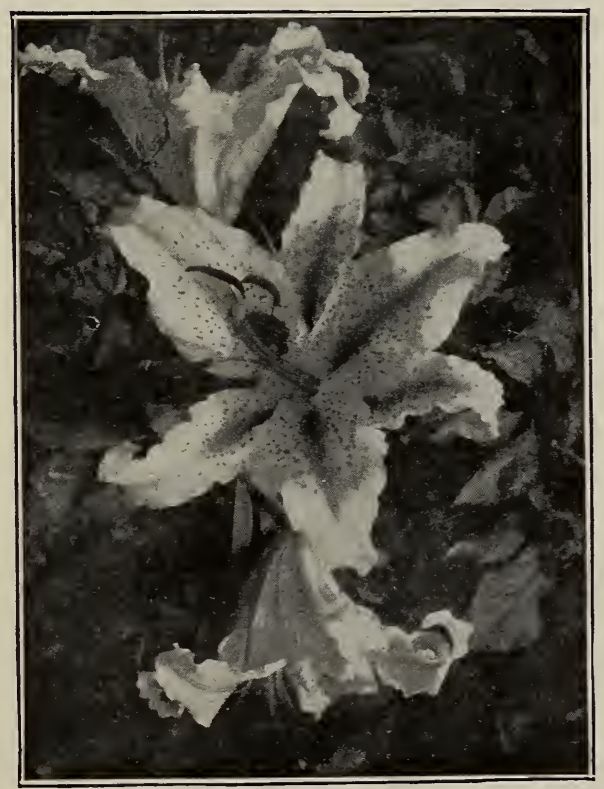

L. Speciosum Rubrum

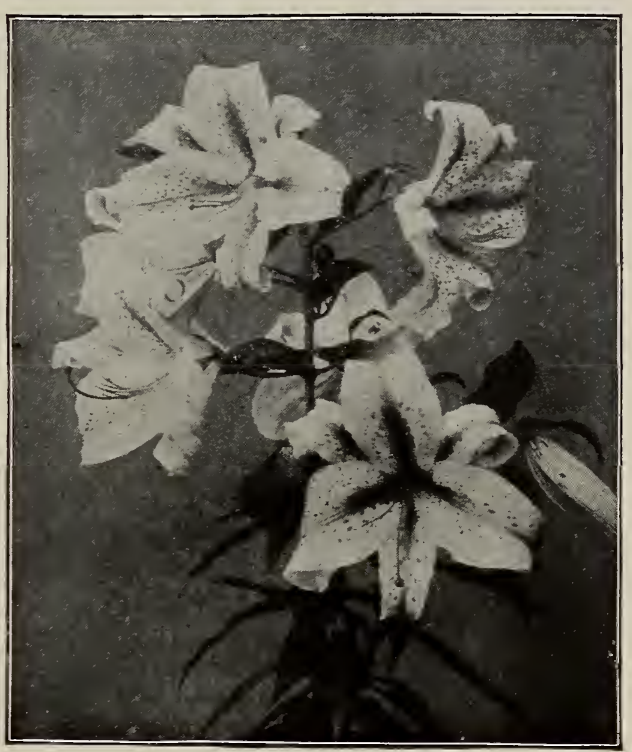

Lilium Auratum

Each Doz. 100

Brightphicum. Native.

ple spots $\ldots \ldots \ldots \ldots \ldots \ldots \ldots . \$ 0.15 \$ 1.50$

Speciosum Album. Pure white, fragrant, 9-11 ins.. $.30 \quad 3.00 \$ 20.00$

Roseum. White, spotted deep red. 9 to 11 inches.

Rubrum. Rose, spotted crimson ..............

Magnificum. 9 to 11 inches. Rich red, heavily spotted; very fine..........

Melpomene. Rich crimson heavily spotted. 9-11 ins..

Superbum. Deep orange red

Tenuifolium (Coral Lily of Siberia). Brilliant scarlet flowers, very early.........

Tigrinum (Tiger Lily). Orange salmon; 3 feet high. 9

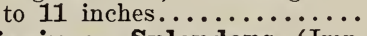

Tigrinum Splendens (Imp. Tiger Lily). Rich scarlet, with black spots; large

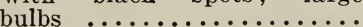

Tigrinum Flore Plena (New double Tiger Lily)...

Wallacei. Clear buff, spotted with black............

Washingtonianum. Flowers, pure white, tinted pur-

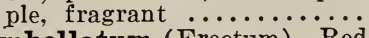

Umbellatum (Erectum). Red flaked, yellow spotted......

Umbellatum (Grandiflorum) Orange spotted, crimson.... $\begin{array}{lll}.20 & 2.00 \quad 15.00\end{array}$

$\begin{array}{lll}.30 & 3.00 \quad 20.00\end{array}$

$\begin{array}{lll}.20 & 2.00 & 15.00\end{array}$

$\begin{array}{lll}.15 & 1.50 & 10.00\end{array}$

$.15 \quad 1.50$

$.10 \quad 1.00 \quad 7.50$

$\begin{array}{lll}.15 & 1.50 & 12.00\end{array}$

$\begin{array}{lll}.15 & 1.50 & 10.00\end{array}$

$.15 \quad 1.50$

$.30 \quad 3.00$

$.15 \quad 1.50$

$.15 \quad 1.50$ 


\section{MISCELLANEOUS BULBS AND ROOTS}

\section{AMARYLLIS \\ Ready in October}

Very ornamental greenhouse plants, with large, fragrant, beautifully colored flowers. The growing season is from early Spring until about September, when the plants should be kept cool and allowed to rest until February. They require plenty of sunshine, but in the flowering season a light shading is necessary.

Aulica (Lily of the Palace). Crim Each Doz. son, shaded with green ..........\$1.00 $\$ 10.00$

Belladonna Major. Flowers trumpet-shaped, of a beautiful silvery white, flushed and tipped with rose borne on stems 2 to $2 \frac{1}{2}$ feet in height. Large bulbs............

Formosissima (Jacobean Lily). Beautiful flowers of rich dark scarlet color; forces well and can be

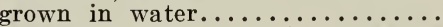

Johnsonii. A popular sort and one of the best for general culture; flowers, crimson, striped white.....

\section{ZEPHYRANTHES}

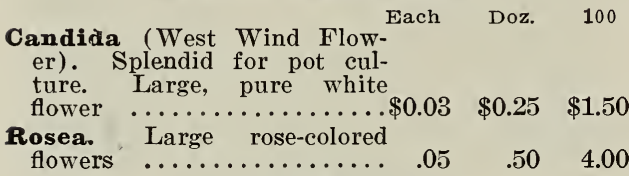

\section{ACHIMENES}

Ready in November

Splendid and profuse Summer-blooming plants for the conservatory or window garden.

Mixed Varieties. Ea. 10c., doz. $\$ 1.00,100 \$ 8.00$.

\section{ACONITE, WINTER}

\section{Eranthis Hyemalis}

One of the earliest Spring flowers, color golden yellow, forming a charming picture against the dark green foliage. Doz. 30c., $100 \$ 2.00$.

\section{ALSTROMERIA. Peruvian Lilies}

Ready in November

Beautiful flowers borne in clusters, splendid for pots or frames.

Mixed Colors. Each 10c., doz. $\$ 1.00$.

\section{ALLIUM NEAPOLITANUM}

Flowers pure white, with green stamens, borne in large umbels, very easily forced, and excellent for cut flowers. Doz. 25c., $100 \$ 1.25$.

\section{ANEMONE, or WINDFLOWER}

Very ornamental hardy perennials, producing beautifully colored flowers in Spring and Summer. They do best in a sheltered position.

Doz. 100 rich dazzling scarlet flowers make it very attractive $\ldots \ldots \ldots \ldots \ldots \ldots . \$ 0.50 \quad \$ 3.00$

st. Brigid. Distinct bright colors with extra large flowers........ .50 3.50

Single. Finest mixed........... .25 1.50

Double. Finest mixed............ . .30 2.00

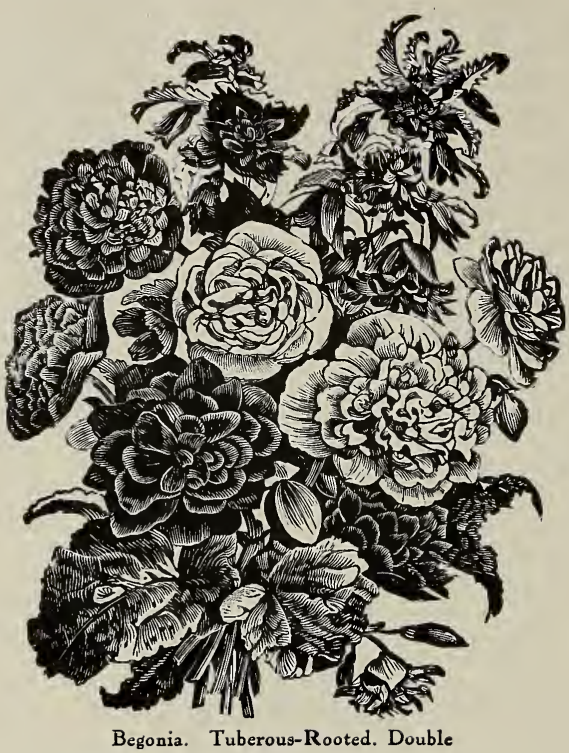

BEGONIA, Tuberous-Rooted Ready in November

Splendid pot plants, also valuable for bedding, flowering in the greatest profusion throughout the Summer. For bedding they should be started in a hotbed in March or April.

Single, Crimson, Scarlet, Rose Each Doz. 100

White, Yellow, Pink......\$0.10 $\$ 0.75 \$ \$ 5.00$

Mixed .................. $10 \quad .75 \quad 5.00$

Double, White, Yellow, Scar-

let, Pink, Rose............... $15 \quad 1.25 \quad 7.50$

Mixed ............... .15 $1.25 \quad 7.50$

\section{BABIANAS}

These beautiful little flowers can be grown in pots for Winter flowering, or plant in cold frames for Spring blooming.

Mixed Colors. Doz. 40c., $100 \$ 3.00$.

\section{BRODIAEAS}

Half hardy California bulbs; succeed well in greenhouse or cold frame.

Mixed Colors. Doz. 30c., $100 \$ 2.00$.

\section{CHIONODOXA. Glory of the snow}

The most beautiful of the dwarf blue Spring flowers. Extensively used for wild gardens, woodland planting, shrubbery, etc.; perfectly hardy.

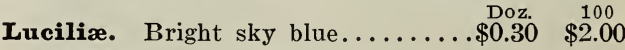

Gigantea. Larger flowers than C.

Luciliæ. Blue with white center... $\quad .30 \quad 2.00$

Sardensis. Rich deep blue....... . .30 2.00

\section{CROWN IMPERIALS}

Well-known stately growing plants for outdoor culture, with dark green foliage and flowers of various shades of yellow and crimson.

Mixed Colors. Each 15c., doz. $\$ 1.50$. 


\section{CYCLAMEN}

\section{Ready in November}

It is difficult to find a more useful plant than Cyclamen for greenhouse and window decorations. The various species produce flowers varying from deep red to pure white. C. giganteum is an im. proved strain of the old C. persicum. having mach larger and more brilliantly colored flowers.

Persicum Giganteum. Large bulbs. Mized colors. Each 20c., doz. $\$ 2.00$.

\section{DIELYTRA SPECTABILIS}

\section{Bleeding Heart}

The well-known Spring-flowering plant, producing long, drooping racemes of delicate white and pink heart-shaped flowers.

Large Clumps. Each 25̌c., doz. \$2.50.

\section{ERYTHRONIUM}

\section{Dog's Tooth Violets}

Very ornamental hardy plants with variegated foliage; flowers large, varying in color from white to deep purple.

Mixed Colors. Doz. 50c., $100 \$ 3.00$.

\section{FRITILLARIA MELEAGRIS}

\section{Guinea-Hen Flower}

Graceful, hardy Spring-flowering plants of great beauty; grows well in shaded places.

Finest Mixed. Doz. 50c., $100 \$ 2.50$.

\section{GLADIOLUS. Early Flowering}

\section{Ready in November}

An extremely early class of exquisite beauty, largely used for forcing and planting in open ground. The flowers are borne on long, stiff stems. For Spring-flowering store bulbs in dry sand until May and plant out; when they will flower in June.

Colvillei Alba (The Bride). Pure Doz, $\quad 100$

white ................... \$0.30 \$1.50

Colvillei (Blushing Bride). (True).

Ivory white flaked carmine...... .25 2.00

Colvillei. Purple and straw....... .30 1.50

Colvillei Rubra. Purplish red.... $.30 \quad 2.00$

Peach Blossom. A beautiful shade of pink, excellent for cutting..... $.50 \quad 3.00$

\section{GLOXINIAS}

Bulbs Ready in November

Charming greenhouse plants, of dwarf habit. The flowers-often three to four inches acrossare produced in great profusion, and are of the most exquisite and gorgeous colors, many of which are magnificently spotted, mottled and blended. They bloom continuously for months, and by starting at intervals, a succession may be had nearly the whole year round.

Each Doz 100

Crassifolia Erecta. Red....\$0.15 $\$ 1.50 \$ 10.00$

\begin{tabular}{|c|c|c|c|c|}
\hline 6 & " & White. & .15 & 1.50 \\
\hline “6 & " & Blue... & .15 & 1.50 \\
\hline 66 & “ & Spotted. & .15 & 1.50 \\
\hline 86 & " & Mixed.. & .15 & 1.50 \\
\hline
\end{tabular}

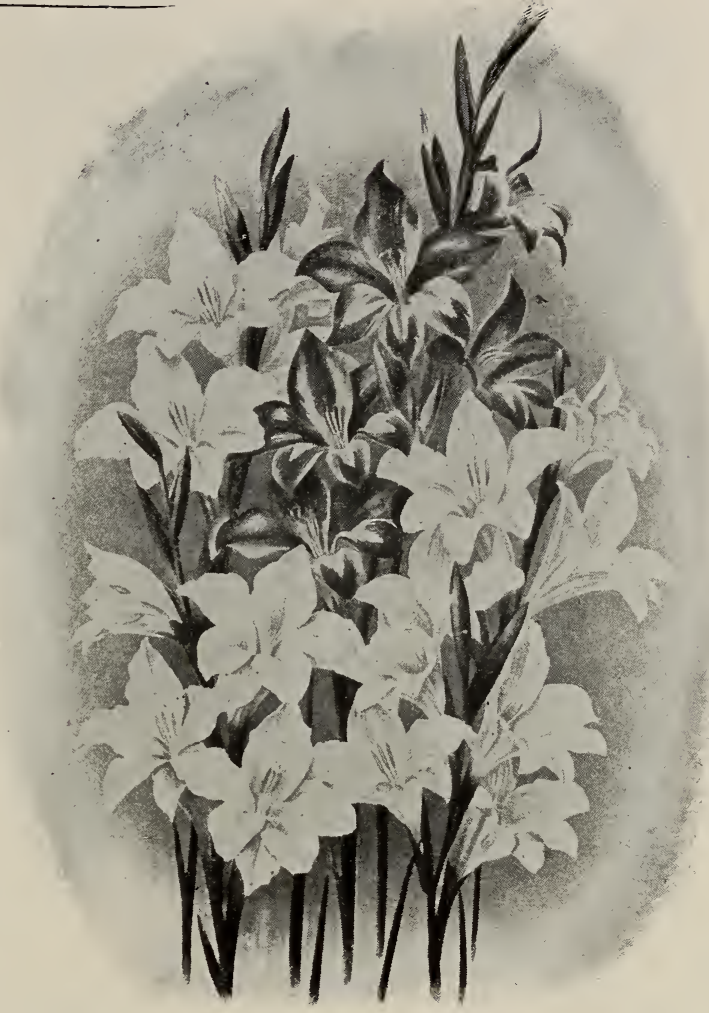

Gladiolus Colvillei, Rubra and Alba.

\section{HELLEBORUS NIGER}

\section{Christmas Rose}

One of the most valuable hardy plants, blooming at a season when flowers are scarce. They will succeed in almost any soil and, if plenty of dressing is used, blooms may be had two or three inches across. Color pure white. Each 35c., doz. $\$ 3.50$.

\section{HEMEROCALLIS. Day Lily}

Flava (Yellow Day Lily). Bright Each Doz.

yellow, fragrant flowers........\$0.20 $\$ 2.00$

Kwanso fl. pl. Flowers of a rich,

orange copper color............ .25 2.50

Middendorfiana. Deep golden yel-

low flowers .................... .25 2.50

\section{ISMENE CALATHINA}

\section{Sea Daffodil}

Pure white, large lily-like blossoms which appear in threes and fours on a stalk. Specially adapted for pot culture. Each 15c., doz. $\$ 1.50$, $100 \$ 10.00$.

\section{IXIAS}

Very ornamental half-hardy bulbs, suitable for indoor or outside culture in well protected borders. Mixed Varieties. Doz. 25c., $100 \$ 1.25$. 


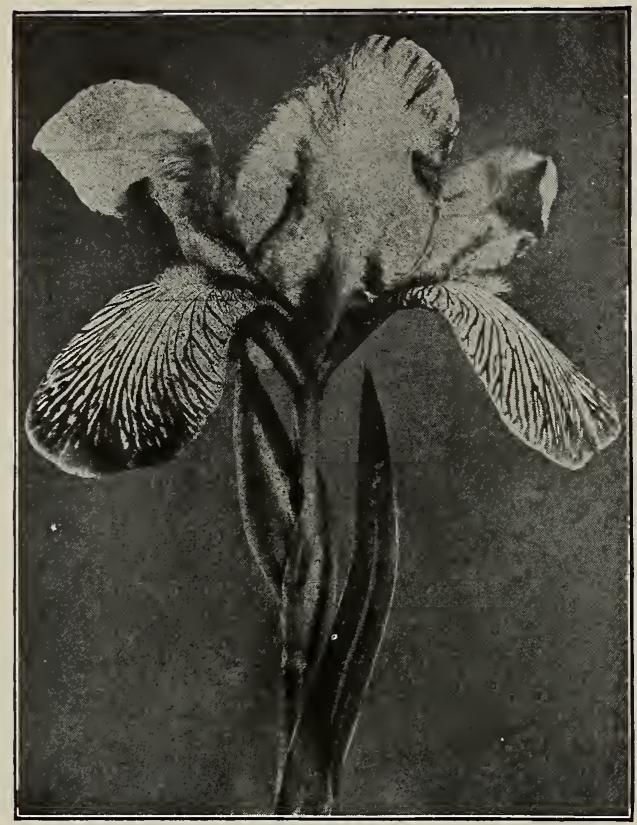

Iris Hispanica

\section{IRIS (FLEUR-DE-LIS)}

\section{The Orchid of the Garden}

These magnificent flowering bulbs are highly prized for outdoor culture. They are easily cultivated, perfectly hardy and when well established, will stand for years.

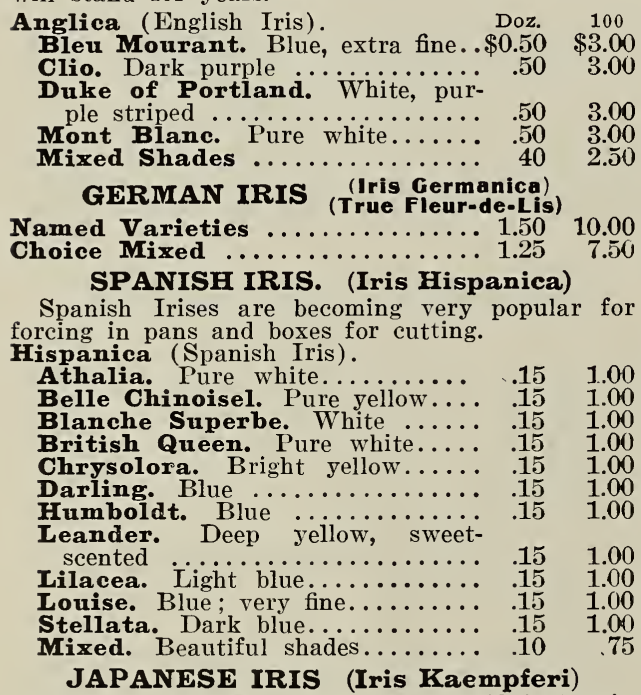

These flowers often measure 10 to 12 inches in diameter, and are of the most varied and beautiful colors. They require rich, moist soil. Our collection is a direct importation from Japan and is remarkably fine. Named varieties; strong clumps. Each 30c., doz. $\$ 3.00$.

Choice Mixed Sorts. Each 25c., doz. \$2.50, $100 \$ 15.00$

\section{NERINE SARNIENSIS}

\section{Guernsey Lily}

This flower is one of the earliest of the Amaryllis family. Erect stems producing crowns of beautiful scarlet flowers. Each 30c., doz. $\$ 3.00$.

\section{MONTBRETIAS}

\section{Ready in November}

These elegant hardy border plants with gracefully branched gladiolus-like flowers, are much prized for cutting during Summer. Colors ranging from clear yellow to rich scarlet. Plant bulbs five inches deep. A slight protection during Winter is necessary.

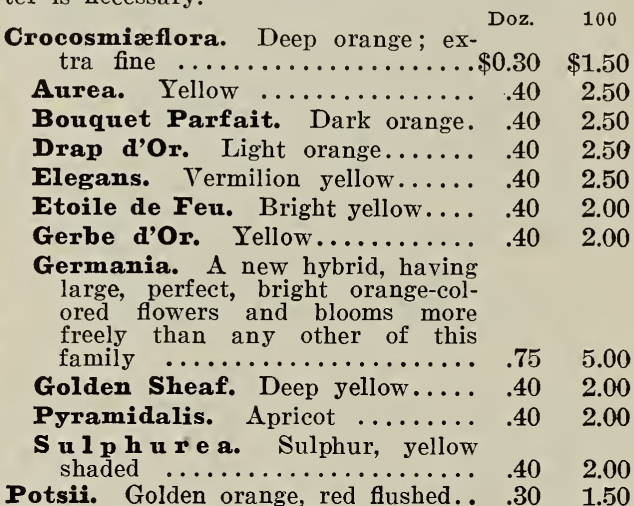

\section{OXALIS}

Ready in September

A very popular plant for hanging baskets or pots, producing vast quantities of brilliant flowers during the Autumn and Winter months.

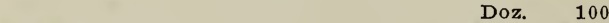

Alba. White ............... $\$ 0.30 \quad \$ 2.00$

Buttercup. Flowers bright yellow

and produced in great abundance.. $\quad .50 \quad 3.00$

Bowiei. Crimson ................. $\quad .30 \quad 2.00$

Hirta Rosea. Rose............. . .30 2.00

Lutea. Double, Yellow.......... $.50 \quad 3.00$

Versicolor. Crimson and white... $.25 \quad 1.50$

Mixed $\ldots \ldots \ldots \ldots \ldots \ldots \ldots \ldots \ldots, .25 \quad 1.50$

\section{ORNITHOGALUM ARABICUM}

\section{Star of Bethlehem}

Flowers, pure white, with black center, borne in clusters on stalks from 15 to 18 inches high; perfectly hardy; excellent for the open border. Also largely grown for greenhouse and window decoration. Doz. 50c., $100 \$ 3.00$.

\section{PANCRATIUM MARITIMUM}

A lily-like plant; flowers fragrant, white, very showy, borne in large clusters. Each 20c., doz. \$2. 


\section{PEONIES}

Peonies are too well known to require description. Their popularity is due to their easy culture, handsome appearance, brilliant and striking effect of their immense, finely formed, richly colored flowers.

\section{DOUBLE HERBACEOUS CHINESE} Ready in October

Our collection of these plants in named varieties embraces the choicest and most beautiful shades.

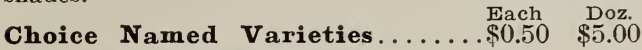

Separate Colors, in Red, White,

Pink and Rose..................25 2.50

\section{PAONIA OFFICINALIS}

The real old-fashioned "Pæony," comes into bloom about two weeks earlier than the above sorts, with large, double fragrant flowers.

Albar.... Each Doz. Alba. Double, blush white.......\$0.30 $\$ 3.00$

Rosea. Double, rose pink......... $\quad .30 \quad 3.00$

Rubra. Double, brilliant deep crim-

son $\ldots \ldots \ldots \ldots \ldots \ldots \ldots \ldots \ldots \ldots . .30 \quad 3.00$

\section{RANUNCULUS}

Very handsome flowers of fine form, colors brilliant and attractive. Plant late in Autumn.

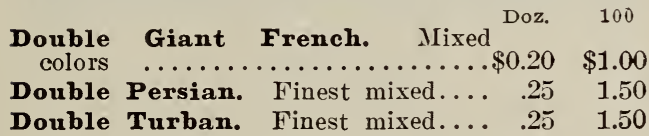

\section{SPARAXIS}

Graceful hardy bulbous plants, specially adapted for pot culture in the conservatory or window garden. Plant eight to twelve bulbs in a 6 inch pot or bulb pan.

Finest Mixed Varieties. Doz. 25c., $100 \$ 1.00$.

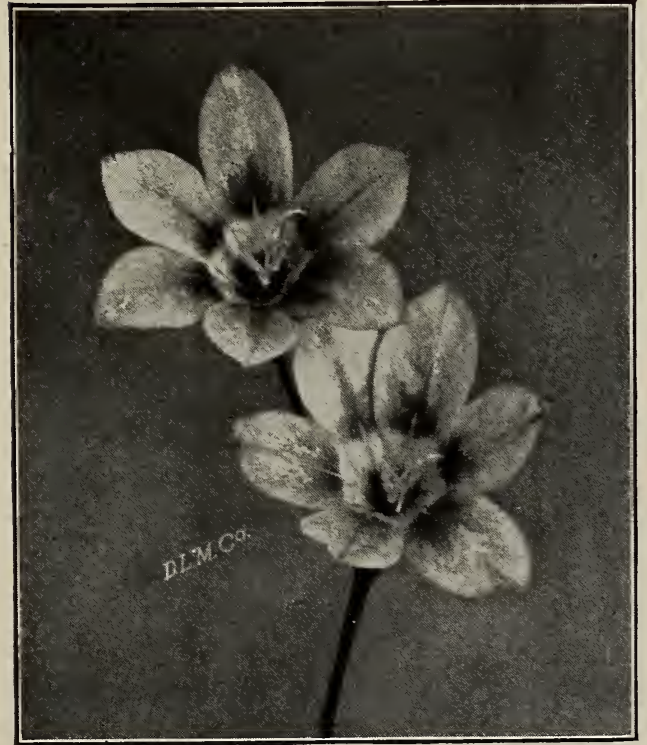

Sparaxis

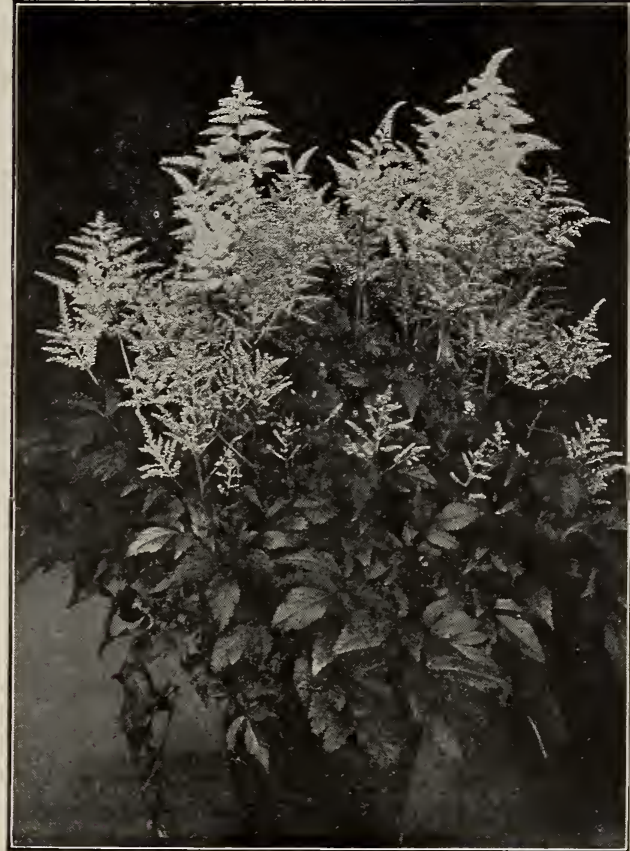

Spiraea Japonica

\section{SPIRAEA}

Ready in November

Tall, graceful, branching. herbaceous perennials, with feathery panicles, thricing in rich soil and damp positions. Those we list are extensively used for forcing or decorative purposes. They should be potted when received and buried outside till they begin to form roots, when they may be taken in and forced as required. Perfectly hardy.

Japonica. Large white feathery flowers; largely grown for forcing in pots, and splendid for cutting. Each 15c., doz. $\$ 1.50,100 \$ 8.50$.

Nana Compacta Multiflora. Dwarf and compact with bright green foliage, and handsome, pure white feathery flowers; excellent for forcing. Each 15c., doz. $\$ 1.50$, $100 \$ 10.00$.

Astilboides Floribunda. Very large, pure white plumes; an early and profuse bloomer. Each 15c., doz. $\$ 1.50,100 \$ 10.00$.

Gladstone. A large flowering, beautiful pure white variety, borne on erect stalks, showing well abore the foliage. A splendid forcer. Each 25 c., doz. $\$ 2.50,100 \$ 15.00$.

Superbe (Abundant Flowering). A grand new rariety which makes a perfect shaped plant with from 20 to 30 pure white spikes borne on strong stalks. Each 20c., doz. $\$ 2.00,100 \$ 12.00$.

Queen Alexandra. A magnificent shell pink variety, in habit similar to the well-known Gladstone. Splendid for forcing. Each 25c., doz. $\$ 2.50,100 \$ 18.00$.

Peach Blossom (New). A beautiful pink; fine for forcing. Each 30c., doz. $\$ 3.00,100, \$ 20.00$. 


\section{SCILLA}

Scillas, or Bluebells, are of dwarf habit, with drooping bell-shaped flowers. Bloom very early; thrive in any situation. Excellent for borders or planting with Snowdrops; perfectly hardy.

Sibirica. Flowers bright

blue. Large bulbs........\$0.30 $\$ 1.75 \$ 12.00$

Sibirica Alba. Pure white. $.50 \quad 4.00$

Campanulata Alba. Pure

white; 12 in ............. .30 2.00

C. Corulea. Bright blue;

C. Rosea. Deilicate rose ; 12 í

vutans Aiba. White ; very

N. Cor spikes. ……

very long spikes.......... . $30 \quad 2.00$

N. Rosea. Pink; long spikes $.50 \quad 3.00$

Pernvian Alba (White Cuban Lily) $\$ 0.20 \quad \begin{gathered}\text { Each } \\ \$ 2.00\end{gathered}$

Lutea (Yellow Cuban Lily) ...... $.50 \quad 5.00$

Corulea (Blue Cuban Lily) ..... $.30 \quad 1.75$

\section{SNOWDROPS}

\section{(Galanthus Nivallis)}

These lovely little flowers, the first to open in the Spring, should have a place in every garden. They are the hardiest of all bulbs, and can be found pushing their way through the snow in early Spring, flowering two weeks ahead of the Crocus. They thrive in almost any situation or soil ; standing more hard treatment than any other plant.

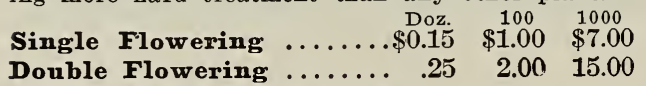

Double Flowering $\ldots \ldots \ldots$
GIANT S N O W D 0 P S

(Galanthus Elwesii). Flow-

ers three times as large as

the ordinary Single Snow-

$\begin{array}{llll}\text { drops, borne on long stems.. } & .20 & 1.25 & 8.00\end{array}$

\section{TRILLIUM. Wood Lily}

Hardy native flowers, excellent for shady places.

Grandiflorum (American Wood Doz. 100

Lily). Flowers pure white chang-

ing to delicate rose............ \$0.75 $\$ 5.00$

Snow Queen. Pure white; with

broad petals ................ 1.5010 .00

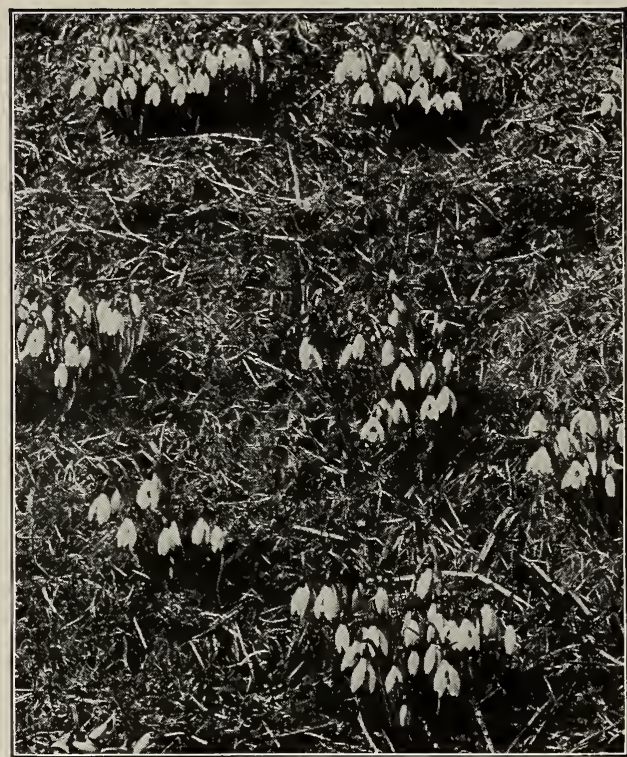

Snowdrops in Grass

TRITOMA

\section{Red-Hot Poker, Torch Lily or Flame Flower}

Beautiful hardy ornamental plants. Excellent for herbaceous borders with intense scarlet flowers.

Grandiflora $\ldots \ldots \ldots \ldots \ldots \ldots \ldots \ldots{ }_{\$ 0.15}^{\text {Each }} \begin{aligned} & \text { Doz. } \\ & \$ 1.50\end{aligned}$

Pfitzeri. A grand variety......... .20 2000

\section{TROPAEOLUM}

Charming climbing plants for the conservatory or window. Delicate foliage and elegant flowers.

Jarrattii (Tricolorum). Scarlet, yellow and black. Each 25c., doz. $\$ 2.50$.

\section{Bulbs for Wild Garden and Naturalizing}

The outlay being so small, it hardly seems possible that more people do not take advantage of improving bare spots among their shrubbery, and unsightly corners about their places, which may be done with little trouble when a continual succession of bloom may be had from early Spring until Fall.

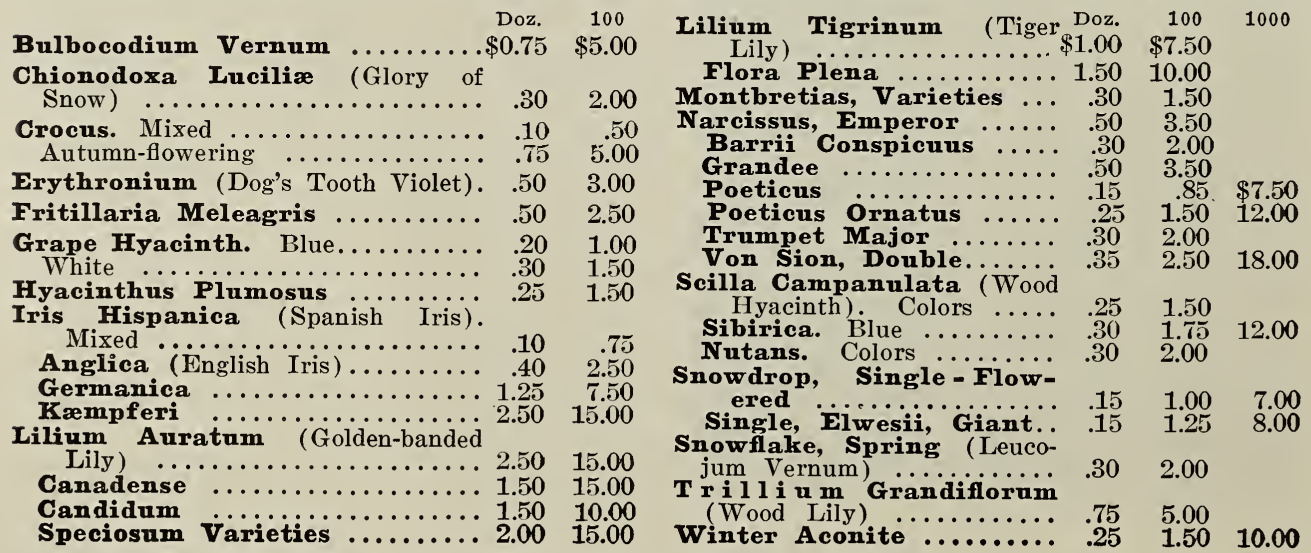




\section{RELIABLE FLOWER SEEDS}

\section{Suitable for Autumn Sowing}

\section{ASPARAGUS}

Plumosus Nanus. This graceful climbing plant has foliage finer than that of the most delicate fern. Extensively grown for bouquets and other decorations. 100 seeds $\$ 1.00$, pkt. 25c.

Sprengeri. A graceful drooping variety, used for hanging baskets. 100 seeds $50 \mathrm{c}$., pkt. $10 \mathrm{c}$.

\section{LAING'S BEGONIAS}

This superb strain of double and single Begonias which we now offer surpasses all other introductions.

Laing's Gold Medal, Tuberous-Rooted Single Hybrids. Mired. Pkt. $50 \mathrm{c}$.

Laing's Gold Medal, Tuberous-Rooted Double Hybrids. Mixed. Pkt. $75 \mathrm{c}$.

BEGONIA BULBS. See page 14.

\section{CALCEOLARIA HYBRIDA}

CHOICE SELECTED STRAIN. An ornamental plant, with beautiful pocket-like flowers; universally admired for decorating the greenhouse or conservatory. The strain we offer can be relied upon to produce flowers of the largest size and most brilliant colors. Pkt. 50c.

\section{CENTAUREA}

\section{WHITE-LEAVED VARIETIES}

Gymnocarpa. Silver gray foliage. Very graceful. Oz. $\$ 1.00$, pkt. $10 \mathrm{c}$.

Candidissima. Silver white, with deep cut foliage. 1000 seeds $\$ 1.00$, pkt. 10c.

Suaveolens (Yellow Sweet Sultan). Pkt. כॅc.

\section{CINERARIA HYBRIDA}

EXTRA CHOICE MIXED. Our strain of this seed we can highly recommend. The plants are of compact growth with fine cut foliage, flowers perfect in form and embrace all the most beautiful shades and colors. Pkt. 50c., large pkt. $75 \mathrm{c}$

Stellata. Fine for cutting. Flowers star-shaped. A very decorative pot plant. Colors, white, rose, red, carmine and blue mixed. Pkt. 25c.

Cineraria Maritima Candidissima (Dusty Miller). Yellow flowers, foliage silvery white. Oz. 50c., pkt. 5 c.

\section{CYCLAMEN}

PERSICUM GIGANTEUM (Superb Strain), Handsome greenhouse or parlor plants, with beautiful foliage and rich-colored, fragrant flowers; a universal farorite for Winter and Spring blooming. The Giant varieties have large leaves and stout flower stalks. throwing the flowers well above the foliage. Finest mixed colors. 100 seeds $\$ 1.00$, pkt. $50 \mathrm{c}$.

\section{GLOXINIA}

Charming greenhouse plants, producing magnifcent flowers of the most exquisite and gorgeous colors. 1 foot.

Large Flowering. Mixed. Pkt. 50c.

GLOXINIA BULBS. See page $\mathbf{1 5 .}$

\section{GREVILLEA}

GREVILLEA Robusta (Silk Oak). A beautiful decorative plant, with fern-like foliage; excellent for table decoration. 3 to 5 feet. $\mathrm{Oz}$. $\$ 1.00$, pkt. 10c.

\section{LOBELIA}

This plant will be found most desirable for pot culture, and hanging baskets, etc. $1 \frac{1}{2}$ feet.

Erinus. Deep blue. Pkt. 5c.

Crystal Palace Compacta. Dark blue. The hest for forcing or bedding. 6 inches. $1 / 8 \mathrm{oz}$. $50 \mathrm{c}$, pkt. $20 \mathrm{c}$.

Emperor William. Sky blue. Pkt. 10c.

Gracilis. Pale blue; trailing habit. Pkt. 5c.

Finest Mixed. Pkt. 5c.

Cardinalis Hybrida (Cardinal Flower). A hardy perennial, of various shades of scarlet. Pkt. 10c.

\section{MIGNONETTE}

NEW YORK MARKET (True). This Mignonette has proved superior to all others and is certainly the best variety grown for forcing. Its individual florets are exceedingly large, forming a graceful and compact spike. The fragrance is delightful. and for cutting it is perfection, remaining fresh from 8 to 10 days in water. Pkt. $50 \mathrm{c}$., $1 / 4$ oz. $\$ 2.00$.

Allen's Defiance (True). Pkt. 10c., oz. $\$ 1.00$.

Machet. Dwarf. Pkt. 10c., oz. 75c.

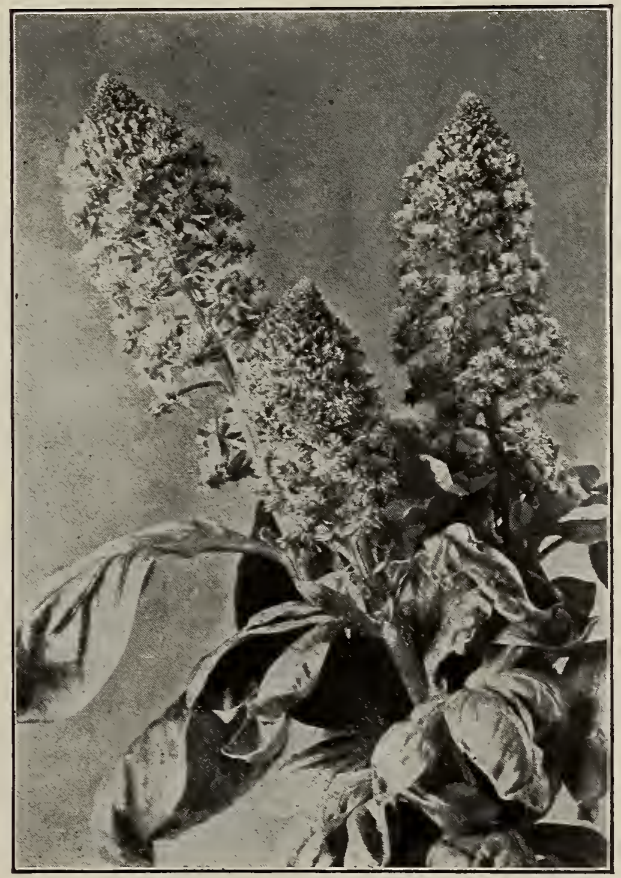

Mignonette New York Market 


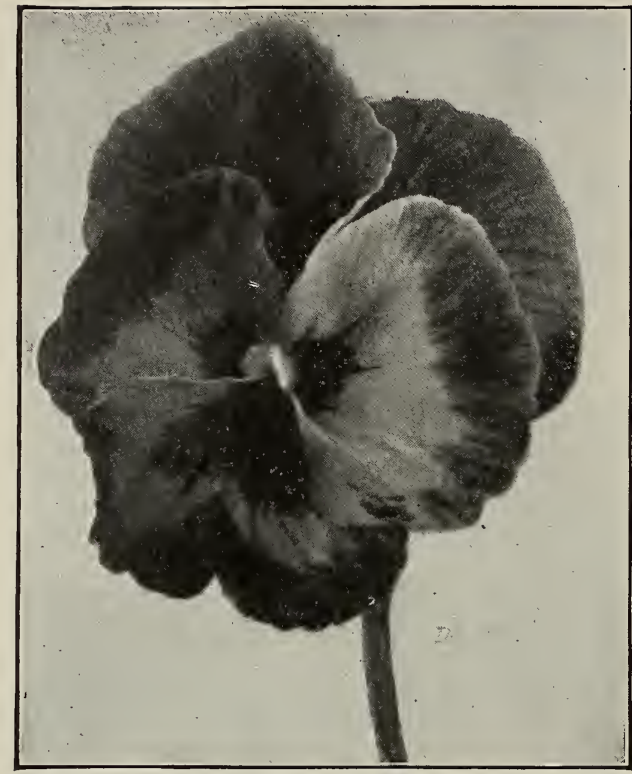

Pansy Burnett's Gorgeous

\section{PANSY}

BURNETT'S GORGEOUS STRAIN. The seed offered by us of this grand mixture contains a most beautiful collection of colors and markings not found in any other. For perfection of form, firmness of texture, freedom of bloom and beauty of shade, it excels all others. $1 / 4$ oz. $\$ 3.00$, pkt. 50c.

American Show, Extra Choice, Mixed. 1/4 oz. $\$ 2.00$, pkt. 25 c.

Masterpiece (Frilled Pansy). Petals beautifully waved. Mixed colors. Pkt. 25c.

\section{BURNETT'S GIANT PANSIES Pkt.}

Black. Dark and velvety............\$0.15

Striped. Very showy...............

White. With dark eye...............15

Yellow. With dark eye.............. 15

Emperor William. Ultramarine blue.... .15

Fire King. Mahogany and gold........... .15

Finest Mixed ................ $\$ 2.00 \quad .15$

Imported Collection of 6 Varieties.. .50

Imported Collection of 12 Varieties.. .75

\section{PETUNIA}

For outdoor decoration or house culture few plants equal Petunia in effectiveness. 6 inches.

Burnett's Double Fringed. Mixed. Flowers large, fringed; colors exquisite.......\$0.50

Hybrida Grandiflora. Choice double mixed .25

Collection of 6 Varieties. Double..... .75

Giant of California. Single. Flowers very large, with deep yellow throats..... . .25

Ruffled Giant. Single. Flowers large and beautifully fringed .................

Striped and Blotched. Single. Fine for massing ....................... $\$ 1.50$ Collection of 6 Varieties. Single..... .50

\section{PRIMULA}

The Sinensis and Obconica varieties of these beautiful flowers are indispensable for Winter or Spring decorations in the home or conservatory.

Single Large-Flowering Fringed Primula Sinensis Fimbriata

Alba. Pure white .......100 seeds 50c. $\$ 0.25$ Alba Magnifica. Pure white, with large yellow eye, beautifully fringed...........

Chiswick Red. Brilliant 100 seeds $50 \mathrm{c}$.

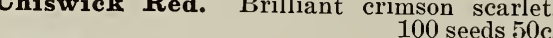
Rubra. Choice red........100 seeds 50c.

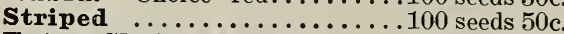
Extra Choice Mixed.........100 seeds 50c. Double Large-Flowering Fringed Primula Sinensis Fimbriata. Double red. $\quad .50$ Double White, Striped............Each $\quad .50$ Choice Mixed ................... .50 Stellata, Choice Mixed ................ Primula Obconica. Color delicate lilac.. .10 Obconica Grandiflora. Carminea, bril-

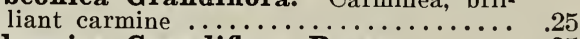

Obconica Grandiflora Rosea...........

Obconica Grandiflora. Choice mixed.. .25

\section{STOCK}

Burnett's Perpetual White. Seed of this Stock saved from plants grown under glass, will produce over 75 per cent. double flowers. Plants grow from 2 to $21 / 2 \mathrm{ft}$. high and throw up main flower spike of from 12 to 18 in. Unrivaled for forcing purposes. Pkt. 25c., large pkt. 50c.

Beauty of Nice. Very fragrant flowers of a delicate shade of fleshy pink. A good forcing variety. Pkt. 25c., large pkt. 50c.

Queen Alexandra. Of the same type as "Beauty of Nice"; flowers delicate rosy lilac. It will prove a splendid companion to the above. Pkt. 25c., large pkt. 50c.

\section{SWEET PEAS WINTER-FLOWERING VARIETIES \\ For Forcing}

Very early: seed sown September 1st will produce an abundance of bloom for Christmas. Flowers extra large on very long stems. New crop seed ready August 10th.

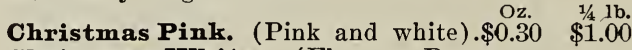
Christmas White. (Florence Den-

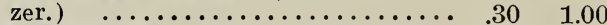

Le Marquis. Large, dark blue..... $\quad .30 \quad 1.00$

Mrs. Alex. Wallace. Lavender.... . .30 1.00

Mrs. Edie Wild. Carmine red.... $\quad .30 \quad 1.00$

Mrs. F. J. Dolansky. Pink . . . . . . . .30 1.00

Mrs. William Sim. Salmon pink.. $\quad .30 \quad 1.00$

Christmas-Flowering Mixed ... $\quad .30 \quad 1.00$

OTHER VARIETIES OF SWEET PEAS

See Spring Catalogue.

WALLFLOWER

Pkt.

Single Large-Flowering, Mixed. Oz. 40c. $\$ 0.05$ Double Large-Flowering, Mixed....... .15

Kewensis. Winter-Flowering, New. The flowers of this new hybrid are borne on long slender stalks and extremely fragrant. The colors vary from sulphur yellow to brownish-violet. From seeds sown in July or August plants will bloom early

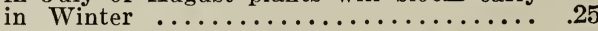

Flower seeds omitted from this list will be found in our General Spring Catalogue. 


\section{Hardy Perennial Flower Seeds}

\section{Suitable for Autumn Sowing}

Many varieties of Annuals and Perennials give better results when sown in the open ground in Autumn. Therefore, we give the following list, which will succeed well in this latitude and southward. Plants grown trom seed sown in the lall flower earlier and more numerously than if sown in Spring.

Achillea Ptarmica fl. pl., “The Pearl." $\$ 0.10$ Adonis Vernalis .................... 05 Alyssum Saxatile Compactum..Oz. 60c. .05 Aquilegia Vulgaris, Single Mixed.... Oz. 30c. .05

Double Mixed . Oz. 50c

Imported Collection of 6 Varieties. Imported Collection of 12 Varieties.

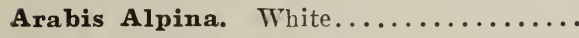
Asperula Odorata (Woodruff). White...

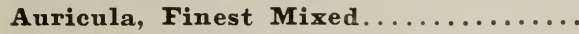
Baptisia Australis (False Indigo). Blue. Bocconia Japonica (Plume Poppy). White CANTERBURY BELLS-

Medium, Blue, White, Rose.....Each

Finest Double Mixed.............

Finest Single Mixed.......... Oz. 50c. Calycanthema (Cup and Saucer). Blue, Rose, White, Mixed.. Each, oz. $\$ 1.00$ Candytuft Sempervirens. White......

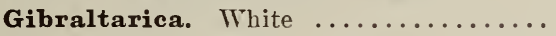
Centaurea (Cornflower). Blue.... Oz. 30c. Mixed .................... 25c. Odorata Margaritæ. White ........ Imperialis, Mixed .......... Oz. 50c. Clarkia Elegans, Mixed. ........ Oz. 30c. Coreopsis Lanceolata Grandiflora. Golden yellow hardy perennial.......... Oz. 75c. Cowslip (Primula Veris). Mixed....... Daisy (Bellis Perennis) -

Double Snowball. White...........

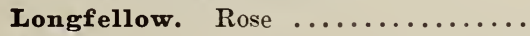
Mixed. Extra large.............

Delphinium Chinensis. Mixed...Oz. 50c.

Elatum. Blue ............. Oz. 50c.

Formosum. Deep blue.......... Oz. 75c. Cœlestinum. Celestial blue .........

Zalil (Sulphureum). Yellow..........

Large-Flowering Mixed ...... Oz. 50c.

Dianthus Plumarius (Pheasant's Eye. Pink) -

Single Mixed ...............

Double Mixed $\ldots \ldots \ldots \ldots \ldots \ldots \ldots \ldots . .25$

Semperflorens (Double Clore Pink).. .10

Digitalis (Foxglore). White. Rose, Purple. Mixed............. Each, oz. 40c.

Gloxinioides. Beautifully spotted large Gloxinia-shaped flowers ........ Oz. 50c.

Gaillardia Grandiflora ......... Oz. 50c. Grandiflora Maxima. Golden yellow.. Kelway's New Hybrids, Mixed....... Collection of 6 Varieties.......... .50
Gypsophila Paniculata (Baby's Breath).

Mist-like flowers, admired for bouquets....

Hollyhock Charter's-

Double White, Light Rose, Salmon and Bright Pink...Each, oz. $\$ 2.00$

Sulphur Yellow .......... Oz. 1.50 Mixed ................. . .75 $\quad .10$

Allegheny Mixed ............ $\quad .10$

Collection 12 Varieties............ 1.00

Collection 6 Varieties............ .60

Jacob's Ladder (Polemonium). Blue.... . .10

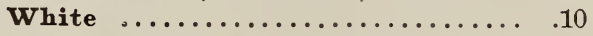

Lathyrus Latifolius (Everlasting Pea)Mixed ..................... . .0. 05

Linaria Cymbalaria (Kenilworth Iry) ... .05

Lobelia Cardinalis (Cardinal Flower) ... . .10

Lupinus. Perennial mixed.......... Oz. 30c. .05

Myosotis (Forget-Me-Not) -

Alpestris. Blue ............ Oz. 75с. .10 Alba. White ............ Oz. $\$ 1.00 \quad .10$

Victoria. Blue ............ Oz. 2.00 10

Palustris. Blue ................. 10

Mixed ..................... 75c. .05

Pentstemon Cobæa ............... .10

Mixed ........................ . .05

Phlox Decussata. Mixed............ .10

Large-flowered Mixed Hybrids.......... .25

Picotee (Carnation). Choice Double Mixed. .25

Vienna Strain, Mixed............ 10

Polyanthus. Finest mixed........... .25

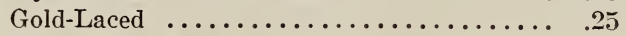

Poppy Orientale. Scarlet........... .10

Mixed Hybrids ................ 10

Nudicaule (Iceland Poppy). Scarlet ... .10

Mixed ................. Oz. $\$ 1.00 \quad .10$

Bracteatum. Scarlet .............. 10

Primula Vulgaris (Tellow Primrose).... . 10

Japonica. Mixed .............. 10

Forbesii (Baby Primrose) ........... .25

Rudbeckia Superba $\ldots \ldots \ldots \ldots \ldots \ldots \ldots . .05$

Newmani .....................

Snapdragon (Antirrhinum) -

New Large-Flowered Mixed. . Oz. $\$ 1.00 \quad .10$

Tall Mixed ................ Oz. 50c. .05

Dwarf, Queen of the North. White.. .10

Dwarf Mixed ............... Oz.50c. .05

Collection of 6 Varieties......... $\quad .30$

Collection of 12 Varieties.......... .50

Stokesia Cyanea (Hardy Blue Aster).... . .10

Sweet Rocket (Hesperis). Mixed........ .05

Sweet William, Single. Mixed..Oz. 40c. .05

Double. Mixed .............. Oz. 75c. .10

Hardy Perennials omitted from this list will be found in our Midsummer Catalogue which will be mailed free on application. 


\section{Reliable Vegetable Seeds}

\section{Suitable for Forcing and Outdoor Planting}

\section{ASPARAGUS ROOTS}

Can be planted either in Fall or Spring.

Conover's Colossal. Two-year-old roots. 100 75c., $1000 \$ 6.00$. Three-year-old transplanted roots. $100 \$ 2.00,1000 \$ 18.00$.

Palmetto. Two-year-old roots. $100 \$ 1.00,1000$ $\$ 7.00$. Three-year-old transplanted roots. 100 $\$ 2.00,1000 \$ 18.00$.

Columbian Mammoth White. Two-year-old roots. $100 \$ 1.00,1000 \$ 7.00$.

Bonvallet's Giant. Two-year-old roots. 100 $\$ 1.50,1000 \$ 10.00$.

\section{BEANS}

\section{Dwarf Green Podded}

Early Mohawk. Long, straight, flat pods ; early, and productive. Pt. $15 \mathrm{c}$., qt. $25 \mathrm{c}$., pk. $\$ 1.50$.

Black Valentine (Black Seeded). With long green, straight, fleshy pods; a splendid forcing variety. Pt. 20c., qt. 35c., pk. $\$ 2.00$.

Bountiful. Early and prolific, with long, flat, green pods; tender and stringless. Pt. $20 \mathrm{c}$, qt. 35 c., pk. $\$ 2.00$.

Giant Stringless Green Pod. Pods long; early and prolific. Pt. 20 c., qt. 35c., pk. $\$ 2.00$.

Ne Plus Ultra. Extra early; green, flat pods ; exceedingly productive; suitable for forcing. Pt. 20c., qt. 35c., pk. $\$ 2.00$.

Refugee, or 1000-to-1. Very productive. Largely grown in the Fall for pickling. Pt. 15c., qt. 25c., pk. $\$ 1.50$.

\section{BEETS}

Rurnett's Improved Crimson Globe. Fine globular shape; flesh rich, deep crimson; tender and sweet. Pkt. 10c., oz. 20c., 1/4 lb. 60c., lb. $\$ 2.00$.

Crosby's Egyptian. Dark blood red; flat in shape. Pkt. 5c., oz. 20c., $1 / 4$ lb. 60c. lb. $\$ 2.00$.

Detroit Dark Red. Color dark blood red; very tender; good for early or late sowing. Pkt. 5c., oz. 20c. ; $1 / 4$ lb. 60c., lb. $\$ 2.00$.

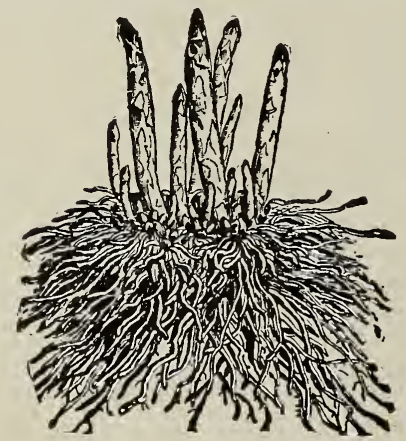

Asparagus Roots

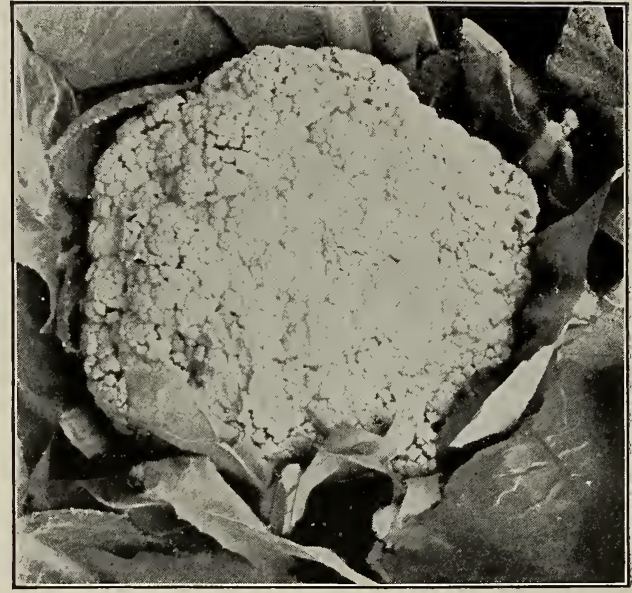

Cauliflower Snowball

\section{CAULIFLOWER}

Early Snowball Selected. This is the earliest and surest heading variety. Its dwarf habit and short outer leaves allow it to be planted very close. It is specially adapted for forcing or outdoor planting. Heads pure snow white. Pkt. 25 c., $1 / 4$ oz. $\$ 1.25$, oz. $\$ 4.00$.

Erfurt Earliest Dwarf. Good for forcing; grows very dwarf and compact, with short stem and small leaves. Pkt. 25c., oz. $\$ 5.00$.

\section{CARROT}

Paris Exhibition. This Carrot is an improved strain of the French type. The roots are small, globular in shape, fine grained and very delicate. Color bright orange; tops small. For forcing or growing in frames this variety will be found the most desirable. Pkt. 10c., oz. 40c., 1/4 lb. $\$ 1.25$, lb. $\$ 4.00$.

Early Scarlet Horn. The well-known standard variety. Pkt. 5c., oz. 20c., 1/4 lb. 70c., lb. $\$ 2.50$.

New York Market. Very productive; of a bright orange color; crisp, tender and sweet, almost coreless. Pkt. 5c., oz. 25c., $1 / 4$ lb. 85c., lb. $\$ 3.00$.

\section{CUCUMBER}

Perfection White Spine. An improved strain of White Spine; fruit uniformly large, of a rich, deep green color; the best for forcing or general use. Pkt. 10c., oz. 25c., $1 / 4 \mathrm{lb}$. 50c., lb. $\$ 1.50$.

ENGLISH FORCING VARIETIES

Telegraph, Marquis of Lorne, Duke of Edinburgh, Tender and True, Covent Garden Favorite, Lockies' Perfection. Each, pkt. 25c. 


\section{LETTUCE}

Balmoral. New. In recommending this grand new early head Lettuce we can safely say that for forcing or outside planting it is unequaled. The heads are of medium size and very solid; outer leares light green with golden yellow heart. It is crisp, tender and of perfect quality. Give it a trial and prove its excellence. Pkt. 10c., oz. 25̄c., 1/1 lb. 75c.

Big Boston. Heads double the size of Boston Market; the best variety for general purposes or forcing. Pkt. 5c., oz. 20c., $1 / 4$ lb. 50c., lb. $\$ 1.50$.

Boston Market. The standard sort; heads solid, crisp and compact; one of the best for forcing. I'kt. Jc., oz. $15 \mathrm{c} ., 1 / 4 \mathrm{lb}$. $40 \mathrm{c}$., lb. $\$ 1.25$.

Golden Queen. A grand forcing rariety, of a golden yellow color; heads medium sized, solid, crisp and tender. Pkt. 5c., nz. 20c., $1 / 4$ lb. 50c., lb. $\$ 1.50$.

\section{MUSKMELON}

Royal Jubilee Forcing. This Melon is unquestionably the finest rariety ever offered for forcing purposes. 'The fruit is large. of a light green color, perfectly round, and thickly corered with light netting. The flesh is from 2 to $21 / 2$ inches thick. Color greenish white and flavor delicious. I'kt. (12 seeds) 50c., 25 seeds $\$ 1.00$.

Blenheim Orange. Flesh scarlet. Pkt. 25c.

Countess of Lathom. Flesh green. Pkt. 25c.

Hero of Lockinge. Flesh white. Pkt. 25c.

Invincible Scarlet. Flesh deep scarlet. Pkt. $25 \mathrm{c}$.

Royal Favorite. Flesh white. Pkt. 25c.

Royal Sovereign. Flesh white, tinged with green. Plit. 2\%c.

Sutton's Al. Flesh scarlet. Pkt. 25c.

Emerald Gem. Fruit of medium size; skın smooth; orange flesh, rich and delicious; of a deep green color. A good forcer. Pkt. 10c., oz. $25 c ., 1 / 4 \mathrm{Ib}$. $75 \mathrm{c}$.

\section{MUSHROOM SPAWN}

Ten pounds will spawn 20 feet square

Mushrooms can be easily grown, with a little care and attention under benches in the greenhouse, in a cellar or any dark, dry place where a temperature of from 50 to 60 degrees can be maintained during the Winter months.

English Milltrack Spawn (in bricks). The best quality. Lb. $15 \mathrm{c}$., S lbs. $\$ 1.00$.

French Spawn. More bulky than the English, packed in boxes. 2-1b. boxes, 75c. each; in bulk, 35c. per lb.

American Pure Culture (in bricks). Lb. 15c., 8 lbs. $\$ 1.25$.

\section{PEAS}

Burnett's Extra Early Market. This Pea is unequaled for early use or general planting. Height, $21 / 2$ feet. Pt. 15c., qt. 30c., pk. $\$ 1.75$.

Gradus, or Prosperity. The most distinct Pea yet introduced. Pods rery large and well filled with large. wrinkled, deep green peas of the finest quality. 3 feet. Pt. 25c., qt. 50c., pk. $\$ 3.00$.

Sutton's Excelsior. The finest extra early, large-podded dwarf wrinkled Pea offered. 11/2 feet. Pt. 25c., qt. 40 c., pk. $\$ 2.50$.

\section{PARSLEY (NEW)}

BURNETT'S "EMERALD ISLE." This Parsley is of a beautiful dark green color and more densely curled than the older sorts. The plant is dwarf and rery compact, making it most desirable for planting indoors. Pkt. 10c., oz. 25c., $1 / 4$ lb. $75 \mathrm{c}$.

\section{RADISH}

\section{FORCING VARIETIES}

Rapid Forcing. Small, round, bright scarlet, with white tip, matures in 21 days; a splendid forcer. Pkt. 5c., oz. 10c., $1 / 1$ lb. 30c., lb. $\$ 1.00$.

Red Forcing. Extra early; round, bright red, with small tops: one of the best forcers. Pkt. 5c., oz. 10c., $1 / 4$ ib. 30c., lb. $\$ 1.00$.

Early Scarlet Globe. Color brilliant scarlet; flesh crisp and white; excellent for forcing. Pkt. 5c., oz. 10c., 1/t lb. 30c., lb. $\$ 1.00$.

\section{SPINACH}

Large-Leaved Viroflay (Thick-Leaved). A splendid sort for Fall sowing. Pkt. 5c., oz. 10c., $1 / 4$ lb. $15 \mathrm{c} ., 1 \mathrm{~b} .40 \mathrm{c}$.

Long-Standing. Dark green; leaves large and thick; best for Fall use. Pkt. 5c., oz. 10c., 1/4 lb. 15 c., lb. $40 \mathrm{c}$.

Prickly, or Winter. Tery ${ }^{\star h}$ ardy, highly recommended for Fall sowing. Pkt. 5c., oz. 10c., 1/4 lb. $15 \mathrm{c} .$, lb. $40 \mathrm{c}$.

\section{TOMATO}

Comet (True). A splendid forcing variety. It is rery short-jointed, fruiting close up to the stem. The tomatoes are of medium size, quite smooth. very solid. and of a deep scarlet color. Pkt. 25c., 1/t oz. \$1.25.

Best of All (Forcing). Sets freely and an immense cropper; color deep scarlet. Pkt. 10c., oz. 50c., $1 / 4$ lb. $\$ 1.50$.

Improved Lorillard (Forcing). Tery large fruit; color bright red; solid, smooth and fine flavored. Pkt. 10c., oz. 40c., $1 / 4$ lb. $\$ 1.25$.

Stirling Castle (Forcing). Fruit small, very solid and of excellent quality Pkt. 25c., oz. $\$ 1.50$. 


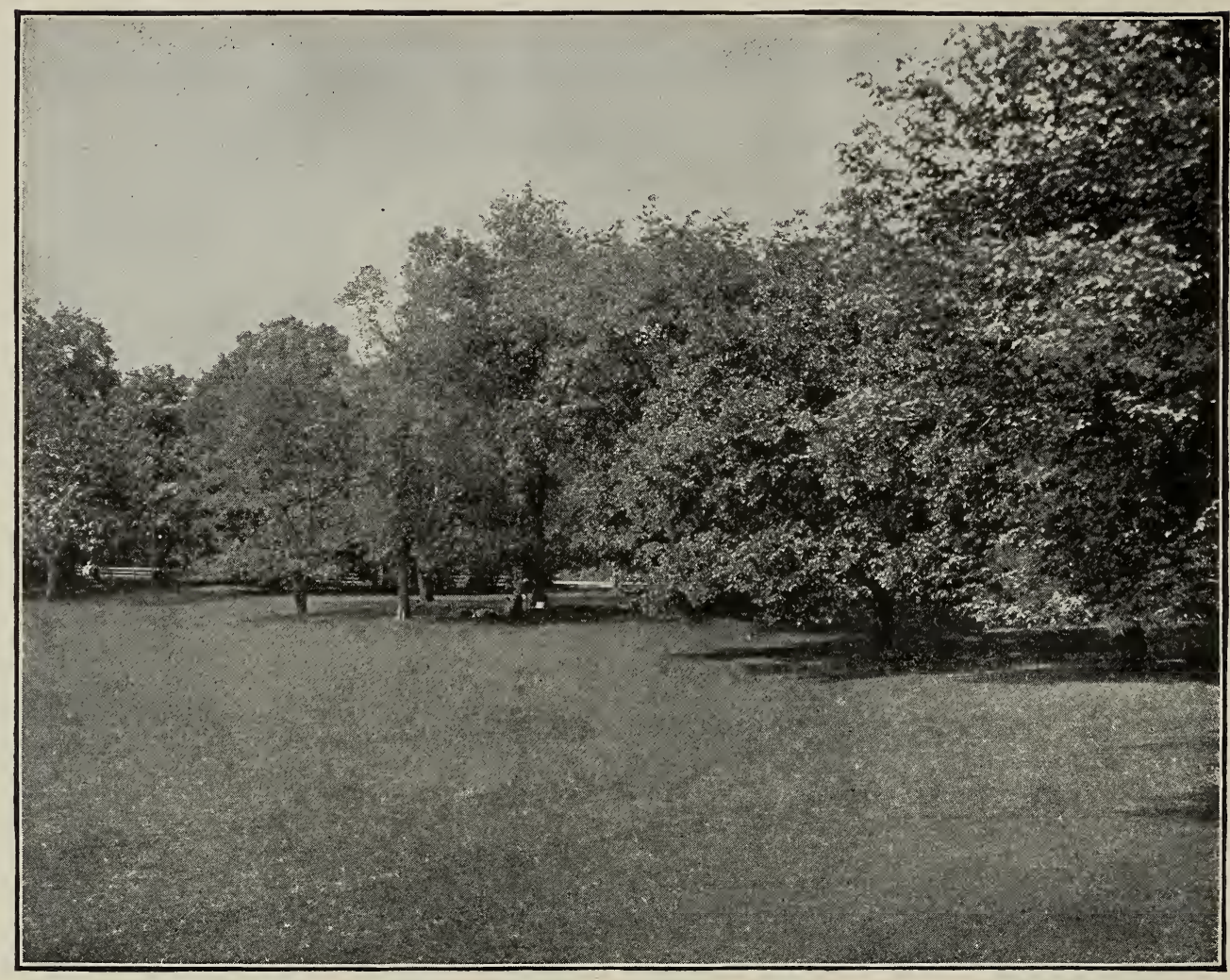

\section{LAWN GRASS SEED BURNETT'S SPECIAL LAWN GRASS MIXTURE}

The above mixture is made from our own formula, and composed of grasses specially adapted for the purpose of producing turf which retains its rich green color and velvety appearance throughout the entire Summer and Fall. In making up this high grade mixture we are careful to use only the very finest quality of all the most desirable dwarf evergreen, recleaned, grasses, free from chaff and weeds, which thrive well on any soil, thus ensuring a beautiful and permanent lawn.

To obtain good results Lawn Grass Seed should be sown as soon as the ground can be prepared in early Spring. It may also be sown in the Fall with good results. One quart will sow $15 \times 20$ feet (300 square feet); 1 bushel, $100 \times 108$ feet $(10,800$ square feet); 4 to 5 bushels to the acre.

Price: Qt. 25c., pk. $\$ 1.75$, bush. (20 lbs.) $\$ 6.00$.

\section{CENTRAL PARK LAWN GRASS}

This well-known mixture contains a large proportion of permanent grasses that grow quickly, producing a rich, green sward in about four weeks from time of sowing. Central Park is very hardy and has always given entire satisfaction in any location wherever sown. One quart will sow $15 \times 20$ feet; 1 bushel, $100 \times 108$ feet; 4 to 5 bushels to the acre.

Price: Qt. 20c., pk. $\$ 1.50$, bush. (20 lbs.) $\$ 5.00$.

Full directions for making a lawn printed on each box.

\section{GRASS SEED FOR BANKS AND TERRACES}

A mixture of grasses with long interlacing matting roots that will bind steep embankments, gravelly or sandy slopes, etc., preventing wash-outs by rainstorms and covering with permanently green turf. Price: Qt. $30 \mathrm{c}$., pk. $\$ 1.75$, bush. (20 lbs.) $\$ 6.50$.

\section{LAWN GRASS FOR SHADY PLACES AND UNDER TREES}

A selection of grasses that thrive well in shaded situations, under trees, or close to walls where there is little sun. Price: Qt. 30c., pk. $\$ 2.00$, bush. (20 lbs.) $\$ 7.00$.

\section{GOLF LINKS GRASS MIXTURES}

These mixtures will produce a tough, lasting sod that withstands extremes of heat and drought. Fair Green Mixture. Bush. (20 lbs.) $\$ 5.00$.

Putting Green Mixture. Qt. $30 \mathrm{c} .$, pk. $\$ 2.00$, bush. (20 lbs.) $\$ 7.00$. 


\section{BURNETT'S GRASS SEED MIXTURES FOR HAY, MEADOWS AND PERMANENT PASTURES}

These mixtures we have carefully prepared from the different perennial varieties of grasses, which are certain to give satisfactory results. They mas be sown either in the Spring or Fall, using three bushels of seed to one acre, with an additional ten pounds of mixed Clover sown early in the Spring. In ordering state whether for dry, wet, medium or heavy soil.

Permanent Pasture Mixture for high and $\operatorname{dry}$ soil, Per bus. of $18 \mathrm{lbs} \ldots \ldots \ldots \ldots \ldots$

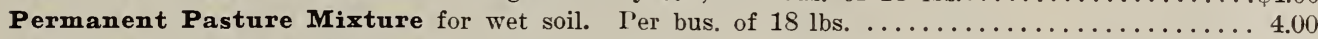

Permanent Pasture Mixture for medium soil. Per bus. of $15 \mathrm{lbs} \ldots \ldots \ldots \ldots \ldots \ldots$

Meadow Mixture. Made up specially for any soil or location. Per bus. of $18 \mathrm{lbs} . \ldots \ldots \ldots \ldots$

Burnett's Special Mixture for rough ground, woodlands, etc. Per bus. of 14 lbs..........

\section{BURNETT'S RECLEANED GRASS SEEDS}

All Grasses offered by us are of choicest quality, new crop seeds of high germination, entirely free from weeds.

Awnless Brome (Bromus inermis). Will stand long droughts and produce heary crops in dry sections. Lb. 22c., bus. (14 lbs.) \$2.75.

Canada Blue Grass (Poa compressa). For sowing on hard clay and poor soils. Lb. 20c., bus. (14 lbs.) $\$ 2.50$.

Creeping Bent Grass (Agrostis stolonifera). Excellent for lawns; succeeds nell in most situations. Lb. $45 \mathrm{c}$., bus. $(20$ lbs. $) \$ 8.50$.

Crested Dogstail (Cynosurus cristatus). Excellent for dry soils, pastures and lawns. Lb. 35 c., bus. ( 21 lbs.) $\$ 7.00$.

English Rye Grass (Lolium perenne). A very rapid-growing variety; valuable for meadows and pastures. Lb. 12c., bus. (24 lbs.) $\$ 2.50$.

English Rye (Paceys). A small seeded variety of the above, suitable for fine mixtures. Lb. 15 c., bus. (31 lbs.) $\$ 4.25$.

Fine-Leaved Sheep's Fescue (Festuca ovina tenuifolia). A fine-bladed grass, valuable only for lawns. Lb. 50c., bus. (14 lbs.) $\$ 7.00$.

Hard Fescue (Festuca duriuscula). One of the most desirable for dry soils. Lb. 35̌c, bus. (12 lbs.) $\$ 3.75$.

Hungarian Grass (Panicum Germanicum). A species of millet, but growing less rank; one
bushel per acre. Lb. 10c., bus. (48 lbs.) $\$ 2.50$.

Italian Rye Grass (Lolium Italicum). A valuable variety, adapted to any soil. Lb. 15c.,
bus. (18 lbs.) $\$ 2.50$.

Kentucky Blue Grass (Poa pratensis). Extensively used for lawns. Lb. 25c., bus. (14 lbs.) $\$ 3.00$.

Meadow Fescue (Festuca pratensis). Valuable for pastures; very productive. Lb. 24c., bus. (20 lbs.) $\$ 4.00$.

Meadow Foxtail (Alopecurus pratensis). One of the best pasture grasses. Lb. $40 \mathrm{c}$., bus. ( 7 lbs.) $\$ 2.75$.

Orchard Grass (Dactylis glomerata). Valuable for growing in shady, moist places, under trees, etc. Lb. 25 c., bus. (14 lbs.) \$3.25.

Red Top "Fancy" (Agrostis vulgaris). Recleaned seed, free from chaff. Lb. 25 c., bus. (30 lbs.) $\$ 7.00$.

Red Top "Common." Valuable for either pastures or lawns. Lb. 20c., bus. (14 lbs.) $\$ 2.50$.

Red, or Creeping Fescue (Festuca rubra). Taluable for lawns. Lb. 40c., bus. (14 lbs.) $\$ 5.00$.

Rhode Island Bent (Agrostis var.). Excellent for lawns or pastures. Lb. 50c., bus. (14 lbs.) $\$ 6.00$.

Rough Stalk Meadow Grass (Poa trivialis). Taluable for pastures and meadows. Lb. 55c., bus. (14 lbs.) $\$ 7.00$.

Sheep Fescue (Festuca ovina). Excellent for sheep pastures. Lb. 35̃c., bus. (12 lbs.) \$3.75.

Sweet Vernal Grass (Anthoxanthum odoratum). (True.) Should be sown with other grasses. Lb. $75 c$.

Tall Oat Grass (Avena elatior). Valuable for pastures. Lb. 30c., bus. (10 lbs.) \$2.75.

Timothy, or Herd Grass (Phleum pratensis). Generally grown for hay. $1 / 2$ bus. per acre. Lb. 12c., bus. (45 lbs.) $\$ 4.50$.

Wood Meadow Grass (Poa nemoralis). For lawns or pastures, also thrives well under trees. Lb. 55c., bus. (14 lbs.) $\$ 7.00$.

\section{CLOVER AND MILLET}

\section{Our Clover Seeds are all recleaned and of the finest samples.}

Alfalfa, or Lucerne (Medicago sativa). A valuable forage plant. Quantity to acre, 15 to 20 lbs. Lb. 30c., 100 lbs. $\$ 25.00$.

Alsike (Trifolium hybridum). Quantity to acre, 15 lbs. Lb. 35c., 100 lbs. $\$ 32.00$.

Crimson, or Scarlet Clover (Trifolium incarnatum). Valuable for green forage. Quantity to acre, 20 lbs. Lb. 15 c., 100 lbs. $\$ 12.00$.

Mammoth Red, or Pea Vine. Much taller than Medium Red. Good for ploughing under. Quantity to acre, 15 lbs. Lb. 35c., 100 lbs. $\$ 32.00$.

Medium Red (Trifolium pratense). Largely grown for general purposes. Quantity to acre, 15 lbs. Lb. 32c., 100 lbs. $\$ 30.00$.
Mixed Clover. Quantity to acre, $15 \mathrm{lbs}$. Lb. 35c., 100 lbs. $\$ 30.00$.

White Clover (Trifolium repens). The best variety for lawns. Quantity to acre, $10 \mathrm{lbs}$ Lb. 60c.. 100 lbs. $\$ 55.00$.

Yellow Trefoil (Medicago lupulina). For pastures, wet meadows or stiff soils. Quantity to acre, 15 lbs. Lb. 30c., 100 lbs. $\$ 25.00$.

\section{MILLET}

One bushel will sow one acre.

German, or Golden. Bus. (48 lbs.) $\$ 2.50$.

Hungarian. Bus. (48 lbs.) \$2.50.

Japanese. Lb. 10c., 100 lbs. $\$ 7.50$

Pearl, or Egyptian. Lb. 15c., 100 lbs. $\$ 12.00$.

Above prices subject to market changes. Special quotations on large quantities. GRANDIFLORA types of American and English origin. See our Spring Catalogue. 


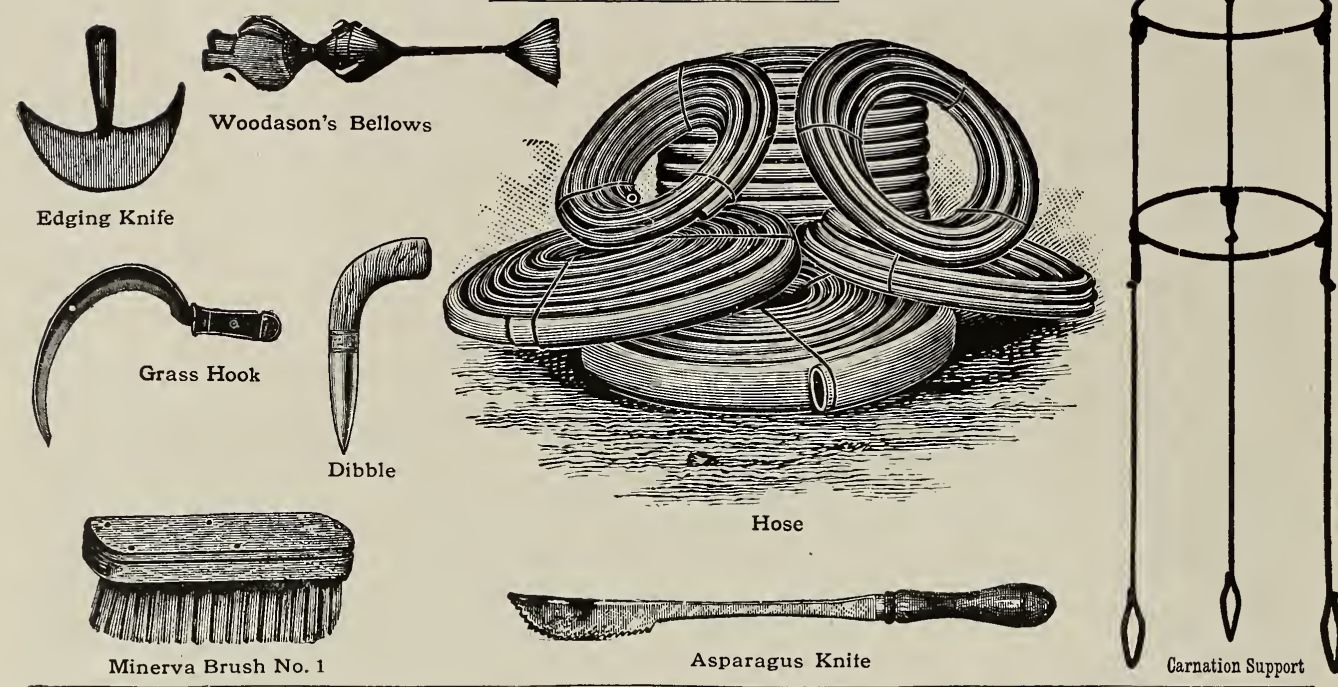

\section{GARDEN TOOLS AND SUNDRIES}

Asparagus Buncher. Watts' ....... Each

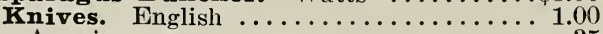

American ..................................

Bellows, Woodason's Powder.

Double cone $\ldots \ldots \ldots \ldots \ldots \ldots \ldots \ldots \ldots . . \ldots \ldots$

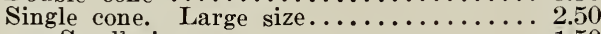
Small size .................. 1.50

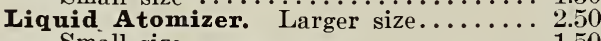
Small size .................... 1.50

Baskets, Rustic Hanging. 8 in. $\$ 1.00$, 10 in. $\$ 1.25,12$ in ............... 1.50

Baskets, Orchid. Made of red cherry wood. 6 in., each 35c., doz. $\$ 3.75$; 8 in., each 45 c., doz. $\$ 4.75 ; 10$ in., each 55 c., doz. $\$ 6.00 ; 12$ in., each $65 \mathrm{c}$., doz. $\$ 7.00$.

Bill Hooks, "English." Light \$1.25, heavy 1.50

Boots, Horse Lav'n. Made of heavy leather. Price, set of four, $\$ 9.00$.

Brushes, or Flower Pot Scrubbers. Made of coir fibre........... Doz. $\$ 1.50$

Flower Pot, Cone-Shaped. Made of

Mristle, wood handle................. the finest Scotch wire used for cleaning trees and general purposes. (See cuts.) No. 1. Coated wire, $11 \frac{1}{2}$ in. cut....... 3.00

No. 2. Coated wire, $11 / 2$ in. cut....... 3.00

No. 3. Coated wire, $11 \frac{1}{2}$ in. cut....... 3.50 Length over all 14 inches.

Carnation Supports. Model extension 2 ring, doz. 50c., $100 \$ 3.50$. 3 ring, doz. 60c., $100 \$ 4.00$.

Dibbles. Medium or large............. .40

Forks, Digging. Best make, 4 prongs ..... 1.25 5 prongs ........................... 1.50

Forks, Manure. Best cast steel, 4 prongs. 1.00 5 prongs ................... 1.25

Forks, Weeding. English strawberry, with short handles ..............50c. and

Fumigator, Campbeil's Patent Sulphur Vaporizer. An English apparatus designed to safely vaporize sulphur in greenhouses, to kill Mildew and other fungoid diseases affecting Roses, Vines, Cucumbers, Tomatoes, Chrysanthemums, Strawberries, Peaches, etc. ; also destroys Red Spider infesting Vines, Crotons, Asparagus Fern, and other plants. Prices, No. 1, vaporizing $3 \mathrm{oz}$. of sulphur, $\$ 6.50$; No. 2, vaporizing 6 oz. of sulphur, $\$ 8.00$. Full directions for use with each apparatus.
Fumigator, The Eureka. For fumigating Each

greenhouses, conservatories, etc.

No. 1. Height 12 in., holds $1 / 2$ peck of stems. $\$ 1.75$ $\begin{array}{lllll}2 . & 16 & \text { " } & 1 & 1 \\ 3 . & 20 & \text { " } & 1 / 2 \text { bush. of stems. } 2.75 \\ 4 . & 24 & 24 & 3.50\end{array}$

Fruit Picker, The Perfect. Made of galvanized steel wire; without pole..... .40

Gardener's Gloves. Per pair, $\$ 1.25$ to $\$ 2.50$.

Garden Lines, Braided. $100 \mathrm{ft}$. 75 c., 150 ft. $\$ 1.00,200 \mathrm{ft} . \$ 1.50$.

Garden Reels. Malleable iron....75c. and 1.00

Glazing Points (Van Reyper's). Per $100075 \mathrm{c}$.

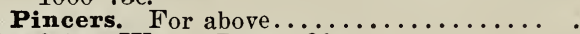

Grafting Wax. Per $1 \mathrm{~b} .30 \mathrm{c}$

Grass Edging Knives, "English." Handles 15c. extra. 8 in. $\$ 1.50,9$ in. $\$ 1.75$, 10 in. ............................

American. With handles.

Grass Hooks, or Sickles. English, $60 \mathrm{c}$., $75 \mathrm{c}$. and $\ldots \ldots \ldots \ldots \ldots \ldots \ldots \ldots \ldots \ldots \ldots . \ldots \ldots$

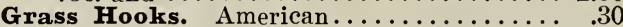

Hoes, Draw. With handles, 5 in. $35 c ., 6$ in.

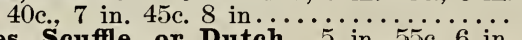

Hoes, Scuffle, or Dutch. 5 in. $55 \mathrm{c} .6$ in 60 c. 7 in., 65c., 8 in. 70 c., 9 in. 75 c., 10 in. 80 c., 12 in. 90 c. Handles $15 \mathrm{c}$. extra.

Hoes, Warren. Medium 65c. large........

Hose, Rubber. We offer the following standard high grade brands in 50 and 100-foot lengths.

Wizard. 3-ply, $3 / 4$ inch ........ \$0.12

Wallabout. $3-$ ply, $3 / 4$ inch........ 15

Tiger. 3-ply, 3/4 inch...........

Service. $3 / 4$ inch .............. 18

Electric. $3 / 4$ inch $\ldots \ldots \ldots \ldots \ldots \ldots . .20$

.75 Hose Reels. ${ }^{4}$ Wooden............ $\$ 1.50$ to 3.50

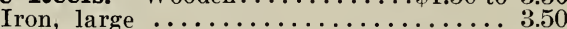
Iron, small $\ldots \ldots \ldots \ldots \ldots \ldots \ldots \ldots \ldots . \ldots \ldots$

Hose Menders.

Cooper's. $3 / 4$ in ........... Doz $\$ 1.00 \quad 10$

Hose Nozzles, Brass. With spray tip, $3 / 4$ inch 75c., 1 inch................. 1.00

Graduating Spray $\ldots \ldots \ldots \ldots \ldots \ldots \ldots . .50$

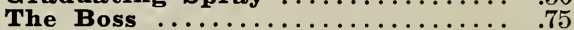

Hose Couplings ............ Per pair, 25 c. Washers. Doz. $10 \mathrm{c} ., 10075 \mathrm{c}$.

Hotbed Sash. Burnett's reinforced, $3 \times 6 \mathrm{ft}$ Painted and glazed............Doz. $\$ 48.004 .25$ Other Sash Frames, etc., see page 30 . 


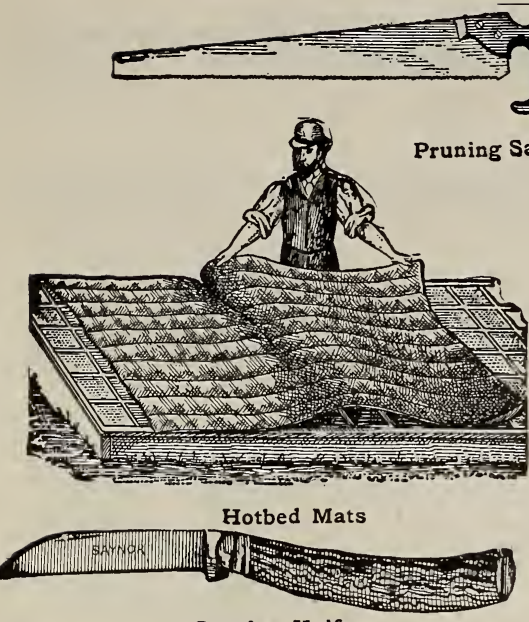

Pruning Knife

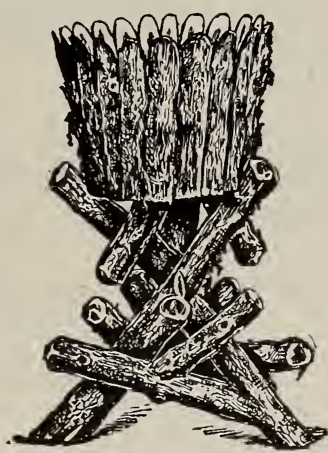

Rustic Vase

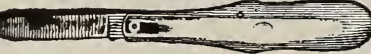

Budding Knife

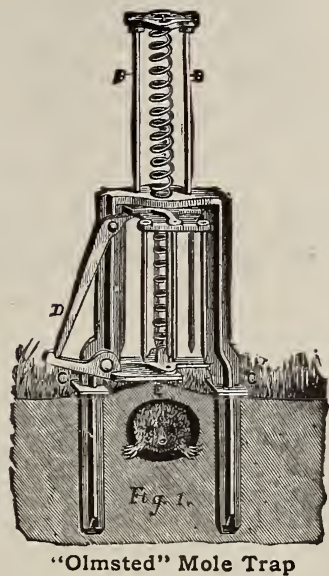

"Olmsted" Mole Trap

\section{GARDEN TOOLS AND SUNDRIES-Continued}

Knives, Budding, Saynor's. No. $1, \$ 1.50$; $2, \$ 1.50 ; 3, \$ 1.50 ; 4, \$ 1.50 ; 5, \$ 1.35 ; 6$, $\$ 1.50 ; 2$ blades, brass finish......... $\$ 2.50$

Knives, Pruning, Saynor's. No. 7, $\$ 1.40$; $8, \$ 1.25 ; 9, \$ 1.50 ; 10, \$ 1.40 ; 11, \$ 1.40$; $12, \$ 2.00 ; 13, \$ 1.50 ; 14 \ldots \ldots \ldots \ldots \ldots .1 .50$

Labels, Wooden, Pot and Garden. $\begin{array}{lllll}\text { Unpainted } & 100 \quad 1500 \quad \text { Painted } & 100 \quad 1000\end{array}$ 4 -inch. . . . \$0.10 $\$ 0.60 \quad 4$-inch. . . . $\$ 0.15 \$ 0.90$ 5 -inch...... $.15 \quad .90$ 6-inch..... $\quad .20 \quad 1.00$

8 -inch...... $.50 \quad 4.00$ 10 -inch..... $.55 \quad 4.50$ 12 -inch.... $.60 \quad 5.00$ 5 -inch..... $.20 \quad 1.25$ 6-inch..... $.25 \quad 1.35$ 8 -inch...... $.50 \quad 4.00$ $\begin{array}{rrr}8 \text {-inch...... } & .50 & 4.00 \\ 10 \text {-inch.... } & .65 & 5.00\end{array}$ 12 -inch. $.70 \quad 6.00$

Labels, Wooden Notched Tree.

$$
- \text { Onpainted } \longrightarrow \overbrace{100}^{- \text {Painted- } 1000}
$$

$31 / 2$-inch $\ldots . . . . . \$ 0.10 \$ 0.60 \$ 0.15 \$ 1.00$

$31 / 2$-inch (copper wired). $.20 \quad 1.75 \quad .30 \quad 2.25$

Labels, Zinc Garden. Per 100, No. 1 $\$ 2.00,2 \$ 1.75,5 \$ 1.75,6 \quad \$ 1.50,7 \$ 1.25$ $13 \$ 1.50,14 \$ 1.00,15 \$ 1.25,21 \$ 1.75$.

Indelible Ink for above. Per bottle, 25c. Indelible Pencils. For marking on wood.

Mastica. For glazing greenhouses. Per gallon, $\$ 1.40$.

Glazing Machine . . . . . . . . . . 1.35

Match Sticks. 18 inches long. Per 1000, $\$ 1.50$.

Mats, Frost-Proof, Burlap. $76 \times 76$ in. square; made of strong burlap cloth, filled with wool..........Doz. $\$ 16.001 .50$

Waterproof Duck. Filied same as above, with waterproof duck cotton cloth on one side. Size $76 \times 76$ in... Doz. $\$ 22.002 .00$

Straw. For covering sashes, etc. $6 \times 6 \mathrm{ft} .1 .75$

Mattocks and Picks. IVith handles...... $\mathbf{1 . 2 5}$

Mole Traps, New Model........... 1.50

olmsted's Improved ................ 1.50

Melon Nets. Made of fine cord for holding fruits ................. Doz. $\$ 1.50$

Paper, Cream Manila. $24 \times 36$. Lb. 7 c.

Tissue, Ream (480 sheets) $24 \times 36, \$ 2.00$.

Waxed Tissue. Ream (480 sheets) $24 \times 36$ in., $\$ 4.00$.

Coarse. For parceling. Lb. 8c.

Plant Sprinklers (Scollay's) Rubber. Large size .................... 1.00 The Lenox $\ldots \ldots \ldots \ldots \ldots \ldots \ldots \ldots \ldots \ldots \ldots \ldots \ldots \ldots \ldots \ldots . .35$

Potato Hooks. Fiat prongs. 4-prong $60 \mathrm{c}$,

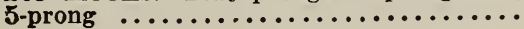
.15
Pruner, Eagle Tree. Cuts easier than any other. 2 -ft. handle $\$ 1.25$, 3-ft. handle... $\$ 1.50$

Waters' Tree. 6 ft. 90 c., 8 ft. $\$ 1.00$, $10 \mathrm{ft} . \$ 1.15,12 \mathrm{ft} . \ldots \ldots \ldots \ldots \ldots \ldots \ldots . . .25$

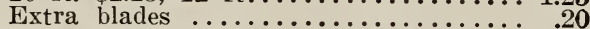

Little Giant Hook and Saw Combined. Attaches to pole of any length.. 2.00

Putty, Twemlow's Old English. Gal.

cans ..................... 1.25

Bulb, Rubber, Scollay's. For glazing.. 1.00

Raffia. For tying plants. Lb. 25c.

Rakes, Reversible Galvanized......... .75

Steel Garden. 8 teeth $40 \mathrm{c}$, 10 teeth $45 \mathrm{c}$. 12 teeth 55c., 14 teeth 65c., 16 teeth 75c., 18 teeth $\ldots \ldots \ldots \ldots \ldots \ldots \ldots \ldots$

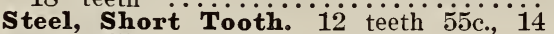
teeth 65 c., 16 teeth................

Wooden Hay. 3 bow, 12 teeth............

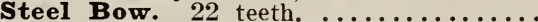

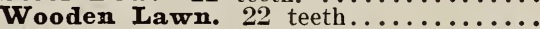

Rifles, Emory. For sharpening. Small 15c.,

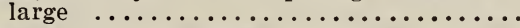

Rollers, Iron Garden and Lawn. See Page 86.

Rustic Hanging Baskets. Prices, 8 in. $\$ 1.00,10$ in $\$ 1.25,12$ in 1.50

Chairs. Ornamental ................ 4.00

Tables. (Round). Very strong........ 4.00

Settees. Strong and durable.......... 8.00

Garden Vases. Diameter 16 in., $31 / 2 \mathrm{ft}$ high. Pair $\$ 7.50 \ldots \ldots \ldots \ldots \ldots \ldots \ldots .4 .00$

Saws, Pruning. Single edge, 16 in. 75c., 18 in. 90c., 20 in ............... 1.00 Double edge, 16 in. $85 \mathrm{~s} .$, is in. $\$ 1.00$,

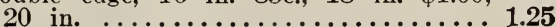

Scissors, Flower Gatherers. Best quality. 6 in. $\$ 1.25,7$ in. $\$ 1.50,8$ in.... 1.75

Propagating $\ldots \ldots \ldots . . . . . . . . .1 .00$

vine. Imported. 6 in. $\$ 1.00,7$ in. $\$ 1.25$, 8 in. ........................... 1.50

Shovels. Ames' extra quality. Square and round-pointed, long and short handles.. 1.50 Good quality. Square and round-pointed,

long and short handles............. 1.25

"Electric" Solid Socket." Square and round-pointed .................... 1.50

Sieves, Wire. For sifting loam, gravel, etc. ; from 16 to 20 in. in diameter..... 1.50 silkaline, Green. Per ib. $\$ 1.00$, spooi..... 25 Smilax Twine. Per hall 10c., doz. $\$ 1.00$. 

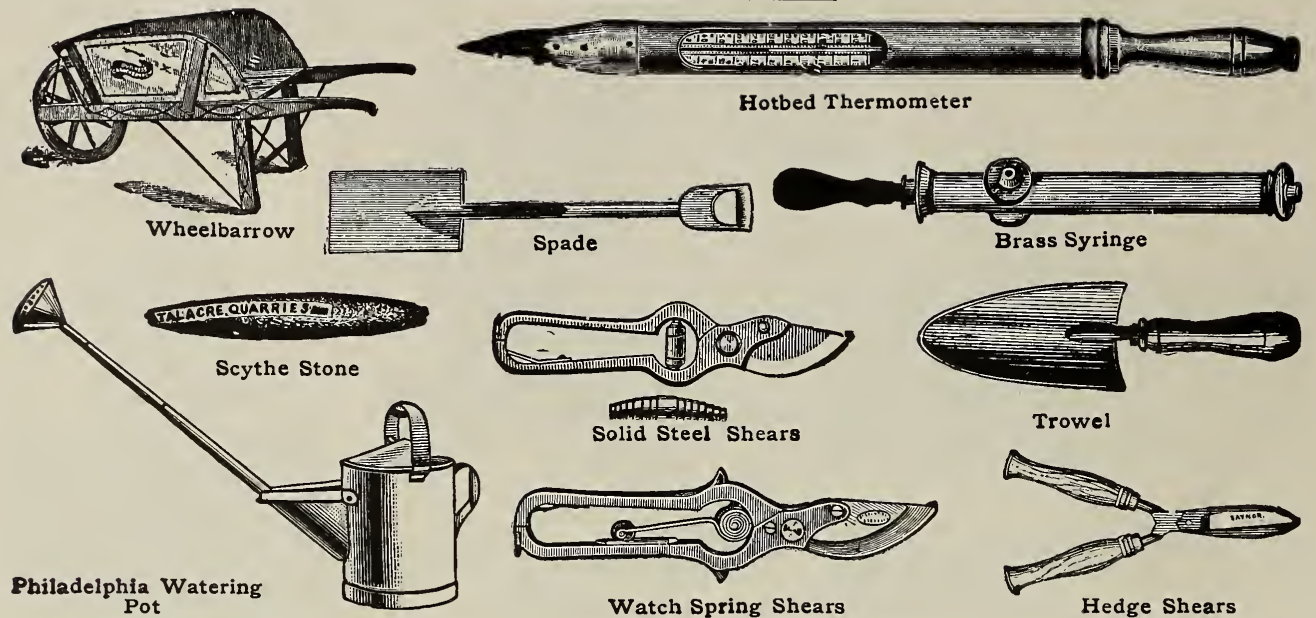

\section{GARDEN TOOLS AND SUNDRIES-Continued.}

Scythe, Lawn. English. Broad blades, 30

Each

to 40 in .................... \$1.50

Grass. American. 30 to 40 in......... 1.00

Snaths (or handle). Patent fastening.. 1.00

Stones, Scythe. Round "Talacre" 15c., flat. .10

Shears, Border. English. 8 in. $\$ 2.25,9$ in. $\$ 2.50,10$ in .................... 3.00

With wheel. 9 in. $\$ 3.00,10$ in....... 3.50

Hedge (with notch, 25c. extra). 8 in. $\$ 1.75,9$ in. $\$ 2.00,10$ in .......... 2.25

Hedge, The "Neverslip" (Self-sharpening). 8 in. $\$ 2.00,9$ in. $\$ 2.25,10$ in.... 2.50

Wiss' Hand-Pruning (Solid steel). 9 in. $\$ 2.50,10$ in ................ 3.00

Perfection Hand-Pruning. Made of the best steel and cuts on both sides. $7 \frac{1}{2}$ in. $\$ 2.00,81 / 2$ in. $\$ 2.50,91 / 2$ in..... 3.00

I a nd-P r uning Watch Spring "French." 7 in. $\$ 1.75,8$ in. $\$ 2.00$,

9 in. ...................... 2.50

Hand-Pruning, "Ladies." 50c., 75c. and 1.00

Sheep, or Grass. Trowel shank...75c. to 1.00

Various sizes...............50c. to .75

Spades. Ames' extra quality, long and short handles ..................... 1.50

Good quality, long and short handles.... 1.25

"Electric" Solid Socket. Long and

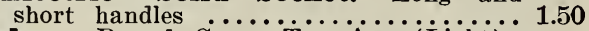

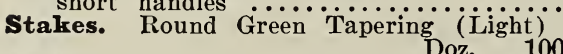

$11 / 2$ feet $\ldots \ldots \ldots \ldots \ldots \ldots \ldots \ldots \ldots . \$ 0.25 \quad \$ 1.20$

${ }_{2}^{11 / 2}$ feet $\ldots \ldots \ldots \ldots \ldots \ldots \ldots \ldots \ldots \ldots \ldots+.25 \quad \$ 1.20$

3 " $\quad \cdots \ldots \ldots \ldots \ldots \ldots \ldots \ldots \ldots \ldots \ldots \ldots \ldots, .60 \quad 4.75$

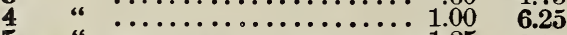

Stakes, or Dahilia $\ddot{\mathbf{P}}_{01 \mathrm{es}}$ Heavy. 1.25

4 feet $\ldots \ldots \ldots \ldots \ldots \ldots \ldots \ldots \ldots \ldots \$ 1.25 \quad \$ 7.50$

4 feet $\ldots \ldots \ldots \ldots \ldots \ldots \ldots \ldots \ldots . \$ 1.25 \quad \$ 7.50$

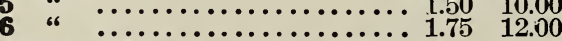

Stakes, Bamboo, Cane. From 5 to $8 \mathrm{ft}$ in length. $100 \$ 1.25,1000 \$ 10.00$.

stakes, Galvanized Wire. For roses, etc. Strong and durable. No. 9 wire.

2 feet.....\$1.75 4 feet.....\$2.25

$21 / 2$. $\ldots \ldots \ldots 1.85$

5 “ $\ldots .2 .50$

Gulphur Dusters. Boitte a Hauppe..... 1.00
Syringes, Brass Garden.

Each

No. 1. Length of barrel 12 in. diameter,

$11 / 8$ in., with one spray rose and stream. $\$ 3.00$

No. 2. Length of barrel $141 / 2$ in. diameter

$13 \%$ in., with one spray rose and stream. . 4.50

No. 3. Length of barrel 18 in., diameter $11 / 2$ in., with two spray roses and stream. 6.50

No. 4. Length of barrel 18 in., diameter $11 / 2$ in., with ball valve, two spray roses and stream ................. 7.00

No. 6. Length of barrel 16 in., diameter $1 \frac{1 / 2}{2}$ in., with one spray rose........... 2.50

Thermometers.

Japan, tin case, 6 to 12 in.......15c. to .30

Copper case ...............50c., 75c., 1.00

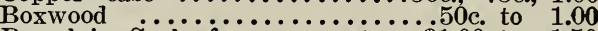

Porcelain Scale for conservatory. $\$ 1.00$ to 1.50

Self-registering (maximum and minimum). 3.00

Mushroom bed, boxwood, brass tips. 20 in. 2.50

Tin Foil. Lb. 25c., 100 lbs. $\$ 18.00$. Violet. Lb. $\$ 1.00$.

Tooth Picks for Stemming. Doublepointed, hard wood. Box 15c., doz. \$1.50.

Torches, Asbestos. Handles 15c., extra.. .35

Tree Guards. Made of strong steel wire, with three iron supports............2.00

Tree Scrapers, or Trianguiar Hoes....

Trowels. Forged steel. 6 in. $45 \mathrm{c}$, 7 in.

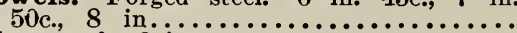

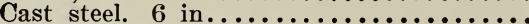

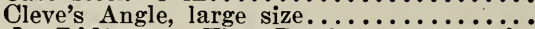

Tub Lifters. The Dowlen pattern for carrying heavy plants. Pair. $\$ 3.00$.

Turfing Iron or Sod Cutter, English. . 5.00

Twine, Marline. (Tarred twine). Lb. 25c. Hemp. All sizes. Lb. $30 \mathrm{c}$., to $40 \mathrm{c}$.

Jute. 3 and 4-ply for trees. Lb. 25c

Watering Pots, Galvanized Iron. Extra strong, with rim round the bottom. 6 qts. $\$ 1.50,8$ qts. $\$ 1.75,10$ qts. $\$ 2.00,12$ qts.

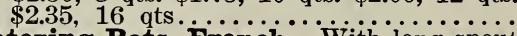

Watering Pots, French. 'With long spout and brass bow handle. 6 qts. $\$ 2.50$,

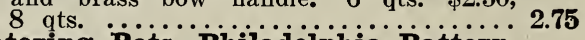

Watering Pots, Philadelphia Pattern. With two copper-faced roses. 4 qts. $\$ 2.25,6$ qts. $\$ 2.35,8$ qts. $\$ 2.50,10$ qts.

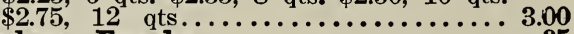

Weeders, Eureka $\ldots \ldots \ldots \ldots \ldots \ldots \ldots \ldots \ldots \ldots . .35$

Excelsior $\ldots \ldots \ldots \ldots \ldots \ldots \ldots \ldots \ldots \ldots \ldots \ldots \ldots, .10$

Long-handled, chisel-bladed $\ldots \ldots \ldots \ldots \ldots \ldots$. 35

Wheelbarrows. For garden use, No. $\dot{1}$, boys' size, $\$ 3.00 ; 2$, small........... 3.50

No. 3 , medium, $\$ 4.00 ; 4$, large......... 5.00 


\section{SPRAY PUMPS AND SPRINKLERS}

\section{"POMONA"BARREL SPRAY PUMP}

The" Pomona" Sprayer is recognized as the most

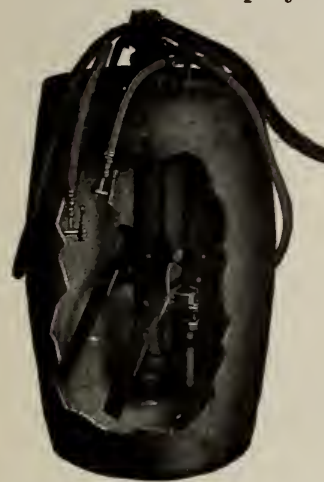
durable Barrel Sprayer on the market. It is unusually powerful, fully capable of supplying four leads of hose and eight nozzles. The working parts, including the plunger, plunger connections, glands, valves, valve seat, and strainers, are of solid bronze. They are simple, accessible and easily removed.

The agitator is simple but very effective, operated by the same lever that works the sprayer it agitates the liquid with every stroke.

"Pomona" Barrel Spray Pump Outfit C, Pump with Agitator, one lead i5 feet, Discharge Hose and Nozzle........

Outfit D, Pump with Agitator, two leads, Hose and two Spray Nozzles..........22.00

Barrel Cart furnished for above without

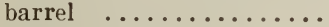

Extra barrel for above, each, $\$ 3.00$.

\section{GOULD'S BRASS BUCKET PUMP}

For spraying in gardens and greenhouses. The pump is double-acting in effect, has gutta percha ball valves, proof against the action of acids and oils. The pump end of discharge hose is wire wound, adding largely to its durability. Price, $\$ 5.00$.

GOULD'S "COMBINATION" KNAPSACK SPRAYER

Simple in construction. For greenhouses, for whitewashing fences, interiors of barns, stables, etc., as well as for spraying purposes. Price, with 4 feet $3 / 8$ inch discharge hose, Mistry or Mistry Jr. nozzles and extension, $\$ 10.00$.

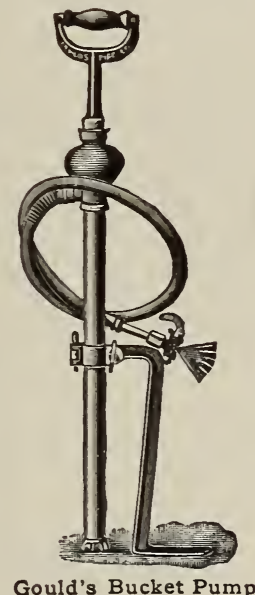

\section{"PLANET JR." FARM}

No. 11 Planet Jr. Double Wheel Hoe

One pair 6-in. Hoes: one pair 4-in. Hoes; two pairs Hollow Steel Cultivator Teeth; one pair Plows: two 3-Tooth Rakes: two 5-Tooth Rakes, and two Leaf Lifters; with attachments, \$9.50.

No. 12 Planet Jr. Double Wheel Hoe

One pair of 6-in. Hoes; two pairs of hollow steel Cultivator Teeth; one pair of Plows, and one pair Leaf Lifters; with attachments, \$7.25.

No. 16 Planet Jr. Single Wheel Hoe,

Cultivator, Rake and Plow

Two 6-in. Hoes, three Cultivator Teeth, one 7 inch and one 4-in. Rake, a large Garden Plow and a Leaf Guard. Price, $\$ 6.00$.

"Planet Jr," No. I 3 Double Wheel Hoe. Price, \$5.00

"Planet Jr." No. 18 Single Wheel Hoe. One pair 6-in. hoes only. Price, \$3.75.

\section{THE BRANDT SPRAYER}

A NEW DISCOVERY

The most important detall of the NEW BRANDT SPRAYER is the device for pumping the air into the tank while walking, a feature just discovered and is found in no other sprayer.

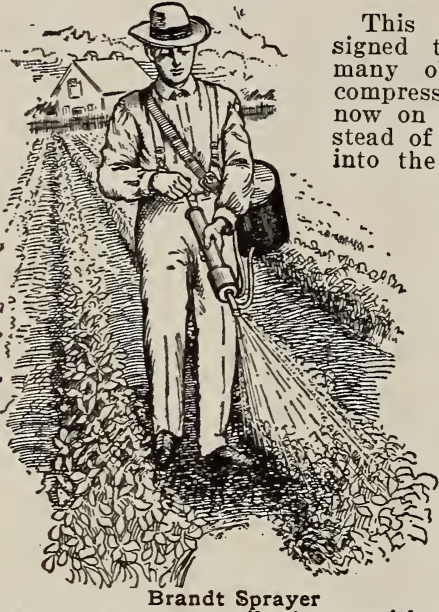

This sprayer is designed to overcome the objections to the mpressed air sprayers the market. Instead of pumping the air reservoir before starting to spray this sprayer is fitted with a pump which can be worked while you walk, thus controlling the pressure at will. Can be used for on e or two rows, and will spray from 15 to 25 hills of Potatoes with each stroke of the punap. Reservoir holds three gallons of liquid, enough to spray a row a mile long, with only one filling. The nozzles a re made on a new principle and work with a combination of liquid and air which produces more force with $7 \mathrm{lbs}$. of pressure than others do with 100 lbs., giving a fine mist-like spray which is sent out with such force that clogging is impossible.

Each

No. 2. Galvanized Tank and Shut-off Nozzle. $\$ 6.50$ No. 3. All Brass and Shut-off Nozzle....... \$.50

"Brandt Daisy" Hand Sprayer........... 1.00

"Misty" Hand Sprayer................. .50

Double Nozzles (Brass), Extra.......... 1.75

Tree Nozzles (Brass) with $3 \mathrm{ft}$. Extension

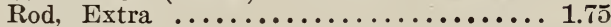

\section{LAWN SPRINKLERS Each}

Water Witch, with spur............\$0.75

The California. 3 -arm............. 1.25

Twin Comet. Revolving Nozzle........ 5.00

\section{AND GARDEN TOOLS}

The "Fire-Fly" Garden Plow

This tool is most useful in small gardens, opening furrows for manure or seeds, and covering them quickly. Price, $\$ 2.50$.

No. 6 Planet Jr. Combined Hill and Drill Seeder, Wheel Hoe, Cultivator and Plow. Has steel-driving wheel. Price, complete, $\$ 14.00$.
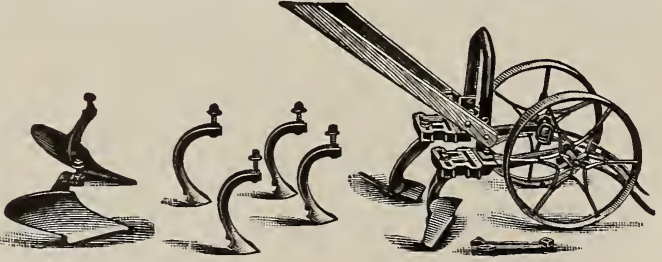


\section{BURNETT'S REINFORCED HOT BED SASH AND SUNDRIES}

\section{Single Sash, Glazed $-3 \times 6 \times 1 / 2$ in. Thick}

Our sash are made from 11/2" gulf cypress, glazed with double thick "A" quality glass in lights $10^{\prime \prime}$ wide, the top and bottom rails are $4^{\prime \prime}$ wide, the side stiles $21 / 2^{\prime \prime}$ wide and the bars $11 / 4^{\prime \prime}$. The bars are tenoned at both ends and mortised into the rails and the rails into the side stiles; the tenons are steeped in oxide of iron and oil

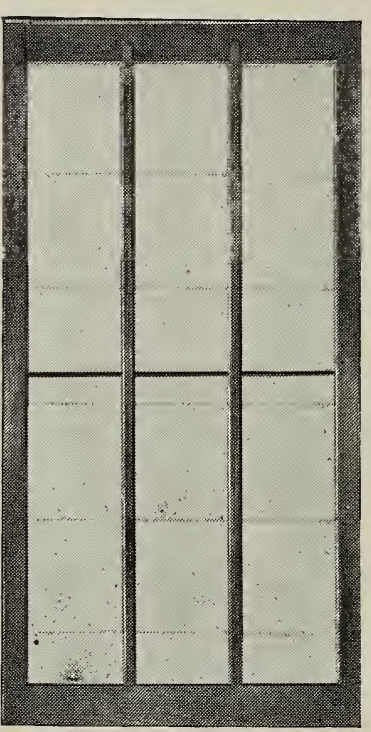

before assembling. These sash are much stronger than the ordinary market sash and are tied across the center with a square iron bar, thus making the sash very rigid. They are painted two coats of white lead and oil and the glass is bedded in special greenhouse putty.

These sash weigh 40 lbs. each and are made perfect in every way.

Price, Glazed and Painted, complete. Each \$4.25, doz. $\$ 48.00$.

Price, Unglazed and Painted one coat. Each $\$ 2.00$ doz. $\$ 22.00$.

Price, Unglazed and Un pai $n$ ted. Each \$1.50, doz. $\$ 17.00$.

\section{Sash Double Glazed, Frost-Proof}

The general opinion of gardeners who have given Double Glazed Sash a fair trial is that it has a considerable advantage over single glazed, as it will protect the plants in cold weather without the use of mats and shutters. In climates like New York and vicinity it is, however, necessary to use mats and shutters during the more severe weather. We believe that the bedding of the outer glass in putty is a decided advantage, as it makes the sash leak-tight. Aside from the double glazing these sash are made identically the same as our reinforced Single Glazed Sash.

Price, Glazed and Painted. Each \$5.00, doz. $\$ 55.00$.

\section{Cypress Slats}

Slats are for shading transplanted seedlings. The hot sun of August and September is too strong for the seedlings to stand. A week of the slats and they will have thoroughly strengthened up. They are also particularly useful for pansy growing. They are 3 feet wide and 6 long. The evenly spaced strips of cypress are let into the binding cleats and clinched into position by wire nails. They keep their shape, an important point with slats. $\quad$ Price, Painted. Each $\$ 1.50$.

\section{Hot Bed Mats}

Frost-Proof, Burlap. $76 \times 76$ in. square; Each made of strong burlap cloth, filled with

wool ................. Doz. $\$ 16.00 \$ 1.50$

Waterproof Duck. Filled same as above, with waterproof duck cotton cloth on one side. Size $76 \times 76$ in ........ Doz. $\$ 22.002 .00$

\section{Burnett's Garden Frames}

All our frames are made of the finest air dried cypress. The sides and ends are held together by heavy wrought iron angle cleats. No nails are used in their construction. They are easy to put up or take down, and are made for regular standard $3 \times 6$ feet sash. They are $8^{\prime \prime}$ deep at the front $16^{\prime \prime}$ at the back. The rafters are $3 \times 3$ inches and

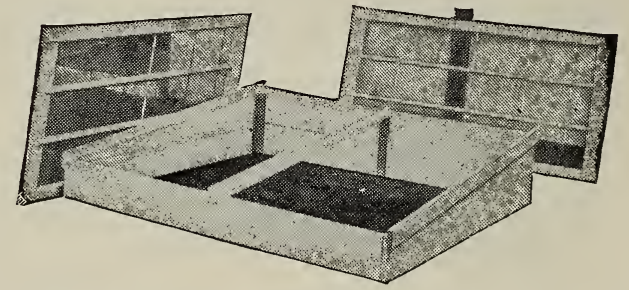

rabbeted for sash to slide on, and grooved to carry off the condensation. They are given two coats of best lead and oil before shipment. Shipped knock down. Two, three and four sash frames kept in stock-others made to order.

Price, without Sash for two Lights, $\$ 9.00$

Price, without Sash for three Lights, $\$ 10.50$.

Price, without Sash for four Lights, $\$ 12.00$.

\section{Shutters}

Shutters do three things: Keep the mats snug in place-protect them from the weather-and do their part towards keeping out the cold.

These shutters are "light to handle and stand the racket." They are 3 by 6 feet and made of $5 / 8$-inch cypress, having tight tongued and grooved joints. The three cross binders on the under side hold the boards together and prevent them warping out of shape.

Price, Painted. Each \$2.50, doz. \$25.00

Price, Unpainted. Each $\$ 2.00$, doz. $\$ 20.00$.

\section{Melon Frames}

Try a half dozen of these frames and not only have melons earlier, but melons with the true melon flavor. Starting early with frames gives them a chance to make good strong root growth

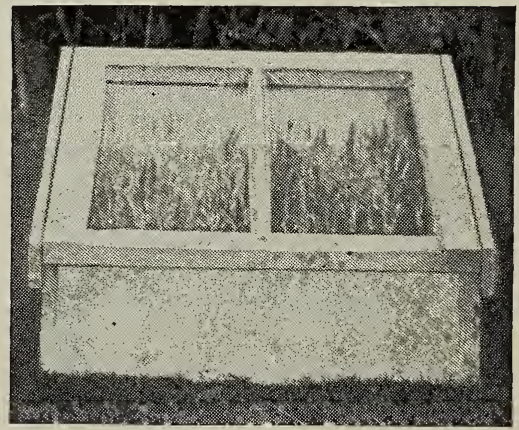

to withstand the hot Summer's sun, so the best of the plant's strength can go into the fruit. Made in the same thorough way as our other frames.

Price, Standard Size $221 / 2 \times 251 / 2$, with two Lights of glass. Each $\$ 3.00$. 


\section{INSECTICIDES, ETC.}

Ant Destroyer. A non-poisonous powder that will destroy or drive away black ants from lawns, trees, plants, etc. $1 / 4$ lb. $25 \mathrm{c} ., 1 / 2 \mathrm{lb} .40 \mathrm{c}$. lb. $75 \mathrm{c}$.

Aphis Punk. Is composed of strong nicotine, and will not injure the most sensitive blooms. Box of one dozen rolls 60c., case of 12 boxes $\$ 7.00$.

Arsenate of Lead. A poison rapidly taking the place of Paris green. Extensively used for spraying shade trees affected with the elm leaf beetle and caterpillars. The most effective remedy against the potato and rose bug. Lb. 20c., 5 lbs. 85 c., 100 lbs. $\$ 12.00$.

Bordeaux Mixture. Highly recommended for all fungoid diseases, such as mildew, leaf blight, carnation rust, etc. Qt. 50c., gal. $\$ 1.25$, 5 gals. $\$ 5.00$.

Bug Death. A non-poisonous powder, extensively used for cabbage and tomato worms, potato and cucumber bugs, etc. Lb. 15c., 3 lbs. 35c., 5 lbs. 50c., 121/2 lbs. $\$ 1.00,100$ lbs. $\$ 7.50$.

Bug Death Duster. For applying above. Eacb $25 c$.

Copper Solution. Prevents black rot, mildew, pear and apple scab, carnation and violet rust, leaf blight, etc. Qt.-tin 65c., gal. $\$ 1.50$.

Fir Tree Oil. Destroys all insects that infest fruit trees and plants, such as mealy bugs, red spider, green fly, etc. $1 / 2$ pt. $40 \mathrm{c}$., pt. $75 \mathrm{c}$., qt. $\$ 1.25,1 / 2$ gal. $\$ 2.25$, gal. $\$ 4.00$.

Fir Tree Oil Soap. Same as the above Fir Tree Oil, but prepared in soap form. 1/2-1b. tins 25c., 2 lbs. 75c.

Gishurst's Compound. A certain remedy for preventing and destroying red spider, mealy bug, green fly, etc. Box 50c.

Hammond's Grape Dust. A powder for the prevention of black rot and mildew on grapes, gooseberries, etc. 5-lb. package 35c., 10 lbs. 60c., 100 lbs. $\$ 5.00$.

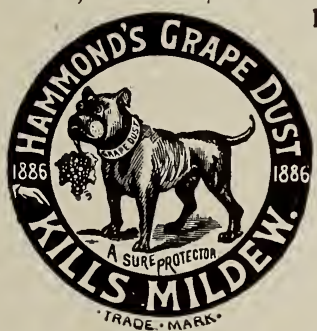

Hammond's Slug Shot. For destroying cabbage worms, potato bugs, etc. Lb.-box 15c. 5-lb. package $30 \mathrm{c} ., 10 \mathrm{lbs}$ 50c., 100 lbs. $\$ 4.50$.

Hammond's Horicum. A lime, sulphur and salt mixture, used for San José scale. One gallon makes 25 gallons for use. Qt. 40c., $1 / 2$ gal. 75 c. gal. $\$ 1.25$, 5 gals. $\$ 5.00$.

Hellebore Powder. Excellent for caterpillars, currant worms, rose slugs, etc. Box, 1/4 lb. 10c., $1 / 2$ lb. 15c., 1b. 25c.

Kerosene Emulsion. For plant lice of any kind, cabbage worms, scale insects on apple, pear and other trees. Qt. 50c., gal. \$1.25, 5 gals. $\$ 5.00$.

Lemon Oil. For destroying mealy bugs, scale, thrip, red spider, etc. $1 / 2$ pt. $25 \mathrm{c}$., pt. $40 \mathrm{c}$., qt. 75 c., $1 / 2$ gal. $\$ 1.25$, gal. $\$ 2.00$.

"Nico-Fume" Tobacco-Paper. For fumigating purposes this is the strongest TobaccoPaper offered. It will not injure the tenderest blooms. Packed in special friction-top tins and sold as follows: 24 sheets $75 \mathrm{c}$., 144 sheets $\$ 3.50,288$ sheets $\$ 6.50$.

Nico-Fume Liquid. Effective for spraying or fumigating. Does not stain or injure blooms, and leaves no disagreeable odor. $1 / 4 \mathrm{pt}$. $50 \mathrm{c}$., $1 / 2$ pt. 75 c., pt. $\$ 1.50$.

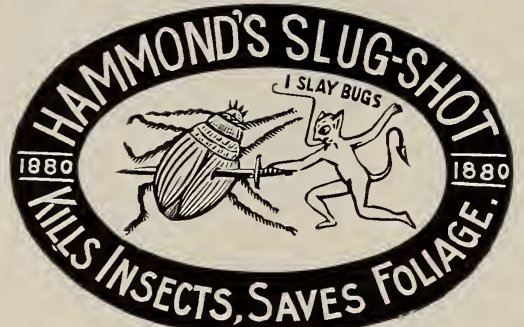

Nicoticide. Fumigating compound. A certain destroyer of all greenhouse bugs. One-pint can sufficient for 32,000 cubic feet. Each $\$ 2.50$, qt. $\$ 4.50$.

Fumigators for above. Each 75 c.

Nikoteen. A thorough exterminator of mealy bug, thrip, lice and all injurious insects. Onepint bottles. Each $\$ 1.50$.

Paris Green. Unequaled for the destruction of potato bugs and other insects. Mix $1 \mathrm{lb}$. to 200 gallons of water. Lb. 40c. (Liable to fluctuate in price.)

Read's "Herbicide" (or Weed Exterminator). One of the most effectual weed killers. Quart jugs sufficient to make 5 gallons of liquid. Price 75c., 1/2-gal. jugs \$1.25, 1-gal. kegs $\$ 2.25$, 5-gal. kegs $\$ 7.50$.

"Scalecide." The best remedy for San Jose scale. One gallon makes 20 gallons of spray. 1 -gal. cans $\$ 1.25$, 5-gal. cans $\$ 4.00,10$-gal. cans $\$ 7.50$.

Scale-Skidoo 23. The never-failing insecticide; a sure destroyer of San José ; oyster shell, cottony maple scale and all other sap-sucking insects. Directions: Dilute 1 part of ScaleSkidoo with 20 parts of water. Gal. \$1.25, 5 gals. $\$ 5.00$.

Sulphur, Powdered. Valuable for protecting against mildew on grapes, roses, etc. Lb. 10c., 10 lbs. 60c., 100 lbs. $\$ 5.00$.

Sulpho-Tobacco Soap. Will destroy rose slugs, aphides, green fly, bark lice, etc. 3-oz. box 10c., 8-oz. 20c., 10-lb. $\$ 3.00$.

Tobacco Dust (Stoothoff's). The "Black Stuff" for dusting. 50-1b. bag $\$ 2.50,100$ lbs. $\$ 4.50$.

Tobacco Dust (Stoothoff's). The Fumigating Kind. 50-lb. bag $\$ 2.50,100$ ibs. $\$ 4.50$.

Tobacco Dust. Ordinary, for dusting. Lb. 10c., 10 -lb. pkg. 65c., 100 lbs. $\$ 3.00$.

Tobacco Stems. For fumigating purposes, etc. Bales of 100 lbs. $\$ 1.75,300$ lbs. $\$ 4.50$.

Weed Killer (Eureka). Will destroy all weeds, moss, etc., on gravel walks. Large size tin, enough for 100 square yards of path. $\$ 1.00$.

Whale Oil Soap. For destroying insects. An excellent wash for all plants. Lb. 15c., 3 lbs. 40c., 5 lbs. 60c.

Wilson's Plant Oil. An excellent insecticide for house plants, particularly palms. To be used one part with four parts lukewarm water. Will remove scale and other insects with one application. Pt. 40c., qt. 75c., gal. $\$ 2.00$.

X. L. All Liquid Insecticide. An English preparation used for spraving. Pt. 65c., qt. $\$ 1.00,1 / 2$ gal. $\$ 1.75$, gal. $\$ 3.50$.

\section{Full directions how to nse printed on each can or packago.}




\section{FERTILIZERS, ETC.}

\section{Our SPECIAL GRADE Sheep Manure is the finest procurable and is certain to give satisfactory results.}

\section{BURNETT'S PULVERIZED SHEEP MANURE}

A rich, pure, natural manure. Excellent as a top-dressing for lawns. Its effect is immediate and lasting. There is nothing better for mixing with the soil for greenhouse plants-one part manure to six parts soil. It is recommended for the vegetable garden, as it promotes a steady and rapid growth. It makes a rich and safe liquid manure-1 pound to 5 gallons of water.

Special Grade, Pulverized. "Pure." Pkt. 15c. $1 / 2$ pk. 25c., pk. 50c., $100-1 b$. bag $\$ 2.50$, ton $\$ 40.00$.

Special Grade, in Cakes. "Pure," for making liquid manure. 100 -lb. bag $\$ 2.25$, ton $\$ 35.00$.

Western Brand. For top-dressing, etc. $100-1 b$ bag $\$ 2.25$, ton $\$ 35.00$.

\section{BURNETT'S LAWN DRESSING}

$A$ Perfect Food for Lawns and Golf Links

Specially prepared for lawns, as a top-dressing, giving the grass a rich green color and vigorous growth. Use 800 to 1000 pounds per acre when seeding down, and from 500 to 600 pounds per acre as a top-dressing. $5 \mathrm{lbs}$. $30 \mathrm{c}$., $10 \mathrm{lbs}$. $50 \mathrm{c}$. 50 lbs. $\$ 2.00,100$ lbs. $\$ 3.00,200$ lbs. $\$ 5.00$, ton $\$ 45.00$.

\section{ASHES, UNLEACHED}

\section{(Canada Hardwood)}

They drive away insects, and are indispensable for all crops requiring potash. They are also beneficial for garden and field crops, grass lands and lawns. Apply one to two tons per acre. In bbls. of 200 lbs. $\$ 3.00$, ton $\$ 22.00$; in bags, ton $\$ 20.00$.

\section{FINE GROUND BONE}

This fine pulverized ground bone is excellent for rose culture, top-dressing for lawns, etc. Lb. 10c. 10 lbs. 50c., 100 lbs. $\$ 2.50,200$-lb. bag $\$ 4.50$, ton $\$ 40.00$.

\section{PURE RAW GROUND BONE}

A very pure form of ground bone, especially prepared for rose culture. Also adapted for mixing with soil for potting purposes, one part bone to fifty of soil. 100 lbs. $\$ 3.00,200-1 b$. bag $\$ 5.00$, ton $\$ 45.00$

\section{CRUSHED, COARSE RAW BONE}

Excellent for graperies, etc., where more permanent results are required. 100 lbs. $\$ 3.25,200$ lb. bag $\$ 5.50$, ton $\$ 50.00$.

\section{CLAY'S CELEBRATED FERTILIZER}

One of the best manures for all horticultural purposes, either in greenhouse or garden. It is very productive and lasting, and, notwithstanding its apparently high price, is quite economical. 14 lbs. $\$ 1.25$, 28 lbs. $\$ 2.25$, 56-lb. bag $\$ 4.00,112$ lb. bag $\$ 7.00$.

\section{AGRICULTURAL SALT}

For top-dressing asparagus beds, etc. Bbl., 300 to 400 lbs., $\$ 3.00$.

\section{IMPORTED SCOTCH SOOT}

Will destroy slugs, grubs, cutworms, etc., when mixed in the surface of the soil. 100-1b. bag $\$ 5.00$.

\section{NITRATE OF SODA}

This is valuable solely for the nitrogen it contains, which is equal to 20 per cent. of ammonia It hastens the maturity of crops fully two weeks. Being extremely soluble, it should not be applied until the plants are above ground. Apply 100 to 500 pounds per acre. 5 lbs. $30 \mathrm{c}$., 10 lbs. $50 \mathrm{c}$. 50 lbs. $\$ 2.25,100$ lbs. $\$ 4.00$.

\section{BLOOD AND BONE}

Largely used for garden crops, corn, grasses, fruit trees, grape vines, etc. 100 lbs. $\$ 2.50,200$ lbs. $\$ 4.50$, ton $\$ 40.00$.

\section{THOMSON'S VINE MANURE}

A splendid fertilizer for vines and all horticultural purposes. $112-1 \mathrm{~b}$. bag $\$ 7.00$.

\section{HORN SHAVINGS}

Used for roses, chrysanthemums, etc. $100 \mathrm{lbs}$. $\$ 5.00$

\section{NEW JERSEY PEAT}

Valuable for all greenhouse plants. Bbl. $\$ 2.25$.

FIBROUS PEAT

The finest for orchids and ferns. 1-bbl. bag $\$ 2.50$

\section{LEAF MOLD}

For mixing with soil for greenhouse purposes. Bbl. $\$ 2.25$.

\section{LIVE SPHAGNUM MOSS}

For potting orchids and other stove plants. Bbl. \$3.50.

\section{SPHAGNUM MOSS}

Useful for mixing in soil for potting, also packing, etc. Bbl. $\$ 2.00,5$-bbl. bales $\$ 5.00$.

\section{PERUVIAN PLANT FOOD}

Guaranteed to contain all the necessary elements to keep house plants in a healthy and thriving condition. Small pkt. 15c., large 25c.

\section{MAPES' FERTILIZERS}

The highest grade commercial fertilizers offered, their basis being bone, no rock being used in their composition.

Potato Manure. For potatoes, asparagus, tomatoes, etc. Use three bags per acre. Bag (200 lbs.) $\$ 5.00$, ton $\$ 46.00$.

Vegetable Manure (for all soils). Good for onions, asparagus, melons, tomatoes, wheat and grass. Bag (200 lbs.) $\$ 5.50$, ton $\$ 50.00$.

Complete Manure (for general use). For use on all crops and all soils with or without stable manure. Bag (200 lbs.) $\$ 5.00$, ton $\$ 48.00$.

Complete Manure ("A" brand). Special for peas, beans, buckwheat and turnips. Bag (200 lbs.) $\$ 4.50$, ton $\$ 45.00$.

Fruit and Vine Manure. For insuring fruiting power and superior quality of fruit in vineyards (grapes), pears, apples, plums, strawberries and all small fruits. Bag (200 lbs.) $\$ 5.50$, ton $\$ 50.00$. 


\section{"STANDARD" FLOWER POTS The Advantages of Standard Pots:}

FIRST-Uniform sizes throughout the country.

SECOND-Breakage is not one-half as great as in other pots, the deep rim protecting them from any ordinary hard usage.

THIRD-The foot keeps the pot up from the bench, so that it is impossible for the hole to become clogged.

All Standard Pots from 7 -inch and above are provided with the patent Excelsior bottom which insures perfect drainage.

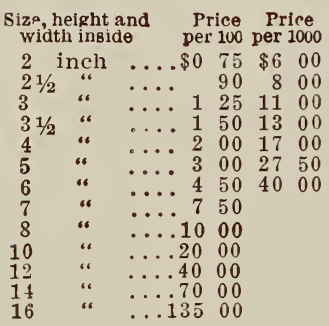

STANDARD FLOWER POTS

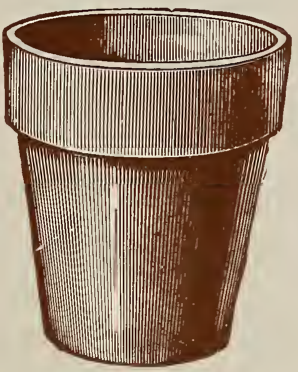

\section{SQUARE SEED PANS}
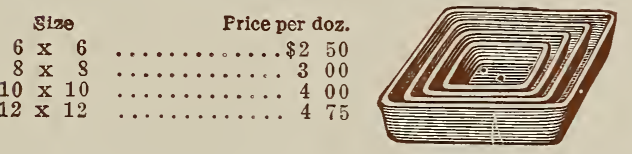

\section{ROUND BULB PANS}
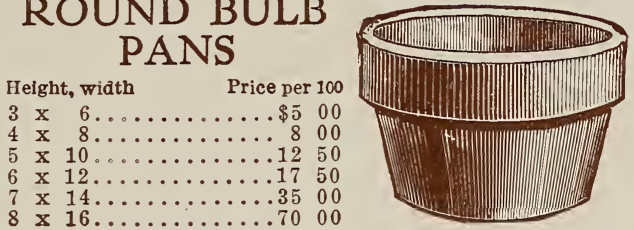

\section{ROUND FERN PANS}

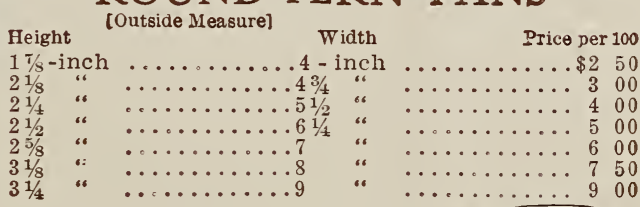

\section{AZALEA POTS}

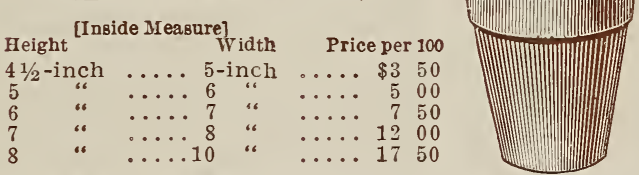

We pay particular attention to the selection and packing of these goods, but will nct be responsible for breakage in transit. We also deliver, free, to any transportation company in the city

\section{Flower Vases}

Indurated Wood Fibre F'or Displaying Cut Flowers

Will not leak or rust. Plain cherry color.

No. 0,8 in. diam., 13 in. deep, per doz., $\$ 7.00$.

No. $1,5 \frac{1}{2}$ in. diam., 10 in. deep, per doz., $\$ 6.00$.

No. $2,4 \frac{1}{2}$ in. diam., 9 in deep, per doz., $\$ 5.00$.

No. 3,4 in. diam., 6 in deep, per doz., $\$ 4.50$.

No. 4,3 in. diam., $41 / 2$ i
deep, per doz., $\$ 4.00$.

No. 00,9 in. diam., 22 in.

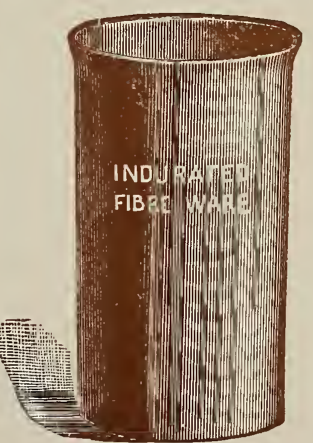

\section{Flower Pot Saucers}

\section{Indurated Wood Fibre}

Very light and durable. Not porous, and will protect tables on which the plants stand.
Size

Each Perdoz Size

$\ldots \ldots \$ 010$ \$1 00

$\begin{array}{lll}\ldots \ldots & 12 & 125 \\ \ldots \ldots & 13 & 135\end{array}$

10 in

$\ldots \ldots \$ 0_{20}^{\text {Each Per doz }}$

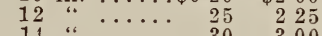

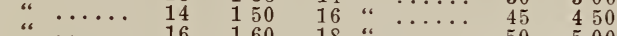

Union Pattern Plant Tubs

These Tubs are made of he a v y cypress, staves 1 inch thick, $\mathrm{p}$ a i $\mathrm{n}$ t e d green, with iron hoops, $f$ e $t$ a $n d$ h a $\mathrm{n}$ d 1 e $\mathrm{s}$ bottoms per forated.

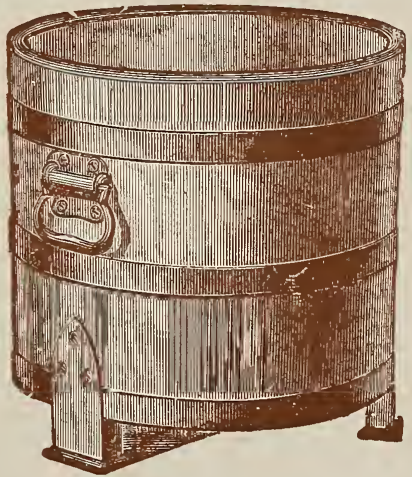

No. Height Outsid 3 Diam.Top Diam. Bottom Each

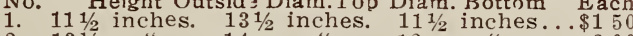

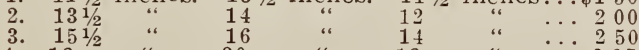

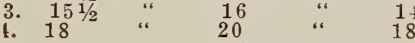
5. 20

\section{New York Plant Tubs}

Made of selected Virginia White Cedar, painted green, with hoops, handles and leg castings painted black. The bottoms are perforated and removable.

Height Diam. Each No. 1.22 in. 25 in... $\$ 600$

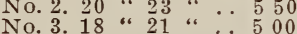
No. 4.16 “ 18 “ $\ldots 450$
Height Diam. Each No. 14 in. 16 in... $\$ 400$ No. 7.11 " 13 “ 13.300 No. 8. 10 " 12 “ $\because 250$ 

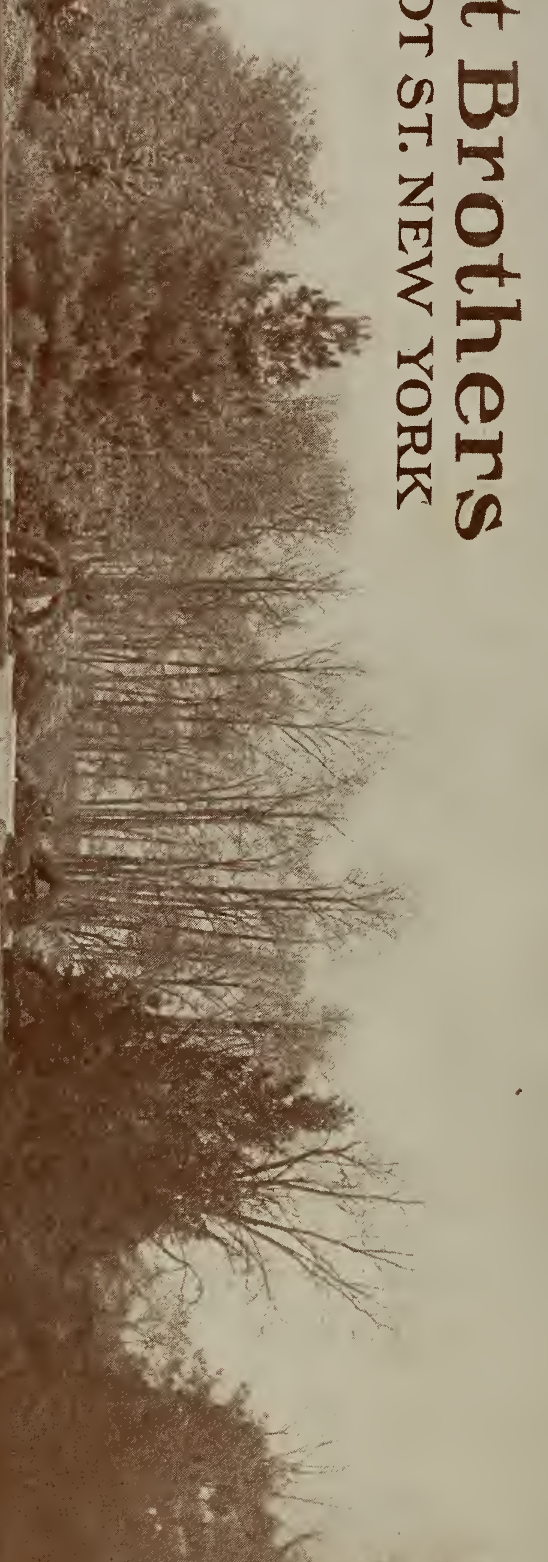